Prepared in cooperation with the Silver Lake Improvement Board

\title{
Water Quality and Hydrology of Silver Lake, Oceana County, Michigan, with Emphasis on Lake Response to Nutrient Loading, 2012-14
}

Scientific Investigations Report 2015-5158 
Cover photograph. Silver Lake, Oceana County, Michigan, taken by Jim Nicholas. 


\section{Water Quality and Hydrology of Silver Lake, Oceana County, Michigan, with Emphasis on Lake Response to Nutrient Loading, 2012-14}

By Angela K. Brennan, Christopher J. Hoard, Joseph W. Duris, Mary E. Ogdahl, and Alan D. Steinman

Prepared in cooperation with the Silver Lake Improvement Board

Scientific Investigations Report 2015-5158 


\title{
U.S. Department of the Interior SALLY JEWELL, Secretary
}

\section{U.S. Geological Survey Suzette M. Kimball, Director}

\author{
U.S. Geological Survey, Reston, Virginia: 2016
}

For more information on the USGS - the Federal source for science about the Earth, its natural and living resources, natural hazards, and the environment—visit http://www.usgs.gov or call 1-888-ASK-USGS.

For an overview of USGS information products, including maps, imagery, and publications, visit http://www.usgs.gov/pubprod/.

Any use of trade, firm, or product names is for descriptive purposes only and does not imply endorsement by the U.S. Government.

Although this information product, for the most part, is in the public domain, it also may contain copyrighted materials as noted in the text. Permission to reproduce copyrighted items must be secured from the copyright owner.

Suggested citation:

Brennan, A.K., Hoard, C.J., Duris, J.W., Ogdahl, M.E., and Steinman, A.D., 2015, Water quality and hydrology of Silver Lake, Oceana County, Michigan, with Emphasis on lake response to nutrient loading, 2012-14. U.S. Geological Survey Scientific Investigations Report 2015-5158, 75 p., http://dx.doi.org/10.3133/sir20155158.

ISSN 2328-031X (print)

ISSN 2328-0328 (online) 


\section{Acknowledgments}

The project partners on this study include the U.S. Geological Survey (USGS)-Michigan Water

Science Center; the Annis Water Resources Institute-Grand Valley State University (AWRI-GVSU); and Progressive AE. The project coordinators were members of the Silver Lake Improvement Board. The authors thank all the following who worked hard to make the project successful.

Silver Lake Project Steering Committee

Anthony Groves, Progressive AE, Grand Rapids, Michigan

Larry Byl, Oceana County Commissioner, Shelby, Mich.

William DeJong, Silver Lake property owner, Mears, Mich.

Bill Bryker, Silver Lake property owner, Mears, Mich.

Ed DeJong, Silver Lake property owner, Mears, Mich.

Marc DeMatt, Silver Lake property owner, Mears, Mich.

Project Volunteers

Marc DeMatt, Silver Lake property owner/Silver Creek Dam Operator, Mears, Mich.

Susan Sharp, Friends of Silver Lake/Silver Lake property owner, Mears, Mich.

Chuck Persenaire, Silver Lake property owner, Mears, Mich.

Silver Lake State Park, Michigan Department of Natural Resources, Mears, Mich.

Data Collection and Web site Design

Thomas Morgan, Hydrologic Technician, USGS, Lansing, Mich.

Charles Taricska, Hydrologic Technician, USGS, Lansing, Mich.

Joshua Loewel, Hydrologic Technician, USGS, Lansing, Mich.

Ryan Oster, Microbiologist, formerly with USGS, Lansing, Mich.

Julia Giesen, Hydrologist, USGS, Lansing, Mich.

Marie Reynolds, Information Technology Specialist, USGS, Lansing, Mich.

Maggie Weinert, AWRI-GVSU, Muskegon, Mich.

Kurt Thompson, AWRI-GVSU, Muskegon, Mich.

James Smit, AWRI-GVSU, Muskegon, Mich.

Brian Scull, AWRI-GVSU, Muskegon, Mich.

Technical Reviewers

Howard Reeves, Research Hydrologist, USGS, Lansing, Mich.

Angela Crain, Hydrologist, USGS, Louisville, Kentucky 



\section{Contents}

Acknowledgments .........................................................................................................ii

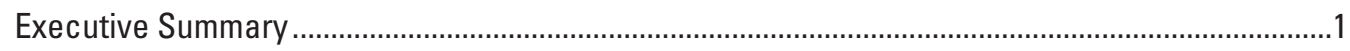

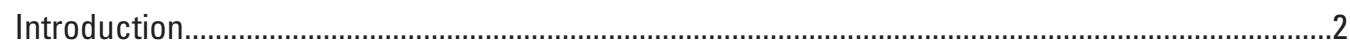

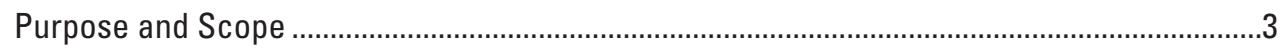

Silver Lake and Surrounding Watershed ...............................................................................

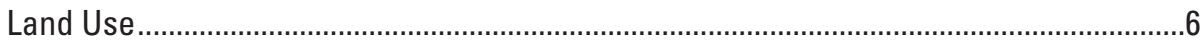

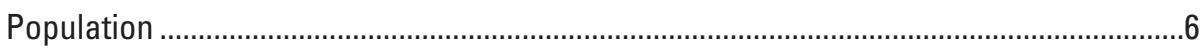

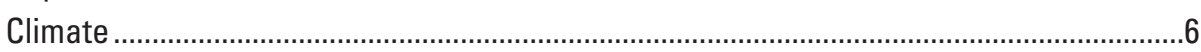

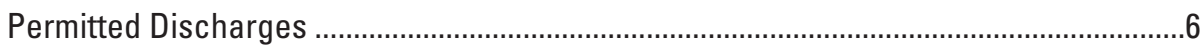

History of Monitoring on Silver Lake ....................................................................................

Silver Lake-2011 Water Quality Monitoring Report, Progressive AE................................8

A Pilot Study: Silver Lake Water Quality-Michigan State University ................................8

Silver Lake Water Quality and Watershed Management Study, 2001-Water Quality

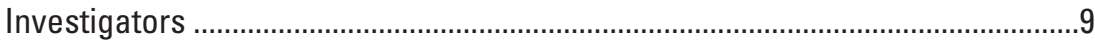

Friends of Silver Lake Monitoring .................................................................................

Michigan Cooperative Lakes Monitoring Program .......................................................

Water Quality Characteristics of Michigan's Inland Lakes, 2001-10-USGS/MDE0.........9

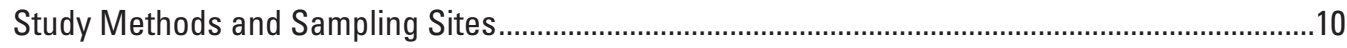

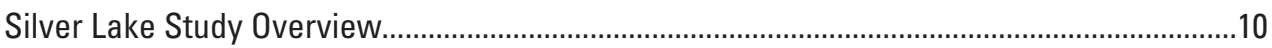

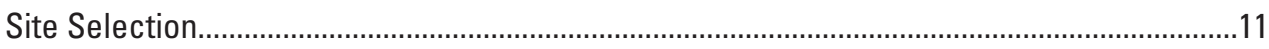

Water-Quality Data Collection .................................................................................................. 11

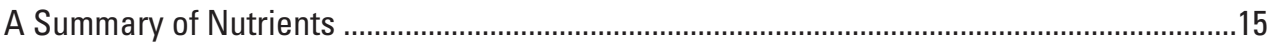

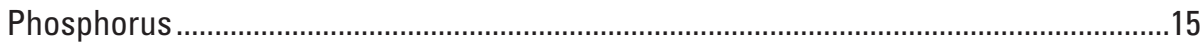

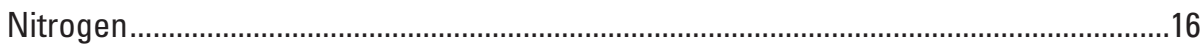

Lake Monitoring …................................................................................................

Internal Nutrient Loading .............................................................................17

Diel Dissolved Oxygen Measurements ...............................................................18

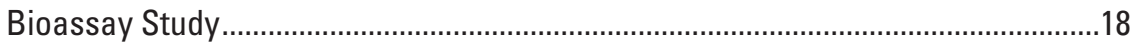

Tributary Monitoring and Streamgaging ..................................................................19

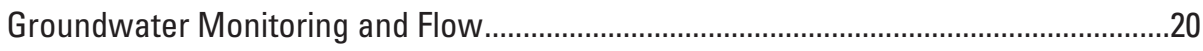

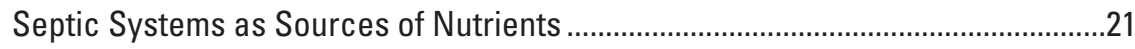

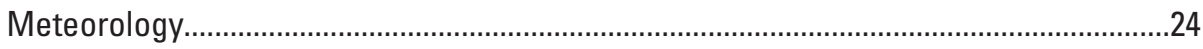

Atmospheric Deposition Monitoring ……………………….........................................24

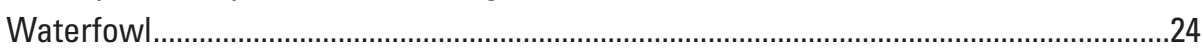

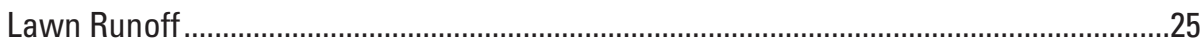

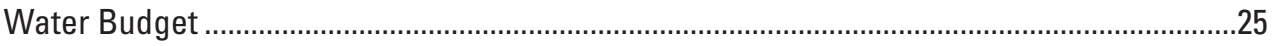

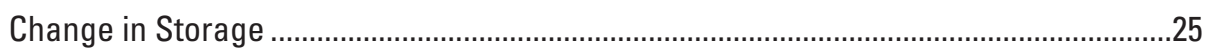

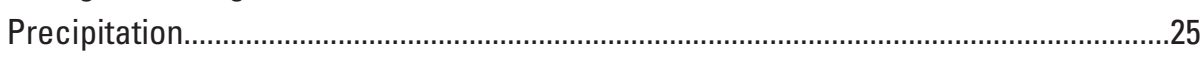

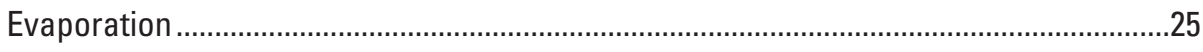

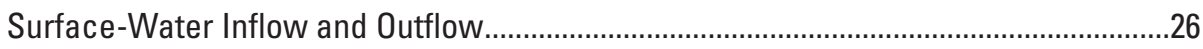

Groundwater Inflow and Outflow (Flux) ..............................................................26 
Laboratory Analysis

U.S. Geological Survey National Water-Quality Laboratory/ U.S. Geological Survey

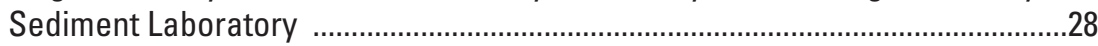

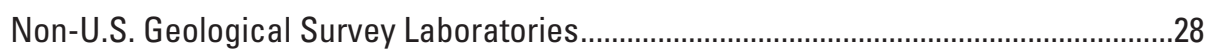

Internal Nutrient Loading ....................................................................................

Sediment Metal Analysis.......................................................................................

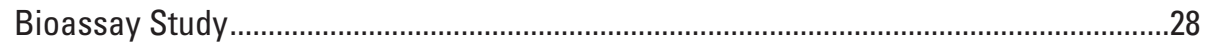

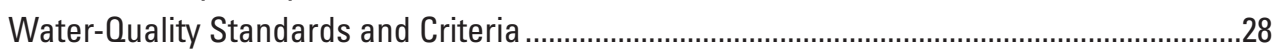

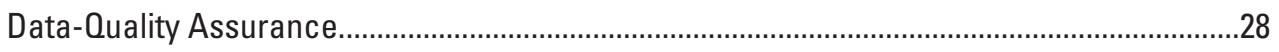

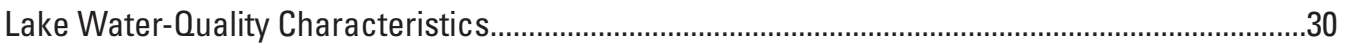

Trophic Status and Lake Classification ..............................................................................33

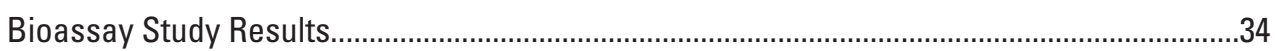

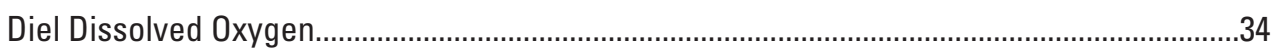

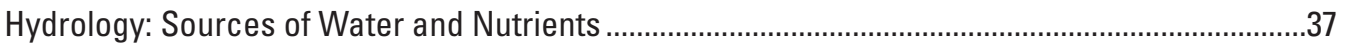

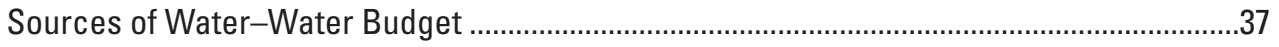

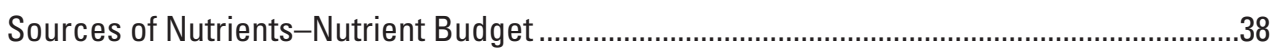

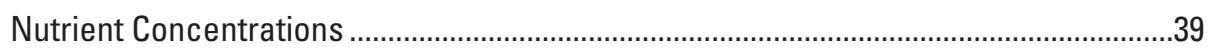

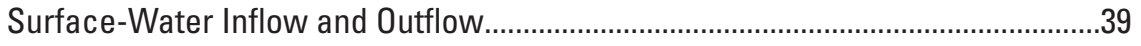

Precipitation and Dry Deposition ........................................................................

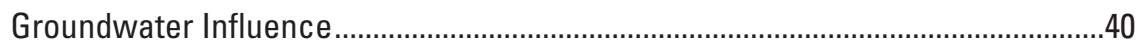

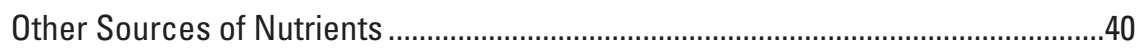

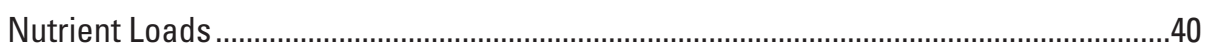

Surface-Water Inflow and Outflow......................................................................40

Precipitation and Dry Deposition ..........................................................................42

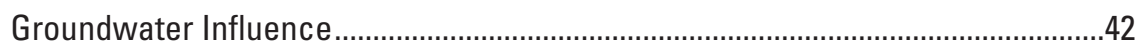

Internal Nutrient Loading ...............................................................................42

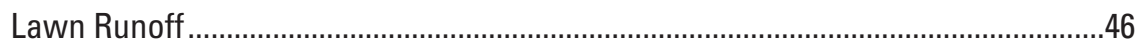

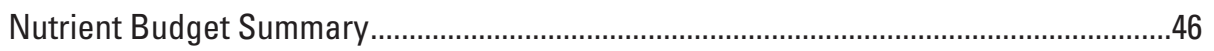

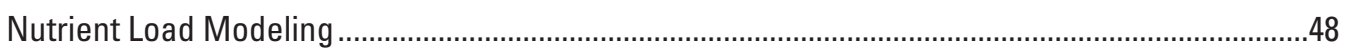

BATHTUB Data Requirements and Limitations................................................................4

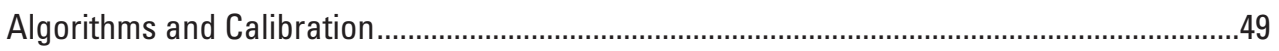

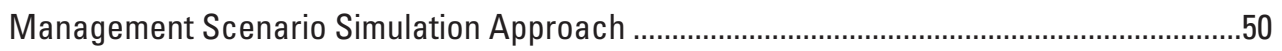

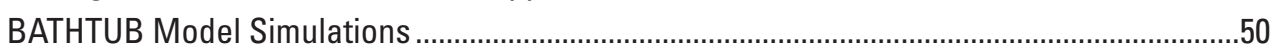

Nutrient Loading Scenarios ................................................................................50

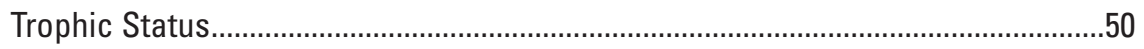

Changes in Percentage of Days with Algal Blooms ……......................................52

Reduced Septic Input to Silver Lake .................................................................52

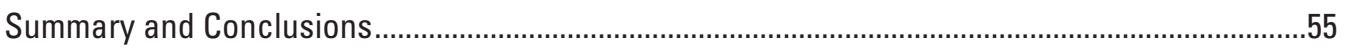

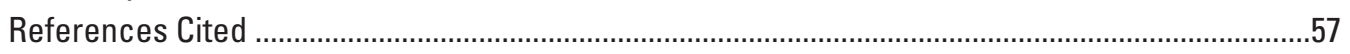

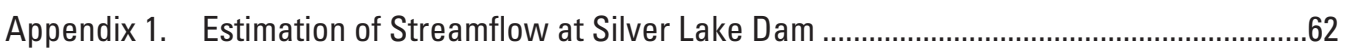

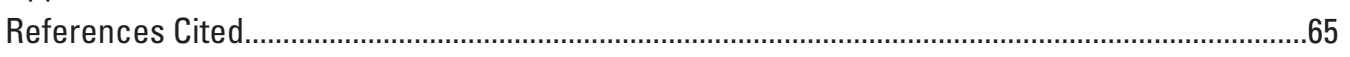

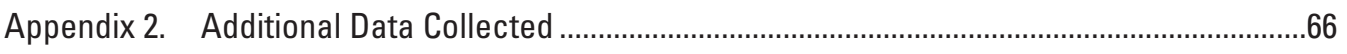

Bioassay Study-Microcystin and Phytoplankton ..............................................................66

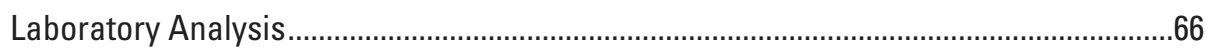

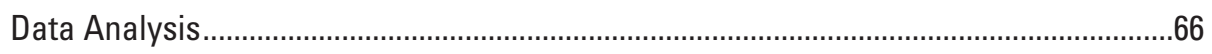

Bioassay Study Results-Microcystin and Phytoplankton ................................................66 


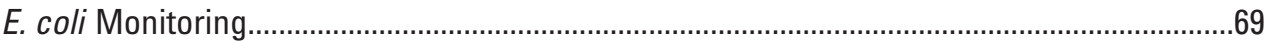

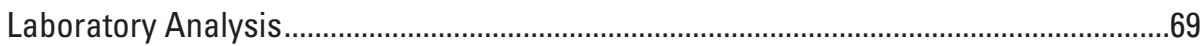

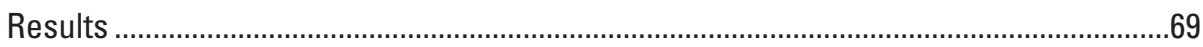

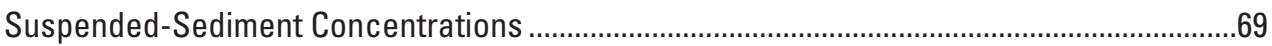

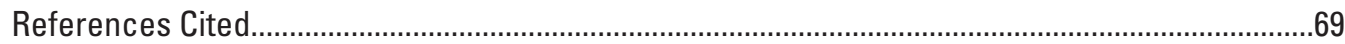

Appendix 3. Quantification of Groundwater Flow to Silver Lake..............................................70

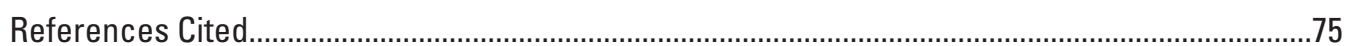

\section{Figures}

1. Map showing Silver Lake watershed delineation and land-use classifications, Oceana County, Michigan........................................................................

2. Map showing Silver Lake sampling locations, Oceana County, Michigan..........................5

3. Schematic overview of study in Silver Lake Oceana County, Michigan..........................10

4. Schematic diagram showing the phosphorus cycle in lakes .........................................15

5. Schematic diagram showing the nitrogen cycle in lakes...............................................16

6. Photographs of bioassay carboys $(A)$ prior to final subsampling at the end of the incubation period, and bioassay incubation frame $(B)$ at its deployment location at the north end of Silver Lake, Oceana County, Michigan.................................19

7. Graph showing the total nitrogen and total phosphorus concentrations measured in Silver Lake Oceana County, Michigan, 2012 to 2014.....................................31

8. Graph showing nitrogen to phosphorus ratios in Silver Lake, Oceana County, Michigan, 2012 to 2014.......................................................................................32

9. Bar graph showing the trophic status of Silver Lake, Oceana County, Michigan, based on Carlson's Trophic State Index..

10. Bar graph showing mean (plus or minus standard deviation) chlorophyll a concentrations from the four bioassay treatments

11. Graph series showing diel dissolved oxygen (DO) and wind data from the south (L5) and middle (L2) monitoring stations on Silver Lake, Oceana County, Michigan, on four dates in 2013.

12. Pie diagrams showing the annual water budget for Silver Lake, Oceana County, Michigan...

13. Pie diagrams showing the water budget, by season, for Silver Lake, Oceana County, Michigan.....

14. Pie diagrams showing mean nutrient loading, by season, to Silver Lake, Oceana County, Michigan...

15. Graphs showing percentage of modeled septic contribution to total nutrient load in Silver Lake, Oceana County, Michigan, estimated using BATHTUB.

16. Graph showing total phosphorus concentrations released/retained from sediment into the water column for oxic ( $0 x)$ and anoxic $(A n)$ treatments

17. Graph showing ammonium concentrations released/retained from sediment into the water column for oxic (Ox) and anoxic (An) treatments.

18. Bar graph showing total phosphorus concentrations in sediment (upper 5 centimeters) at the two internal loading study locations in Silver Lake, Oceana County, Michigan, on each core collection date..

19. Pie diagrams showing annual phosphorus and nitrogen budget summaries for Silver Lake, Oceana County, Michigan. 


\section{Figures-Continued}

20. Bar graphs showing summary of nutrient loading scenarios using the

BATHTUB model for Silver Lake, Oceana County, Michigan ..

21. Bar graphs showing the simulated effect of conversion from onsite septic-waste treatment (within 200 feet of shoreline) to central sewer system using BATHTUB

1-1. Schematic diagram of the approximate dam configuration for the Silver Lake Dam at Silver Creek, Oceana County, Michigan.

1-2. Graph showing the discharge rating for Silver Creek Dam, Oceana County, Michigan

2-1. Barplots (mean plus 1 standard error) of phytoplankton biovolume in Silver Lake, Oceana County, Michigan, for five nutrient treatments.

3-1. Graph showing continuous and discrete water-level elevations for the shallow wells around Silver Lake, Oceana County, Michigan, April 2013-December 2014.

3-2. Map showing locations of piezometers, seepage meters, and temperature sensor array deployments around Silver Lake, Oceana County, Michigan.

3-3. Graph series showing the comparison of simulated to observed temperature values at 3.9 and 7.9 inches in depth for the east, north, and south temperature arrays deployed at Silver Lake, Oceana County, Michigan

\section{Tables}

1. Historical and current water-quality studies for Silver Lake, Oceana County, Michigan, and associated analytes.

2. Nutrient study sampling locations and sampling strategy for Silver Lake, Oceana County, Michigan

3. Analytes measured as part of the 2012-14 nutrient loading study for

Silver Lake, Oceana County, Michigan ...

4. Septic contribution model input

5. References for Michigan water-quality nutrient criteria recommendations for lakes and rivers..

6. Statistical summary of nutrient and chlorophyll a concentrations measured from 2012-14 nutrient study in Silver Lake, Oceana County, Michigan .

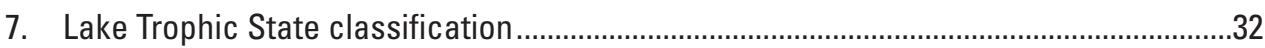

8. Nutrient loading from groundwater to Silver Lake, Oceana County, Michigan ..............42

9. Mean and standard deviation (SD) of total phosphorus (TP) and ammonium (NH4+) flux, in milligrams per squaremeter per day, from sediment cores collected from Silver Lake, Oceana County, Michigan, and incubated for 28 days

10. Summary of septic-load estimates to Silver Lake, Oceana County, Michigan, using the septic model

11. Model algorithms selected when running BATHTUB simulations for Silver Lake, Oceana County, Michigan .

12. Nutrient concentration adjustment scenarios simulated using the BATHTUB model. 


\section{Tables-Continued}

13. Simulated algal bloom frequency for Silver Lake, Oceana County, Michigan, in response to changes in phosphorus and nitrogen loading scenarios ...........................53

1-1. List of adjustments made to dam configuration during this study ..................................63

2-1. Ten most abundant phytoplankton species based on frequency of occurrence ............67 


\section{Conversion Factors}

[Inch/Pound to International System of Units[

\begin{tabular}{|c|c|c|}
\hline Multiply & By & To obtain \\
\hline \multicolumn{3}{|c|}{ Length } \\
\hline inch (in.) & 25.4 & millimeter (mm) \\
\hline foot $(\mathrm{ft})$ & 0.3048 & meter $(\mathrm{m})$ \\
\hline mile (mi) & 1.609 & kilometer (km) \\
\hline yard (yd) & 0.9144 & meter $(\mathrm{m})$ \\
\hline \multicolumn{3}{|c|}{ Area } \\
\hline acre & 4,047 & square meter $\left(\mathrm{m}^{2}\right)$ \\
\hline acre & 0.004047 & square kilometer $\left(\mathrm{km}^{2}\right)$ \\
\hline square foot $\left(\mathrm{ft}^{2}\right)$ & 0.09290 & square meter $\left(\mathrm{m}^{2}\right)$ \\
\hline square mile $\left(\mathrm{mi}^{2}\right)$ & 259.0 & hectare (ha) \\
\hline square mile $\left(\mathrm{mi}^{2}\right)$ & 2.590 & square kilometer $\left(\mathrm{km}^{2}\right)$ \\
\hline \multicolumn{3}{|c|}{ Volume } \\
\hline cubic inch $\left(\right.$ in $\left.^{3}\right)$ & 16.39 & cubic centimeter $\left(\mathrm{cm}^{3}\right)$ \\
\hline cubic inch $\left(\right.$ in $\left.^{3}\right)$ & 0.01639 & liter (L) \\
\hline cubic foot $\left(\mathrm{ft}^{3}\right)$ & 0.02832 & cubic meter $\left(\mathrm{m}^{3}\right)$ \\
\hline cubic yard $\left(\mathrm{yd}^{3}\right)$ & 0.7646 & cubic meter $\left(\mathrm{m}^{3}\right)$ \\
\hline cubic mile $\left(\mathrm{mi}^{3}\right)$ & 4.168 & cubic kilometer $\left(\mathrm{km}^{3}\right)$ \\
\hline acre-foot (acre-ft) & 1,233 & cubic meter $\left(\mathrm{m}^{3}\right)$ \\
\hline acre-foot (acre-ft) & 0.001233 & cubic hectometer $\left(\mathrm{hm}^{3}\right)$ \\
\hline \multicolumn{3}{|c|}{ Flow rate } \\
\hline acre-foot per day (acre-ft/d) & 0.01427 & cubic meter per second $\left(\mathrm{m}^{3} / \mathrm{s}\right)$ \\
\hline acre-foot per year (acre-ft/yr) & 1,233 & cubic meter per year $\left(\mathrm{m}^{3} / \mathrm{yr}\right)$ \\
\hline foot per second (ft/s) & 0.3048 & meter per second $(\mathrm{m} / \mathrm{s})$ \\
\hline cubic foot per second $\left(\mathrm{ft}^{3} / \mathrm{s}\right)$ & 0.02832 & cubic meter per second $\left(\mathrm{m}^{3} / \mathrm{s}\right)$ \\
\hline $\begin{array}{l}\text { cubic foot per second per square } \\
\text { mile }\left[\left(\mathrm{ft}^{3} / \mathrm{s}\right) / \mathrm{mi}^{2}\right]\end{array}$ & 0.01093 & $\begin{array}{l}\text { cubic meter per second per } \\
\text { square kilometer }\left[\left(\mathrm{m}^{3} / \mathrm{s}\right) / \mathrm{km}^{2}\right]\end{array}$ \\
\hline cubic foot per day $\left(\mathrm{ft}^{3} / \mathrm{d}\right)$ & 0.02832 & cubic meter per day $\left(\mathrm{m}^{3} / \mathrm{d}\right)$ \\
\hline gallon per day (gal/d) & 0.003785 & cubic meter per day $\left(\mathrm{m}^{3} / \mathrm{d}\right)$ \\
\hline million gallons per day (Mgal/d) & 0.04381 & cubic meter per second $\left(\mathrm{m}^{3} / \mathrm{s}\right)$ \\
\hline $\begin{array}{l}\text { million gallons per day per square } \\
\text { mile }\left[(\mathrm{Mgal} / \mathrm{d}) / \mathrm{mi}^{2}\right]\end{array}$ & 1,461 & $\begin{array}{l}\text { cubic meter per day per square } \\
\text { kilometer }\left[\left(\mathrm{m}^{3} / \mathrm{d}\right) / \mathrm{km}^{2}\right]\end{array}$ \\
\hline inch per year (in/yr) & 25.4 & millimeter per year $(\mathrm{mm} / \mathrm{yr})$ \\
\hline \multicolumn{3}{|c|}{ Mass } \\
\hline ounce, avoirdupois (oz) & 28.35 & gram $(\mathrm{g})$ \\
\hline pound, avoirdupois (lb) & 0.4536 & kilogram (kg) \\
\hline
\end{tabular}

Temperature in degrees Celsius $\left({ }^{\circ} \mathrm{C}\right)$ may be converted to degrees Fahrenheit $\left({ }^{\circ} \mathrm{F}\right)$ as:

$$
{ }^{\circ} \mathrm{F}=\left(1.8 \times{ }^{\circ} \mathrm{C}\right)+32 .
$$

Temperature in degrees Fahrenheit $\left({ }^{\circ} \mathrm{F}\right)$ may be converted to degrees Celsius $\left({ }^{\circ} \mathrm{C}\right)$ as:

$$
{ }^{\circ} \mathrm{C}=\left({ }^{\circ} \mathrm{F}-32\right) / 1.8 \text {. }
$$

Micron is a unit of length equal to one millionth of a meter. 


\section{Datum}

Vertical coordinate information is referenced to the North American Vertical Datum of 1988

(NAVD88), and National Geodetic Vertical Datum of 1929 (NGVD29)

Horizontal coordinate information is referenced to the North American Datum of 1983 (NAD83), and North American Datum of 1927 (NAD27).

Altitude, as used in this report, refers to distance above the vertical datum.

\section{Abbreviations}

\begin{tabular}{ll} 
ADV & acoustic doppler velocimeter \\
ADVM & acoustic doppler velocity meter \\
ANOSIM & analysis of similarity \\
ANOVA & analysis of variance \\
AWRI & Annis Water Resources Institute \\
BMPs & best management practices \\
CLMP & Cooperative Lakes Monitoring Program \\
DPP & drive-point piezometer \\
E. coli & Escherichia coli \\
EPA & U.S. Environmental Protection Agency \\
EWI & equal-width-increment \\
GPS & global positioning system \\
hrt & Hart \\
Idt & Ludington \\
LC-MS & liquid chromatography-mass spectrometry \\
MDEO & Michigan Department of Environmental Quality \\
MDNR & Michigan Department of Natural Resources \\
MI-WSC & Michigan Water Science Center \\
MJ & megajoules \\
MSU & Michigan State University \\
NCDC & National Climatic Data Center \\
\hline
\end{tabular}




\section{Abbreviations-Continued}

\begin{tabular}{ll} 
NLCD & National Land Cover Database \\
NMDS & nonmetric multidimensional scaling \\
NOAA & National Oceanic and Atmospheric Administration \\
NWIS & National Water Information System \\
NWOL & National Water Quality Laboratory \\
ORV & off-road vehicle \\
PAR & photosynthetically-active radiation \\
PCU & platinum cobalt units \\
ppm & parts per million \\
PVC & polyvinyl chloride \\
RMSE & root mean square error \\
RPD & relative percent difference \\
SD & standard deviation \\
SLIB & Silver Lake Improvement Board \\
SLSP & Silver Lake State Park \\
SRP & soluble reactive phosphorus \\
SSC & suspended sediment concentration \\
TSI & Trophic State Index \\
TDS & total dissolved solids \\
TNTC & too numerous to count \\
TSS & total suspended solids \\
USDA & U.S. Department of Agriculture \\
USGS & U.S. Geological Survey \\
UV & ultraviolet \\
WHO & World Health Organization \\
yr & year \\
\hline
\end{tabular}




\title{
Water Quality and Hydrology of Silver Lake, Oceana County, Michigan, with Emphasis on Lake Response to Nutrient Loading, 2012-14
}

\author{
By Angela K. Brennan, ${ }^{1}$ Christopher J. Hoard, ${ }^{1}$ Joseph W. Duris, ${ }^{1}$ Mary E. Ogdahl, ${ }^{2}$ and Alan D. Steinman ${ }^{2}$
}

\section{Executive Summary}

Silver Lake is a 672-acre inland lake located in Oceana County, Michigan, and is a major tourist destination due to its proximity to Lake Michigan and the surrounding outdoor recreational opportunities. In recent years, Silver Lake exhibited patterns of high phosphorus concentrations, elevated chlorophyll $a$ concentrations, and nuisance algal blooms.

The U.S. Geological Survey (USGS), in cooperation with the Silver Lake Improvement Board and in collaboration with the Annis Water Resources Institute (AWRI) of Grand Valley State University, designed a study to assess the hydrologic and nutrient inputs to Silver Lake in order to identify the events and conditions that affect the nutrient chemistry and production of algal blooms in the lake. This information can inform water-resource managers in developing various management strategies to prevent or reduce the occurrence of future algal blooms.

USGS and AWRI scientists collected data from November 2012 to December 2014 to provide information for future management decisions for Silver Lake. Silver Lake can be classified as a polymictic lake and has a residence time of approximately 223 days. Based on the mean lake Secchi depth, total phosphorus, and total nitrogen concentrations, Silver Lake is classified as a eutrophic lake. In-situ bioassay results indicate that algal growth in Silver Lake is colimited by both nitrogen and phosphorus. The nutrient budget for Silver Lake was calculated using the BATHTUB model based on 2 years of water-quality data collection. The BATHTUB model, developed by the U.S. Army Corps of Engineers, treats the lake as a well-mixed system with multiple inputs and outlets for both water and dissolved constituents, such as nutrients.

Based on results of the BATHTUB model, which were conditioned on observed concentrations and flows, the mean annual input of phosphorus to Silver Lake was approximately 1,342 pounds (lb); the mean annual input of nitrogen to Silver

\footnotetext{
${ }^{1}$ U.S. Geological Survey, Michigan Water Science Center, Lansing, Michigan

${ }^{2}$ Annis Water Resources Institute, Grand Valley State University, Muskegon, Michigan
}

Lake was approximately $51,998 \mathrm{lb}$. The major measured sources of phosphorus loading to Silver Lake were groundwater and Hunter Creek, whereas the major measured sources of nitrogen to Silver Lake were Hunter Creek, groundwater, and atmospheric deposition. The largest loading of phosphorus and nitrogen to Silver Lake occurred during the spring. Minimal phosphorus deposition (if any) occurred in the lakebed sediment; however, of the nitrogen that entered Silver Lake, approximately 42.2 percent was deposited in the lakebed sediment as simulated by the BATHTUB model.

In addition to measured sources, a septic load model was used to estimate the likely range of septic contribution to groundwater and adjacent surface waters. The likely septic loading scenario estimates that septic systems contribute 47.8 percent of the phosphorus to groundwater and 22.3 percent of phosphorus to Hunter Creek. These results indicate that septic systems are a major source of phosphorus loading to Silver Lake. The likely septic loading scenario indicated that septic systems account for 0.95 percent of the nitrogen load to Hunter Creek and 1.1 percent of the contribution of nitrogen to groundwater.

The BATHTUB model was used to estimate future nutrient loading and eutrophication scenarios based on waterquality data collected from Silver Lake, groundwater, major tributaries, and atmospheric deposition. A separate septic load model was used to estimate the septic contribution to groundwater or directly to surface water, and the nutrient load estimates were modeled using the BATHTUB model to determine subsequent water-quality changes to Silver Lake.

- BATHTUB model scenarios based on measured data:

- The first BATHTUB scenario evaluated the condition of Silver Lake and the change to lake water quality (trophic status) as a result of changes in nutrient loading from different sources. Based on BATHTUB model simulations, if groundwater loading of phosphorus and nitrogen only were decreased by 75 percent, and all of the other nutrient inputs stayed the same, the future condition of Silver Lake would most likely remain highly mesotrophic to 
eutrophic (the current [2014] condition of Silver Lake). If nutrient loading continued to increase in groundwater, the lake would continue to remain eutrophic with more frequent algal blooms. If nutrient loading from Hunter Creek only decreased by 50-75 percent, and all of the other nutrient inputs stayed the same as the baseline dataset, Silver Lake would remain eutrophic to highly mesotrophic. By reducing the input of manageable nutrient sources (Hunter Creek, groundwater, and lawn runoff) by 75 percent, the BATHTUB model simulation indicates that Silver Lake would be classified as mesotrophic, which is indicative of improved water quality, water clarity, and reduced algal bloom frequency.

- Simulations also were run using the BATHTUB model to evaluate the number of days Silver Lake could experience algal blooms (algal blooms are defined as modeled chlorophyll $a$ in excess of 10 micrograms per liter $[\mu \mathrm{g} / \mathrm{L}]$ ) as a result of an increase/decrease in phosphorus and nitrogen loading from groundwater, Hunter Creek, and (or) a combination of sources. If the phosphorus and nitrogen loading from Hunter Creek is decreased (and all other sources are not altered), Silver Lake will continue to experience algal blooms, but less frequently than what is currently experienced. The same scenario holds true if the nutrient loading from groundwater is decreased. Another scenario was simulated using a combination of sources, which includes increases and decreases in phosphorus and nitrogen loading from sources that are the most likely to be managed, and includes groundwater (as a result of conversion of household septic to sewers), Hunter Creek (conversion of household septic to sewers), and lawn runoff. Results of the BATHTUB model indicated that a 50-percent reduction of phosphorus and nitrogen from these sources would result in a considerable decrease in algal bloom frequency (from 231 to 132 days) and severity, and a 75-percent reduction would greatly reduce algal bloom occurrence on Silver Lake (from 231 to 57 days).

- BATHTUB model scenarios based on septic load model:

- A scenario also was conducted using the BATHTUB model to simulate the conversion of septic to sewer and included a low, high, and medium (likely) scenario of nutrient loading to Silver Lake. Simulations of the BATHTUB model indicated that, under the likely scenario, the conversion of all onsite septic treatment to sewers would result in an overall change in lake trophic status from eutrophic to mesotrophic, thereby reducing the frequency of algal blooms and algal bloom intensity on Silver Lake (chlorophyll $a$ $>10 \mu \mathrm{g} / \mathrm{L}$, from 231 to 184 days per year, or chlorophyll $a>20 \mu \mathrm{g} / \mathrm{L}$, from 80 to 49 days per year).

\title{
Introduction
}

\author{
"A lake is the landscape's most beautiful and \\ expressive feature. It is earth's eye; looking into \\ which the beholder measures the depth of his \\ own nature." Henry David Thoreau
}

Silver Lake is a 672-acre inland lake located along the eastern shore of Lake Michigan in Oceana County, Michigan. The lake is separated from Lake Michigan by a large dune complex of rolling sand hills that measures about 1.5 miles (mi) wide and about $3 \mathrm{mi}$ long (http://www.thinkdunes.com). These dunes are considered one of the largest deposits of living dunes on the shores of Lake Michigan, as the dunes continue to grow and move, covering cabins and filling in approximately 18 acres of Silver Lake from 1950 to 2012 (Groves and others, 2013). During May-September, almost 1 million people visit Silver Lake and the surrounding sand dunes for outdoor recreation, including the 450-acre offroad vehicle (ORV) area owned by the Silver Lake State Park (SLSP). The Silver Lake sand dunes are the only dunes east of the Mississippi River where people are allowed to drive ORVs (http://www.thinkdunes.com). The recreational opportunities and the water resources of Silver Lake are considered a highly valued asset to the surrounding community and tourists alike. 


\section{Why Study Lakes in Michigan?}

\author{
There are more than 11,000 inland \\ lakes in the State of Michigan. Lakes have \\ always been important natural resources \\ and are highly valued for their recreational, \\ aesthetic, and scenic qualities. In Michigan \\ alone, the lake recreational industry is \\ estimated to bring $\$ 15$ billion per year \\ to the State (Stynes, 2002).
}

In 1989, the Silver Lake Improvement Board (SLIB) initiated a program to control the growth of the exotic aquatic plant Eurasian milfoil (Myriophyllum spicatum) and nuisance algae blooms. In addition to plant control, water-quality monitoring was conducted to evaluate baseline water quality conditions in Silver Lake.

In 2011, Progressive AE published the "Silver Lake 2011 Water Quality Monitoring Report," which evaluated data collected from 1989 to 2011. In that report, there were several key conclusions made:

1. Total phosphorus concentrations were relatively low (less than 0.01 milligrams per liter $[\mathrm{mg} / \mathrm{L}]$ ) in the spring and increased considerably in the summer months (from 0.03 to $0.04 \mathrm{mg} / \mathrm{L}$ ); this pattern has been observed repeatedly since 1989 (Progressive AE, 2011).

2. Water transparency of Silver Lake was moderate (Secchi depth 8.5 feet $[\mathrm{ft}]$ ) in the spring and low (Secchi depth $2.8 \mathrm{ft}$ ) in the summer, likely as a result of algal growth in the lake.

3. During $2010-11$, there were elevated ( 9 and 6 micrograms per liter $[\mu \mathrm{g} / \mathrm{L}]$, respectively) chlorophyll $a$ concentrations in the summer related to persistent algal blooms on the lake.

The 2011 Progressive AE study stated that, based on historical and recent data, Silver Lake appeared to be undergoing more accelerated eutrophication and if the trend continued, that there would be more frequent and prolonged algal blooms, reduced transparency, and a decline in overall water quality.

The SLIB concluded that a detailed interpretive study was necessary to help identify nutrient sources that could be causing algal blooms in the lake. The U.S. Geological Survey (USGS), in cooperation with the SLIB, and in collaboration with the Annis Water Resources Institute (AWRI) of Grand Valley State University, designed a study to assess the hydrologic and nutrient inputs to Silver Lake, as well as to identify the events and conditions that affect the nutrient chemistry and production of algal blooms in the lake. The primary purpose of this study was to help identify nutrient sources that could be causing algal blooms and eutrophication in Silver Lake in an effort to inform management decisions that could prevent or reduce the occurrence of future algal blooms.

\section{Purpose and Scope}

This report describes the hydrology and water quality of Silver Lake with emphasis on nutrient loading. The objectives of this report are to (1) describe the Silver Lake watershed and historical water-quality monitoring studies; (2) describe current water quality in the lake, groundwater, tributaries, and atmosphere; (3) quantify the water and nutrient budgets for Silver Lake and estimate the contribution of septic systems; (4) identify the nutrient(s) limiting algal growth in Silver Lake; and (5) present model scenarios of future lake conditions in response to changes in nutrient loading inputs. The BATHTUB model developed by the U.S. Army Corps of Engineers (Walker, 1996) was used to simulate current conditions in the lake and nutrient loading scenarios.

\section{Silver Lake and Surrounding Watershed}

Located in Oceana County, Michigan, Silver Lake is a 672-acre natural inland lake with a volume of 9,823 acre-feet (acre-ft) and a maximum depth of $22 \mathrm{ft}$ (Groves and others, 2013) (fig. 1). Silver Lake is located about 8 miles (mi) west of Hart, Mich., and about $31 \mathrm{mi}$ south of Ludington, Mich. Silver Lake is situated along the eastern shore of Lake Michigan and is separated from the Great Lake by a large 2,000 -acre dune formation to its west and northwest. The Silver Lake shoreline is mostly developed on the east and north shores of the lake, with the remaining shoreline associated with the State of Michigan-owned Silver Lake State Park (SLSP). SLSP consists of a campground on the eastern shore of the lake, and almost 3,000 acres of dune and mature forest on the western and northern shores of the lake. Silver Lake is the last inland lake in a "chain-of-lakes," including Upper Silver Lake, Lake Holiday, and Wyckoff Lake that are connected by a series of tributaries. Silver Lake empties through Silver Creek and ultimately drains into Lake Michigan (fig. 2).

Hunter Creek is the main tributary to Silver Lake, which includes drainage from the Hunter Creek Basin as well as drainage from Upper Silver Lake (fig. 2). Two additional smaller tributaries that were monitored as part of this project included a small tributary near the SLSP campground and another small tributary located north of SLSP on North Shore Drive.

The soils near Silver Lake consist mainly of welldrained sandy deposits, including Grattan sand (rapid permeability), Epworth fine sand (rapid permeability), and Covert sand (moderate permeability) along with Pipestone fine sand (somewhat poor permeability) along the eastern perimeter of Silver Lake and dune land (rapid permeability) along the western side of the lake (U.S. Department of AgricultureNatural Resources Conservation Service, 2015). 


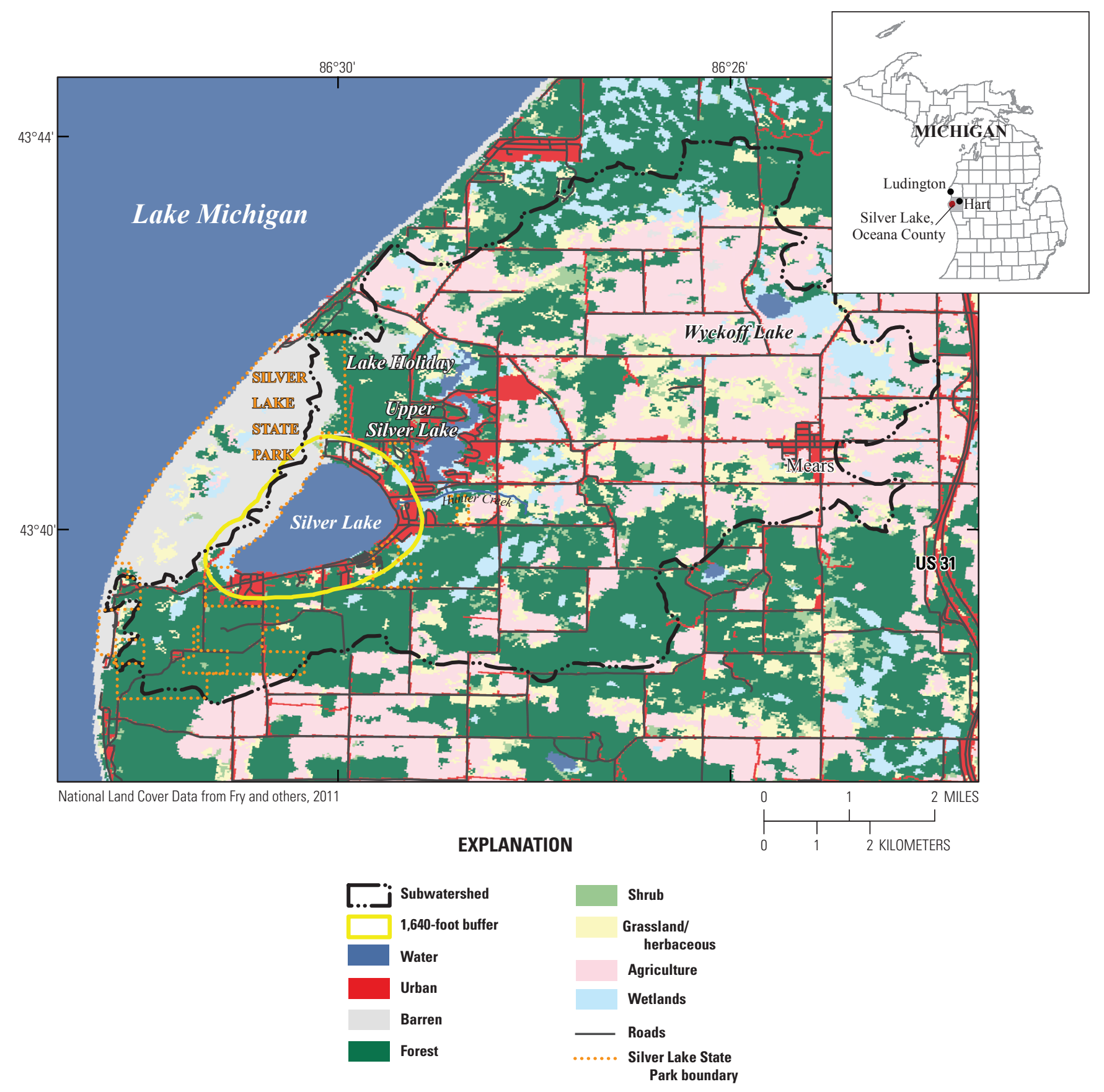

Figure 1. Silver Lake watershed delineation and land-use classifications, Oceana County, Michigan. 


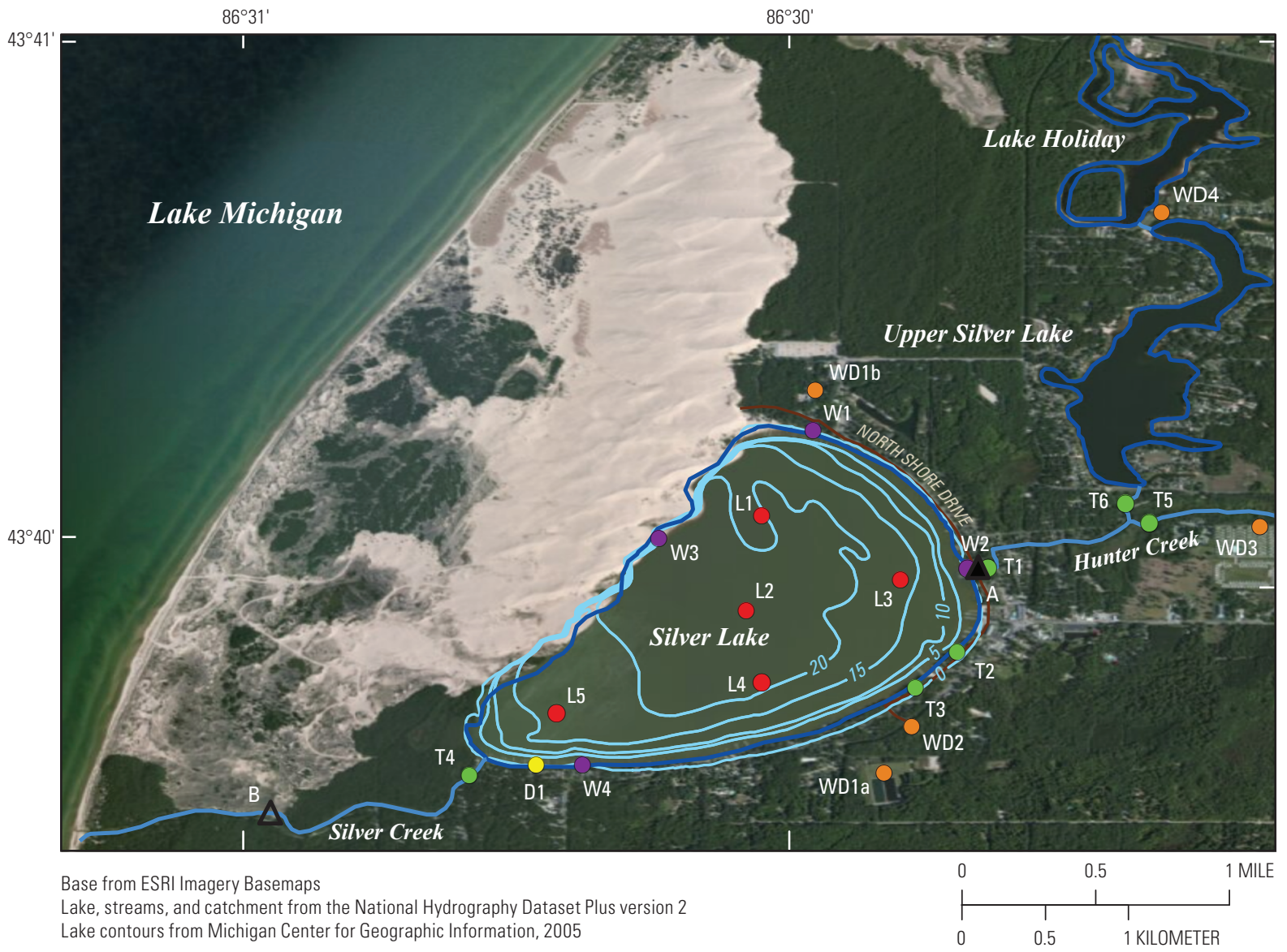

EXPLANATION

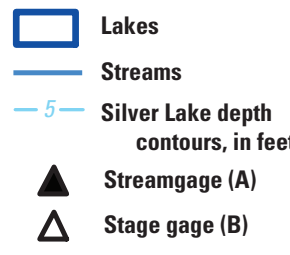

Atmospheric deposition station (D)

Lake (L)

Tributary (T)

Well (W)

Wastewater discharge (WD)

Figure 2. Silver Lake sampling locations, Oceana County, Michigan. 


\section{Land Use}

The Silver Lake watershed drains approximately 25 square miles $\left(\mathrm{mi}^{2}\right)$, and the area is predominantly forest (38 percent) and agriculture (26 percent). Developed and grassland/herbaceous land each account for 9 percent of the watershed, and the remaining land use consists of 6 percent wetlands, 5 percent water, and 3 percent barren and shrub according to the 2006 National Land Cover Database (Fry and others, 2011) (fig. 1). The land use within 1,640 ft of Silver Lake is predominantly barren (dune) (33 percent), developed (29 percent), and forest (23 percent). The remaining land use including wetlands, grassland/herbaceous, shrub, and agriculture make up the remaining 15 percent of land use within $1,640 \mathrm{ft}$ of the lake. However, approximately 65 percent of the shoreline around Silver Lake has been developed, while the remaining shoreline is primarily dune with a small percentage of wetland and forest land cover.

In the mid- to late $1800 \mathrm{~s}$, the lumber industry was booming in the small towns of Hart and Mears near Silver Lake. When the lumbering era came to an end in the early 1900s, residents found the land to be a great location for orchards. Currently, Oceana County boasts to having the largest number of peach and pear trees, by acreage, in the State of Michigan. It is the largest supplier of asparagus in the State and is known as the Asparagus Capital of the World (Pure Michigan, 2015). In addition, Oceana County also has the second largest amount of Christmas tree acreage in the State, dominated by Douglas Fir (Curtis and others, 2012).

\section{Population}

Silver Lake became a tourist destination in the early 1920 s and cottages quickly began to appear along the eastern edge of Silver Lake. As access became more readily available, more visitors began to flock to the area (Curtis and others, 2012). Malcolm "Mac" Wood is credited for creating the area's first "dune scooter" in 1927 (Curtis and others, 2012).

According to the 2010 U.S. Census, Golden Township had a population of 1,742 persons (U.S. Census Bureau, 2010). However, the population data from the 2010 Census is an estimate of the permanent year-round population and those that are seasonal or visitors are not included in these estimates. Since the population is primarily seasonal, the estimated number of persons may range from less than 1,000 during the winter months to over 14,000 in the peak summer months. With the inclusion of single day visitors, the population can increase to over 20,000 in the summer months and nearly 25,000 on the 4th of July. An estimated 772,231 people visited SLSP in 2014, and two-thirds of those were visitors to the ORV dune recreation area (DeJong, 2015).
Based on a review of the Oceana County parcel maps, there are approximately 192 homes and cottages located on Silver Lake and approximately 610 homes and cottages in the Silver Lake area that are not located on the lake itself. The Silver Lake area (properties within approximately $1 \mathrm{mi}$ of Silver Lake) is a seasonal community where the vast majority of the housing units are occupied during the summer.

There are 9 campgrounds located within $1.5 \mathrm{mi}$ of Silver Lake with a total of approximately 1,693 camp sites. The camping experience ranges from sites with no utilities to mobile and modular homes that typically remain in place. Campgrounds in the Silver Lake area are considered seasonal, and no campgrounds are open from November through March. In general, there are very few campers in April, May, September, and October while most usage of the sites occurs from the end of May through mid-September. In addition, there are 3 hotels in the Silver Lake area with approximately 156 hotel rooms. All of the local hotels typically operate from April through October and are closed throughout the winter (DeJong, 2015).

\section{Climate}

The mean high air temperatures at Silver Lake typically occur in July and August, with the lowest temperatures experienced during January and February. The mean annual precipitation in rainfall is 32-34 inches (in.), and lake-effect snowfalls average from 100 to 140 in. The months with the greatest amount of precipitation tend to be May, August, and September, and the driest month is February. A lake-modified climate results in a long growing season of 140 to 150 days which, coupled with late spring warming, makes the climate suitable for commercial fruit production (Curtis and others, 2012).

\section{Permitted Discharges}

Currently (2015), there are four approved wastewaterdischarge permits on file within the Silver Lake watershed and all are groundwater discharge permits. There are currently no surface-water discharge permits within the watershed. The Michigan Department of Environmental Quality (MDEQ) has issued the following discharge permits:

1. Silver Lake State Park (SLSP) / Michigan Department of Natural Resources (MDNR), effective February 1, 2010, expired February 1, 2015, new permit re-issued and in effect March 1, 2015 through March 1, 2018, Permit \#GW1810028 (fig. 2, sites WD1a and WD1b). The SLSP permit allows for discharge via spray irrigation on land surfaces (SLSP lagoon system and irrigation 
field) and subsurface disposal through septic tanks and tile fields (ORV public toilets, manager's residence, and SLSP office/garage) from April 15th through October 31 st. The discharge permit that was in effect from February 1, 2010 through February 1, 2015, authorized the SLSP to discharge 66,000 gallons per day (gal/d) $(2,700,000$ gallons per year [gal/yr]) of sanitary wastewater to the groundwater. The re-issued permit allows for maximum daily surface discharge of 132,000 gal/d (spray irrigation), and subsurface discharge not to exceed 264,000 gallons per week and 8,000 gal/d to the tile fields. The new permit allows for a maximum cumulative annual discharge (that is, surface and subsurface) of 4,806,915 $\mathrm{gal} / \mathrm{yr}$. This permit requires that discharge is recorded daily during discharge, and effluent waterquality testing is conducted weekly during discharge and analyzed for nutrients (total inorganic nitrogen, ammonia, nitrate, nitrite, and total phosphorus), $\mathrm{pH}$, chloride, sodium, total suspended solids (TSS), and biochemical oxygen demand (BOD). Soil samples are collected annually (every August) from the land application site and monitored for total phosphorus, sodium, $\mathrm{pH}$, and cation exchange capacity. Groundwater quality and groundwater elevations also are monitored upgradient and downgradient of the treatment lagoons on a quarterly basis (February, May, August, and November) and analyzed for nutrients, metals, chloride, and sodium. They are analyzed annually for calcium, magnesium, potassium, bicarbonate, and sulfate.
2. Sandy Shores Campground, effective August 1, 2014, expires August 1, 2016, Permit \#GW1110131 (fig. 2, site WD2). This permit allows for discharge to groundwater via subsurface disposal through a septic tank and tile field. This permit authorizes discharge of less than $10,000 \mathrm{gal} / \mathrm{d}$ and requires weekly flow measurement reporting; however, no water-quality monitoring is required under this permit.

3. Silver Creek RV Resort LLC, effective April 1, 2011, expires April 1, 2016, Permit \#GW1110253 (fig. 2, site WD3). The discharge permit requirements for Silver Creek RV Resort are the same as for Sandy Shores Campground permit; subsurface disposal to groundwater through a septic tank and tile field and authorized to discharge less than 10,000 gal/d with weekly flow monitoring and no water-quality requirements.

4. Grace Adventures Campground, effective January 1, 2015, expires January 1, 2018, Permit \#GW1110724 (fig. 2, site WD4). This campground is not yet operational; however, the permit for groundwater discharge less than $10,000 \mathrm{gal} / \mathrm{d}$ with weekly flow monitoring will be required. 


\section{History of Monitoring on Silver Lake}

There is a long history of water-quality monitoring on Silver Lake. The results of these studies were used in the development of the current study objectives and to support the findings discussed in this report. A brief summary of the monitoring studies are discussed in the following sections and summarized in table 1.

Table 1. Historical and current water-quality studies for Silver Lake, Oceana County, Michigan, and associated analytes.

[MSU, Michigan State University; WQI, Water Quality Investigators; USGS, U.S. Geological Survey; MDEQ, Michigan Department of Environmental Quality]

\begin{tabular}{|c|c|c|c|c|c|c|c|c|c|}
\hline Study & $\begin{array}{c}\text { Water } \\
\text { transparency } \\
\text { (Secchi depth) }\end{array}$ & $\begin{array}{l}\text { Surface- } \\
\text { water } \\
\text { nutrients }\end{array}$ & Chlorophyll a & $\begin{array}{l}\text { Bacterio- } \\
\text { logical } \\
\text { data }\end{array}$ & $\begin{array}{c}\text { Physical } \\
\text { water-quality } \\
\text { data }\end{array}$ & $\begin{array}{l}\text { Ground- } \\
\text { water }\end{array}$ & $\begin{array}{l}\text { Atmospheric } \\
\text { deposition }\end{array}$ & $\begin{array}{l}\text { Internal } \\
\text { nutrient } \\
\text { loading }\end{array}$ & $\begin{array}{c}\text { Microcystin } \\
\text { and } \\
\text { phytoplankton }\end{array}$ \\
\hline $\begin{array}{l}2011 \text { Water Quality } \\
\text { Monitoring Report, } \\
\text { Progressive AE }\end{array}$ & $\mathrm{X}$ & $\mathrm{X}$ & $\mathrm{X}$ & $\mathrm{X}$ & $\mathrm{X}$ & & & & \\
\hline $\begin{array}{l}\text { A Pilot Study: Silver Lake } \\
\text { Water Quality-MSU }\end{array}$ & & & & $\mathrm{X}$ & $\mathrm{X}$ & & & & \\
\hline $\begin{array}{l}\text { Study of Silver Lake } \\
\text { Water Quality-MSU }\end{array}$ & & & & $\mathrm{X}$ & $\mathrm{X}$ & & & & \\
\hline $\begin{array}{l}\text { A Water Quality \& Wa- } \\
\text { tershed Management } \\
\text { Study-WQI }\end{array}$ & $\mathrm{X}$ & $\mathrm{X}$ & $\mathrm{X}$ & $\mathrm{X}$ & $\mathrm{X}$ & & & & \\
\hline $\begin{array}{l}\text { Friends of Silver Lake } \\
\text { Monitoring }\end{array}$ & & $\mathrm{X}$ & & & & & & & \\
\hline $\begin{array}{l}\text { Michigan Cooperative } \\
\text { Lakes Monitoring } \\
\text { Program }\end{array}$ & $\mathrm{X}$ & $\mathrm{X}$ & $\mathrm{X}$ & & $\mathrm{X}$ & & & & \\
\hline $\begin{array}{l}\text { Michigan Inland Lakes } \\
\text { Report-USGS/MDEQ }\end{array}$ & $\mathrm{X}$ & $\mathrm{X}$ & $\mathrm{X}$ & & $\mathrm{X}$ & & & & \\
\hline $\begin{array}{l}\text { Silver Lake Nutrient } \\
\text { Study, 2012-14 } \\
\text { (this report) }\end{array}$ & $\mathrm{X}$ & $\mathrm{X}$ & $\mathrm{X}$ & $\mathrm{X}$ & $\mathrm{X}$ & $\mathrm{X}$ & $\mathrm{X}$ & $\mathrm{X}$ & $\mathrm{X}$ \\
\hline
\end{tabular}

\section{Silver Lake-2011 Water Quality Monitoring Report, Progressive AE}

The 2011 Water Quality Monitoring Report summarized the key water-quality data that had been collected periodically since 1989 in an effort to evaluate baseline water-quality conditions in the lake. Monitoring results indicated that Silver Lake is isothermic and well-oxygenated throughout the water column; phosphorus levels have been increasing; water clarity has decreased; and while chlorophyll $a$ levels have been decreasing slightly, high chlorophyll $a$ concentrations in the summers of 2010 and 2011 ( 9 and $6 \mu \mathrm{g} / \mathrm{L}$, respectively) coincided with significant algal blooms. Fecal coliform bacteria samples were collected from near-shore areas around the lake; sample results were low, indicating a minimal health threat. The study concluded that Silver Lake can currently be classified as a meso-eutrophic lake and that the lake is currently undergoing accelerated eutrophication (Progressive AE, 2011).

\section{A Pilot Study: Silver Lake Water Quality- Michigan State University}

In 2006, a study was conducted to evaluate the level of fecal pollution in Silver Lake, potentially associated with septic tanks in the area. Multiple microbial indicators were monitored as part of this pilot study, including Escherichia coli (E. coli), enterococci, and Clostridium perfringens ( $C$. perfringens). In addition, coliphage, a type of virus that infects $E$. coli bacteria, was analyzed to determine if fecal contamination was caused from recent or past events. This study was conducted on August 30,2006 , at 11 sites around the perimeter of the lake, including one site located on Lake Michigan near the mouth of Silver Creek. Results indicated that water quality at numerous sites was considered impaired based on the MDEQ recreational freshwater standards for total-body and partial-body contact for $E$. coli for a single day (less than or equal to 300 colony-forming units per 100 milliliters [CFU/100 mL)], less than or equal to 1,000 CFU/100 mL, respectively) and the U.S. Environmental 


\section{Why are Nutrients Important?}

Nutrients are essential for natural plant and animal growth; however, excessive concentrations of nutrients can adversely affect aquatic life and human health. Elevated nutrient concentrations in streams and lakes can trigger eutrophication, which results in excessive, often unsightly, growth of algae and aquatic plants. As the plants and algae decay, there are often foul odors produced as well as low dissolved oxygen in water (hypoxia), which can harm fish and shellfish. High nutrient concentrations also can cause growth of harmful algae, which can be potentially toxic to fish and other organisms, including humans (U.S. Geological Survey, 2014).

Protection Agency (EPA) criterion for total-body contact for enterococci (less than or equal to $33 \mathrm{CFU} / 100 \mathrm{~mL}$ [single day], less than or equal to $151 \mathrm{CFU} / 100 \mathrm{~mL}$ (infrequently used]). Six of the 11 sites exceeded the MDEQ standards for E. coli (from 2,367 CFU/100 mL to too numerous to count [TNTC]), and 2 of the 11 sites exceeded the EPA standards for enterococci (from 177 to $443 \mathrm{CFU} / 100 \mathrm{~mL}$ ). The study concluded that Hunter Creek and a small ephemeral tributary near Floradale Resort (not monitored as part of this study due to minimal streamflow as well as the ephemeral nature of the tributary) were contributing to higher microbial concentrations, and that there also were higher concentrations found near the shoreline indicating that septic tanks also may be contributing to higher bacterial concentrations. Also, five sites had detectable coliphage, which was indicative of recent and widespread fecal pollution (Rose and Shibata, 2006).

A follow-up study was conducted by Michigan State University (MSU) in 2007. Study results indicated that recreational water quality was not impaired at Silver Lake during that period. However, Hunter Creek was still considered a significant source of pollution to the lake. Recommendations included adding more sampling events throughout the swimming season to further evaluate the risk associated with recreating in Silver Lake (Verhougstraete and others, 2007).

\section{Silver Lake Water Quality and Watershed Management Study, 2001—Water Quality Investigators}

In 2000, Water Quality Investigators conducted a study to evaluate the water quality of Silver Lake and the watershed. Water samples were collected on two occasions in Silver Lake, April 26, 2000, and August 25, 2000, and analyzed for nutrients and chlorophyll $a$. In addition, Hunter Creek was sampled on nine occasions from October 24, 1999 through November 1,2000 . The results from this small study indicated that water transparency decreased from spring to summer and that surface to bottom phosphorus concentrations were essentially the same, demonstrating that the lake was well mixed (Fusilier and Fusilier, 2001). The study indicated that Silver Lake and Hunter Creek are receiving nutrients from on-site septic systems and that plant abundance and algae production will continue to increase if nothing is done to reduce the nutrient inputs (Fusilier and Fusilier, 2001).

\section{Friends of Silver Lake Monitoring}

Since 2011, the Friends of Silver Lake have funded the nutrient analysis of samples collected by volunteers from Silver Lake, its tributaries, and other contributing waterbodies (www.friendsofsilverlake.org/reports-maps/).

\section{Michigan Cooperative Lakes Monitoring Program}

The Cooperative Lakes Monitoring Program (CLMP) has existed in Michigan for over 40 years with the purpose of helping citizen volunteers monitor indicators in water quality and document changes over time. From May 2012 through April 2013, a CLMP volunteer collected water-quality data on Silver Lake. These data include Secchi-disk depth, total phosphorus, chlorophyll $a$, and dissolved oxygen and temperature profiles (www.micorps.net/data). This information is used to provide baseline lake data for the State, to educate lake residents and citizens, and to build support for lake quality protection.

\section{Water Quality Characteristics of Michigan's Inland Lakes, 2001-10_USGS/MDE0}

USGS and MDEQ conducted a joint study during 2001-10 in which 729 lakes greater than 25 acres (with public boat-launch access) were monitored as part of Michigan's Lake Water-Quality Assessment program. Silver Lake was included in the study and was monitored in 2005 for nutrients, Secchi depth (transparency), chlorophyll $a$, major ions, and other physical properties including vertical-profile measurements. Based on 2005 data, the lake was classified as eutrophic. This study compared water-quality data results and lake trophic status with historical data collected during 1974-84 by the MDEQ (Fuller and Taricska, 2011). 


\section{Study Methods and Sampling Sites}

USGS and AWRI scientists collected data from November 2012 to December 2014 to inform future management decisions for Silver Lake. Volunteers also aided in the data collection effort for collection of atmospheric nutrient deposition data. Site information and water-quality data collected from previous studies aided in the overall study design for this project; however, the data used in the analyses for this study were collected from November 2012 to December 2014. The following sections detail the site selection criteria and methods used in this study.

\section{Silver Lake Study Overview}

This report includes several sections describing the study design and results. Figure 3 summarizes the numerous components of the project and some of the key questions related to the study.

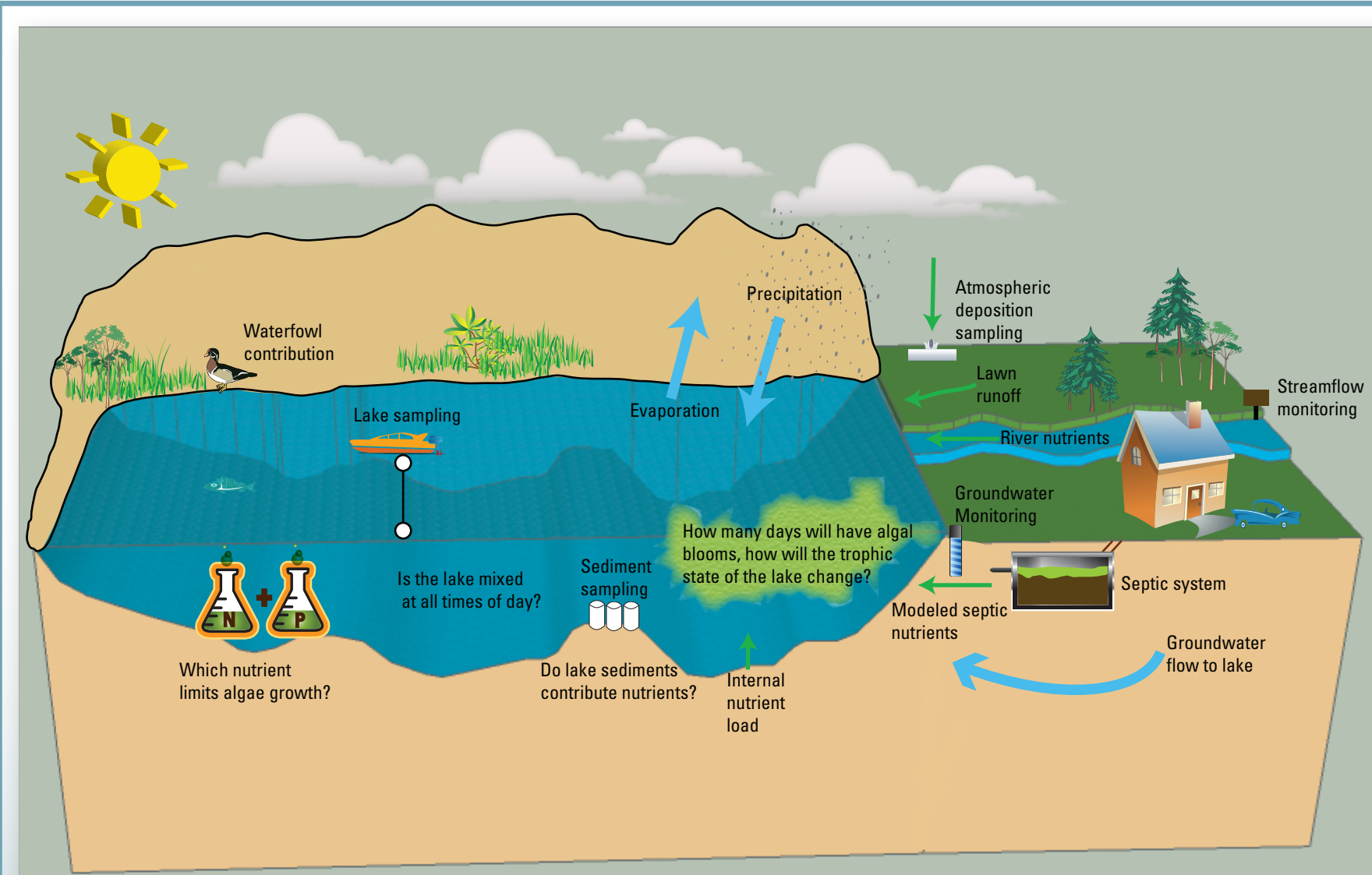

Lake Status.

Modeled Septic Input. $52-54$

Water Budget $37-38$

Nutrient Budget. $38-47$

Lake Mixing.

$34-35$

Limiting Nutrients.

34,37

Sediment Sampling and Internal Nutrient Load....42-45

Algal Bloom Frequency and Lake Trophic State....50-52

Nutrient Sampling $39-40$

Figure 3. Overview of study in Silver Lake Oceana County, Michigan. 


\section{Site Selection}

Silver Lake was divided into five sections (north, middle, east, southeast, and south) and monitoring locations were established in each section. The middle section includes the historic deep basin location sampled in previous studies (L2; fig. 2). After the first year of lake monitoring (2013), the lake water-quality data were evaluated to determine if there was spatial variation between lake measurement locations. Using the Wilcoxon signed-rank test (Helsel and Hirsch, 2002), results indicated that there was no significant difference ( $p$-value $>0.05$ ) in the water-quality data collected from the five lake sampling locations for that year. As a result, the three lake sites that showed the most variation were kept in the sampling design (north (L1), middle (L2), and south (L5) sites), which were sampled through 2014 (fig. 2). Sampling location information is presented in table 2 .

All major inflows and outflow were monitored as part of this study. These included Hunter Creek (T1), the unnamed tributary to Silver Lake at North Shore Drive (tributary at North Shore Drive) (T2), the unnamed tributary to Silver Lake at the North End State Park (tributary at the State Park) (T3), and Silver Creek (outlet) (T4) (fig. 2, table 2). Some of the smaller ephemeral tributaries and drains were not directly measured as part of this study due to the minimal flow contributions to the lake. A continuous streamgage was installed at Hunter Creek (A) to measure streamflow into the lake, and (B) to continuously monitor the stream stage at Silver Creek dam to use in the estimation of streamflow leaving the lake (fig. 2, table 2).

Groundwater-monitoring locations were determined based on reconnaissance synoptic groundwater sampling that was conducted in October 2012 using a temporary drive-point piezometer (DPP) at 17 locations in the nearshore/beach environment around the perimeter of the lake (see Groundwater Monitoring and Flow section of this report). As a result of the groundwater reconnaissance, four locations [north (W1), south (W4), east (W2), and west (W3)] were identified for installation of monitoring wells for longer term groundwater-level measurements and groundwater sampling (fig. 2, table 2). The piezometer installation locations also were chosen to represent expected variable inputs from septic systems around the lake. Direct groundwater discharge to the lake was measured using seepage meters (Rosenberry and LaBaugh, 2008) that were temporarily installed at 18 locations around the perimeter of the lake. Lastly, an array of discrete temperature sensors (Briggs and others, 2013) was deployed at five locations around the lake to estimate groundwater discharge rates to the lake.

Sediment cores were collected for internal nutrient loading analysis from the middle (L2) and south (L5) lake sites (fig. 2) on four separate dates in 2013 and 2014. Diel dissolved oxygen measurements were made at the near-surface and near-bottom of the lake at the middle and south lake sites on four separate dates in 2013. Water for an algal bioassay was collected at the middle lake monitoring site (L2) and then transported to the shore near the north groundwater monitoring well (W1) (fig. 2) to determine if nitrogen or phosphorus were limiting phytoplankton growth in Silver Lake.

The atmospheric deposition monitoring station was installed in December 2013 near the south end of Silver Lake (D1) (fig. 2). The location for the deposition station was carefully selected based on the proximity to Silver Lake, the absence of overhead and nearby vegetation, and easy accessibility for the volunteer conducting the sampling.

\section{Water-Quality Data; Collection}

A detailed summary of the water-quality data collection effort is presented in table 2. Data collected by the USGS as part of this study are publicly available and can be accessed via the USGS National Water Information System (NWIS) database (waterdata.usgs.gov/nwis) through use of the station number (table 2) to identify the sampling locations. All samples were collected according to the methods described in the USGS National Field Manual (U.S. Geological Survey, 2006) unless otherwise described. The constituents measured by USGS and AWRI in this study are presented in table 3. 


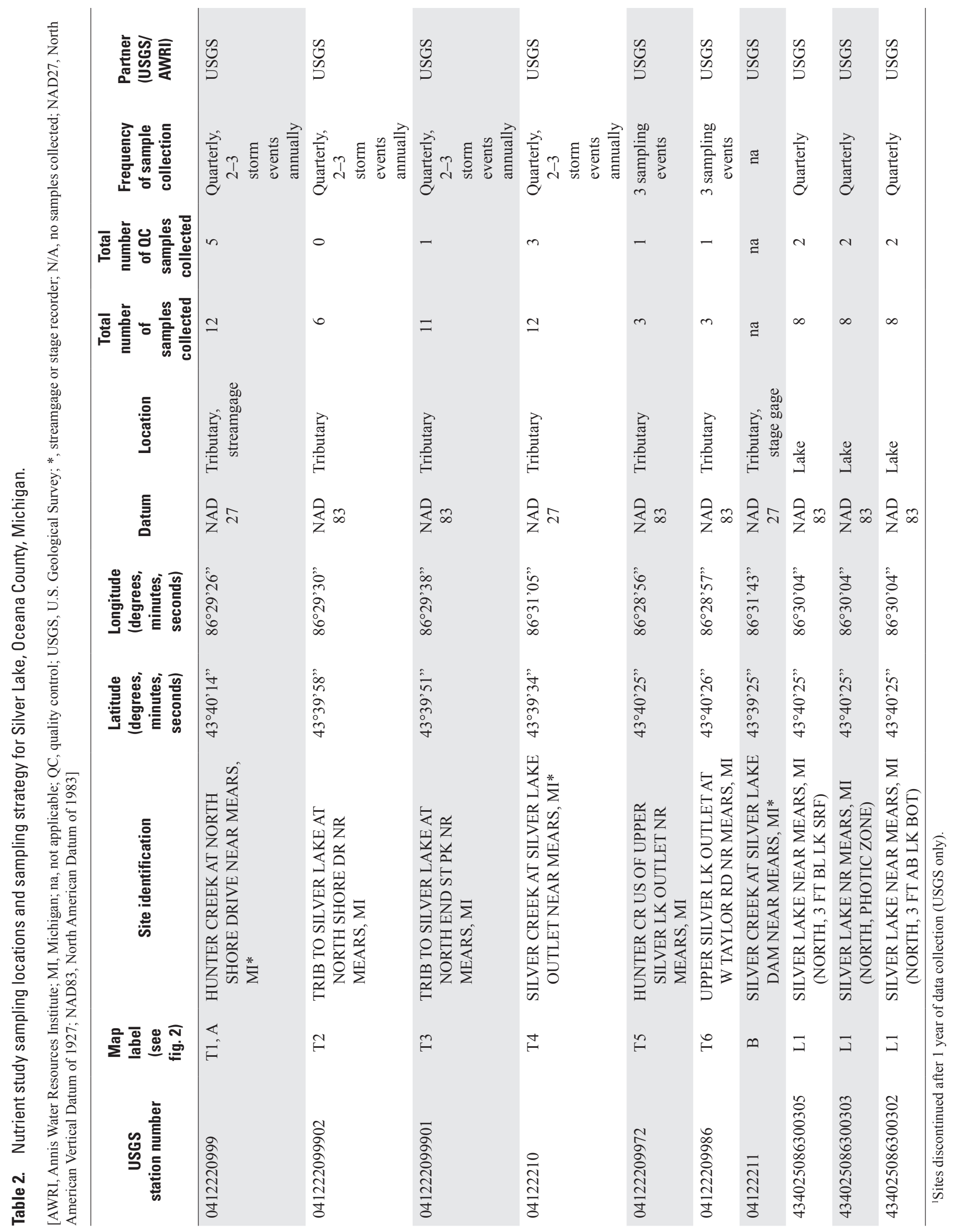




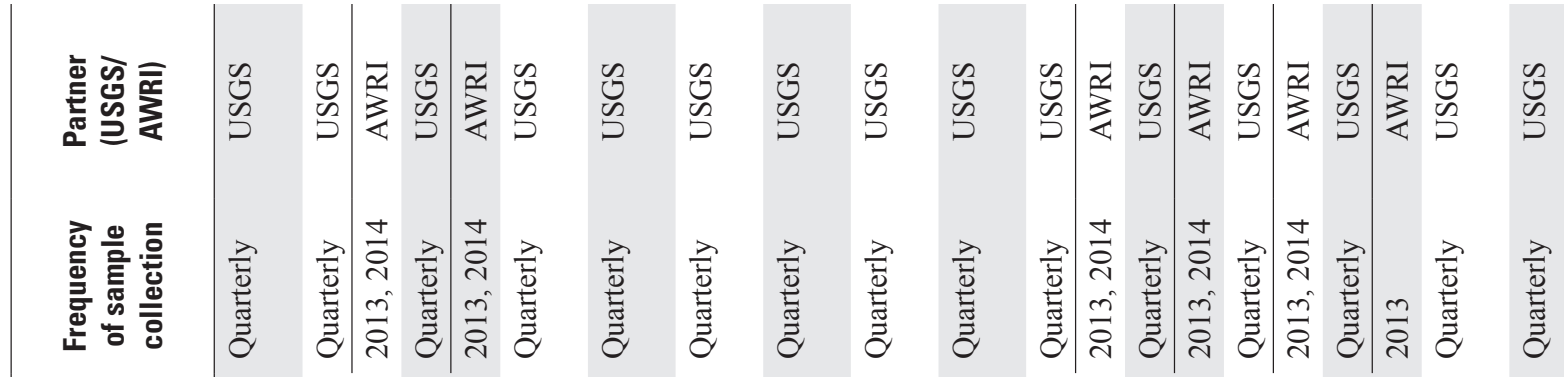

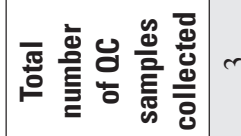

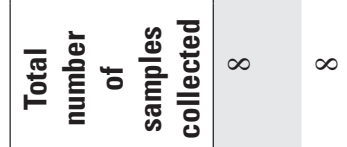

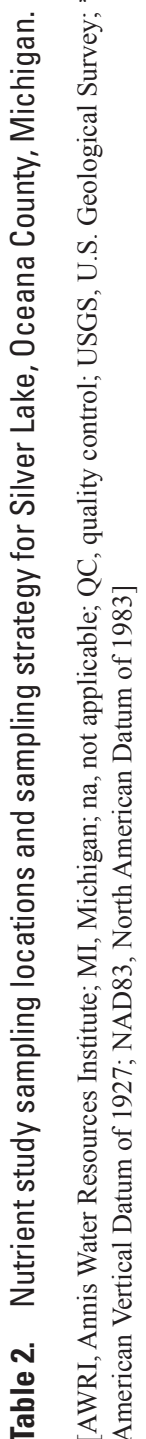

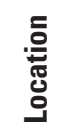

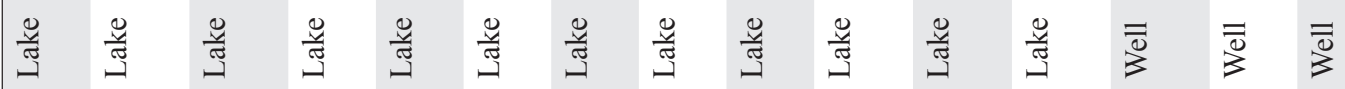

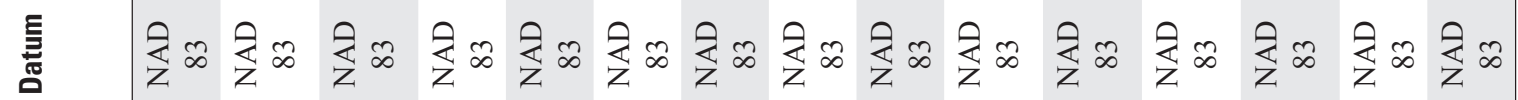

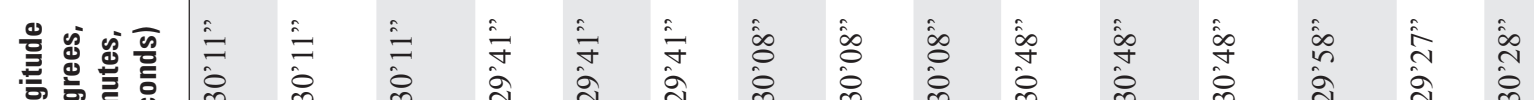

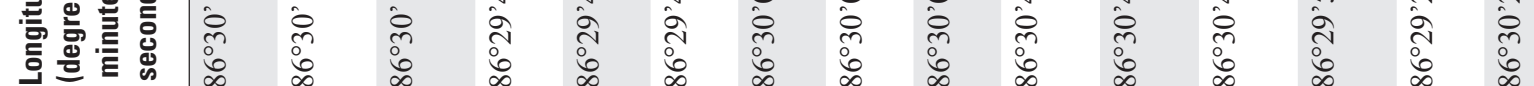

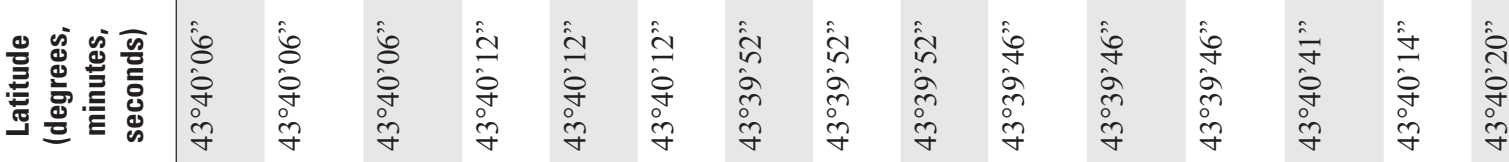

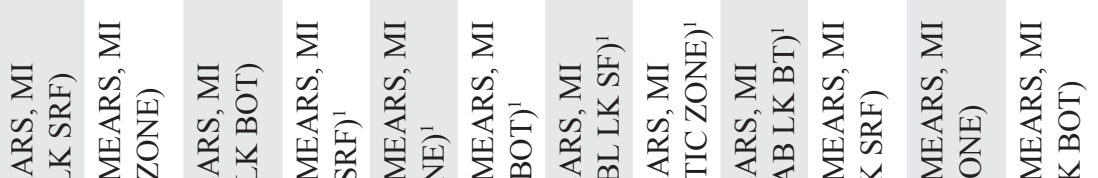

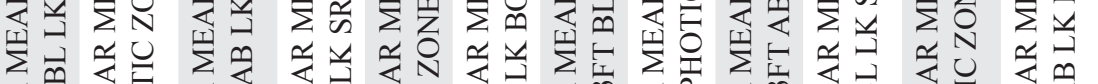

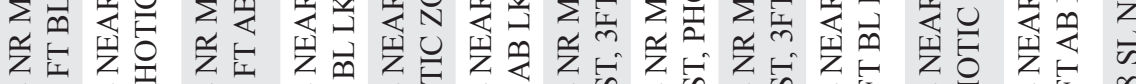

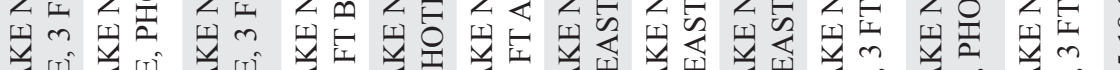

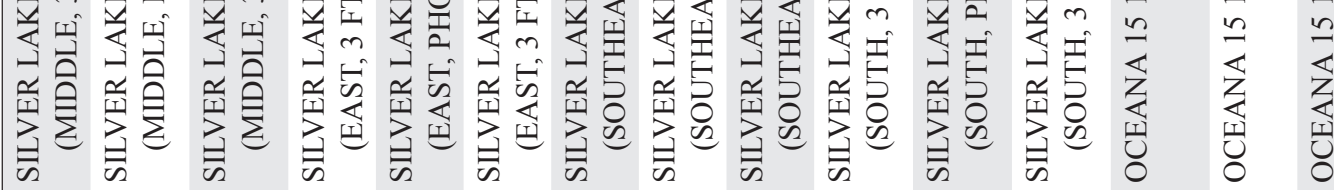

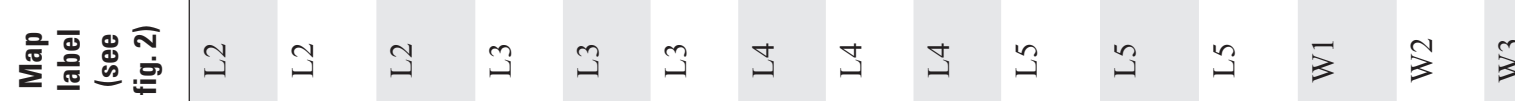

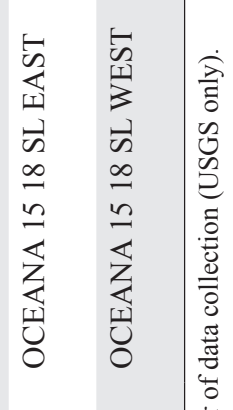
岁言

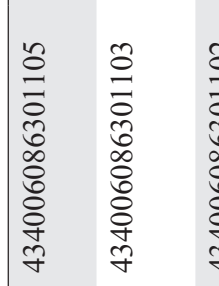
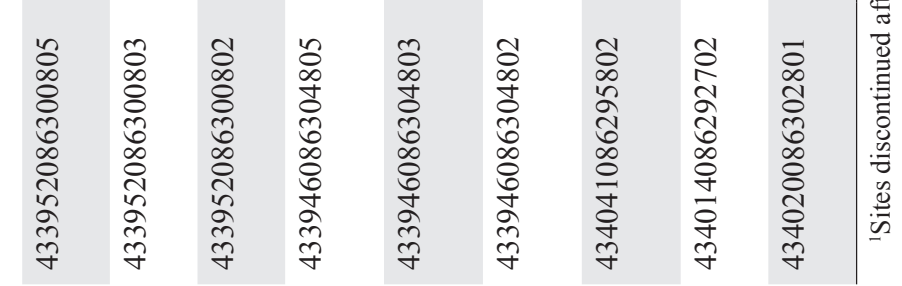


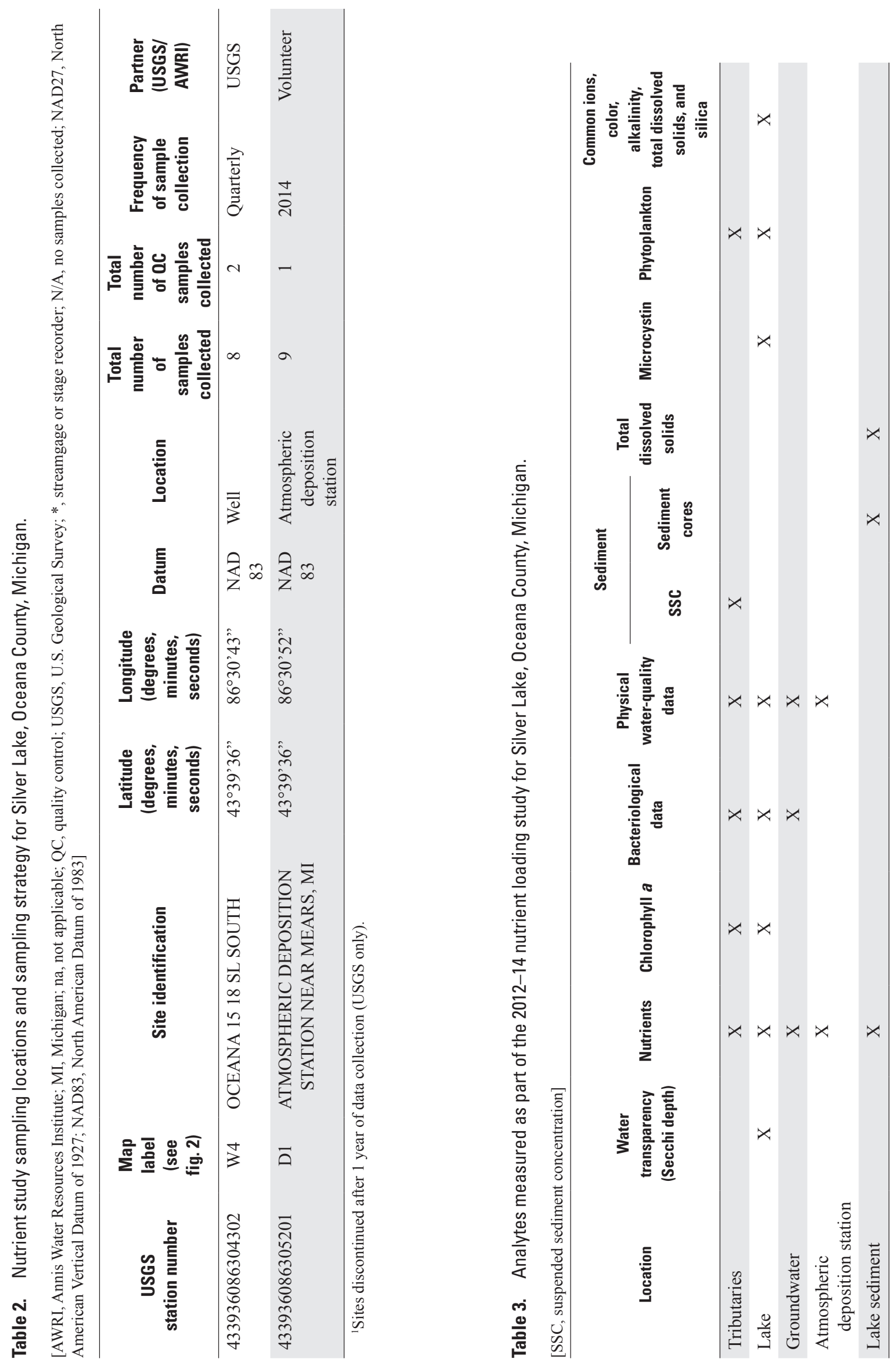




\section{A Summary of Nutrients}

Nutrients can come from natural sources such as eroding soils, decomposing plant material, and wildlife wastes; however, excess nutrients enter surface waters from pointsource discharges (a discrete pipe) as well as nonpoint sources (overland runoff).

\section{"In Michigan, nutrient control has focused on} phosphorus since the majority of surface waters are limited in this nutrient. Nitrogen reductions have been necessary when this nutrient was considered the limiting factor for plant productivity or has been the direct cause of water quality impairment" (Michigan Department of Environmental Quality, 2013).

\section{Phosphorus}

Phosphorus plays a major role in biological metabolism, and is an essential nutrient used by all organisms for the basic processes of life. Its natural source is the weathering and leaching of phosphate-rich geological formations. However, phosphorus is used extensively in agricultural and residential fertilizers, and is a component of domestic sewage (wastewater discharge, failing septic systems). Phosphorus also can enter the system through wet and dry atmospheric deposition, waterfowl feces, and plant decomposition. Phosphorus is considered a limiting nutrient in most Midwestern lakes, as phosphorus typically "limits" macrophyte and algal growth because it is less available for uptake than other nutrients, such as nitrogen (Wetzel, 1983). Aquatic plants may struggle to grow in lakes with little to no phosphorus, but may grow rapidly in systems with excessive amounts of phosphorus.

Nutrient loading in lakes can come from outside the lake (for example, atmospheric, tributaries, waterfowl), which is referred to as external loading, or from the sediments within the lake, which is referred to as internal loading. In the case of phosphorus, internal loading is often a function of sediment redox state, as anoxic conditions will cause the reduction of ferric iron $\left(\mathrm{Fe}^{3+}\right)$ to ferrous iron $\left(\mathrm{Fe}^{2+}\right)$, liberating phosphorus that is bound to ferric oxyhydroxides, resulting in phosphorus flux from the sediment to the overlying water column (fig. 4).

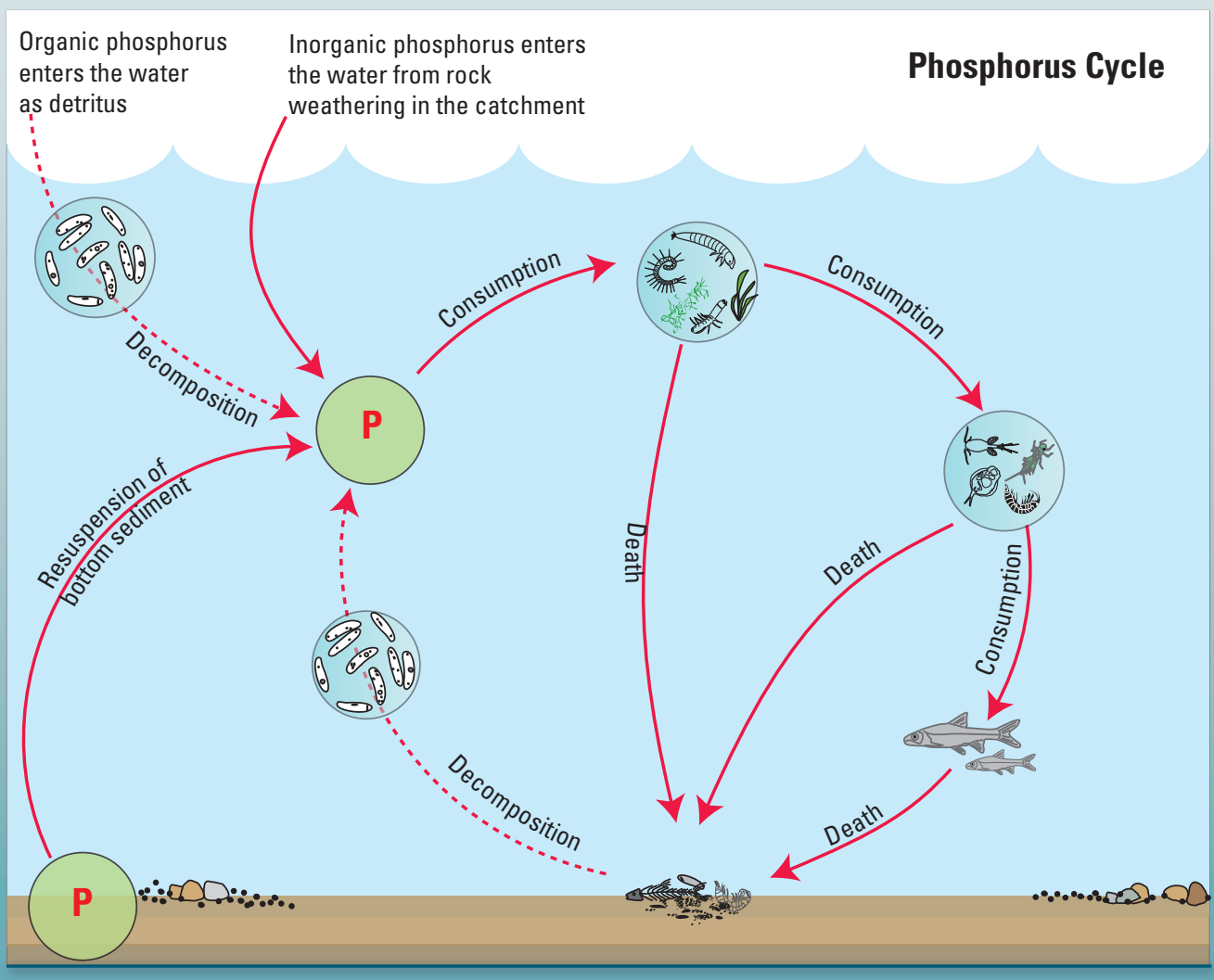

EXPLANATION

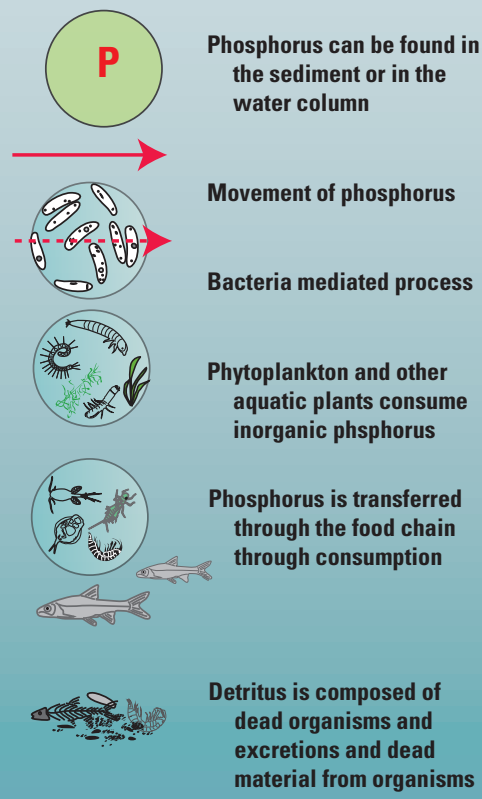

Figure 4. Phosphorus cycle in lakes. (Used with permission of the Queensland Government, Department of Environment and Heritage Protection.) 


\section{Nitrogen}

All organisms require the nutrient nitrogen to live and grow; it is a building block of cellular proteins. Many of the same sources that contribute phosphorus to the system also contribute nitrogen, and nitrogen is a major nutrient that affects the productivity of fresh waters. The nitrogen cycle is a complex biochemical process in which nitrogen in various forms is altered by nitrogen fixation, assimilation, and denitrification (Wetzel, 1983) (fig. 5).

\section{"Although nitrogen is abundant naturally} in the environment, it is also introduced through sewage and fertilizers. Some nitrate enters water from the atmosphere, which carries nitrogencontaining compounds derived from automobiles and other sources. Ammonia and organic nitrogen can enter water through sewage effluent and runoff from land where manure has been applied or stored" (U.S. Geological Survey, 2015b).

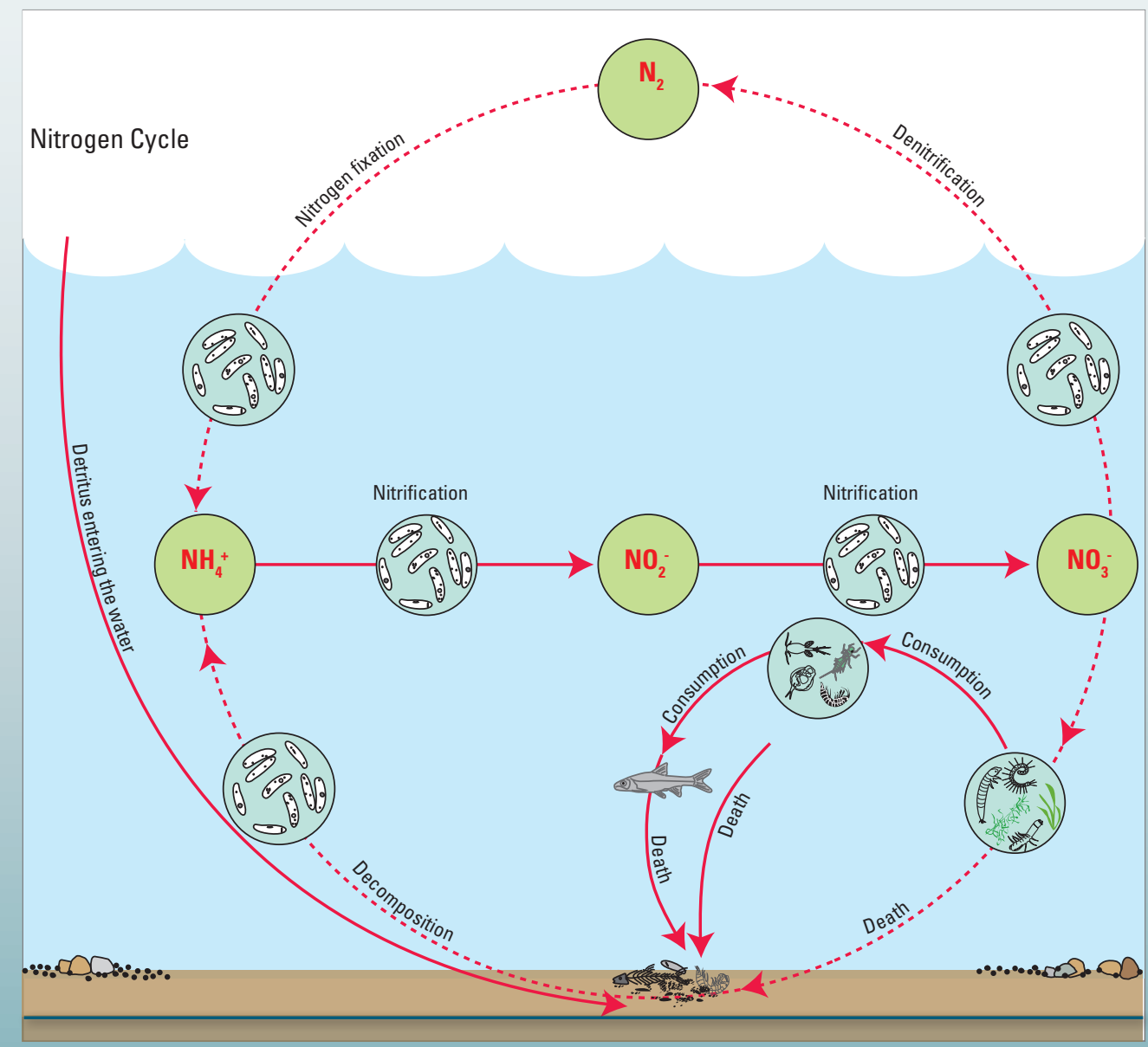

\section{EXPLANATION}
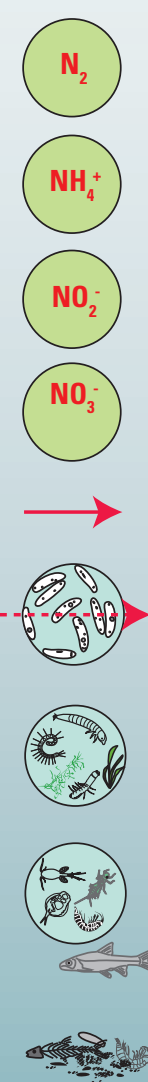

Nitrogen gas in the atmosphere

Ammonium

Nitrite

Nitrate

Movement of nitrogen

Bacteria mediated process

Phytoplankton and other aquatic plants consume nitrogen fixed by bacteria

Nitrogen is transferred through the food chain through consumption

Detritus is composed of dead organisms and excretions and dead material from organisms

Figure 5. Nitrogen cycle in lakes. (Used with permission of the Queensland Government, Department of Environment and Heritage Protection.) 


\section{Lake Monitoring}

Silver Lake monitoring was conducted on a quarterly basis by USGS personnel for a total of eight routine visits during November 2012-September 2014. During each visit, physical properties such as water temperature, dissolved oxygen, specific conductance, and $\mathrm{pH}$ were recorded using a YSI ProPlus multiparameter water-quality sonde. Turbidity was measured using a portable Hach Series 2100P Turbidimeter. A Secchi disk was used to record Secchi depth (water clarity) at all locations and to determine the photic zone required for the collection of chlorophyll $a$, phytoplankton, and E. coli samples.

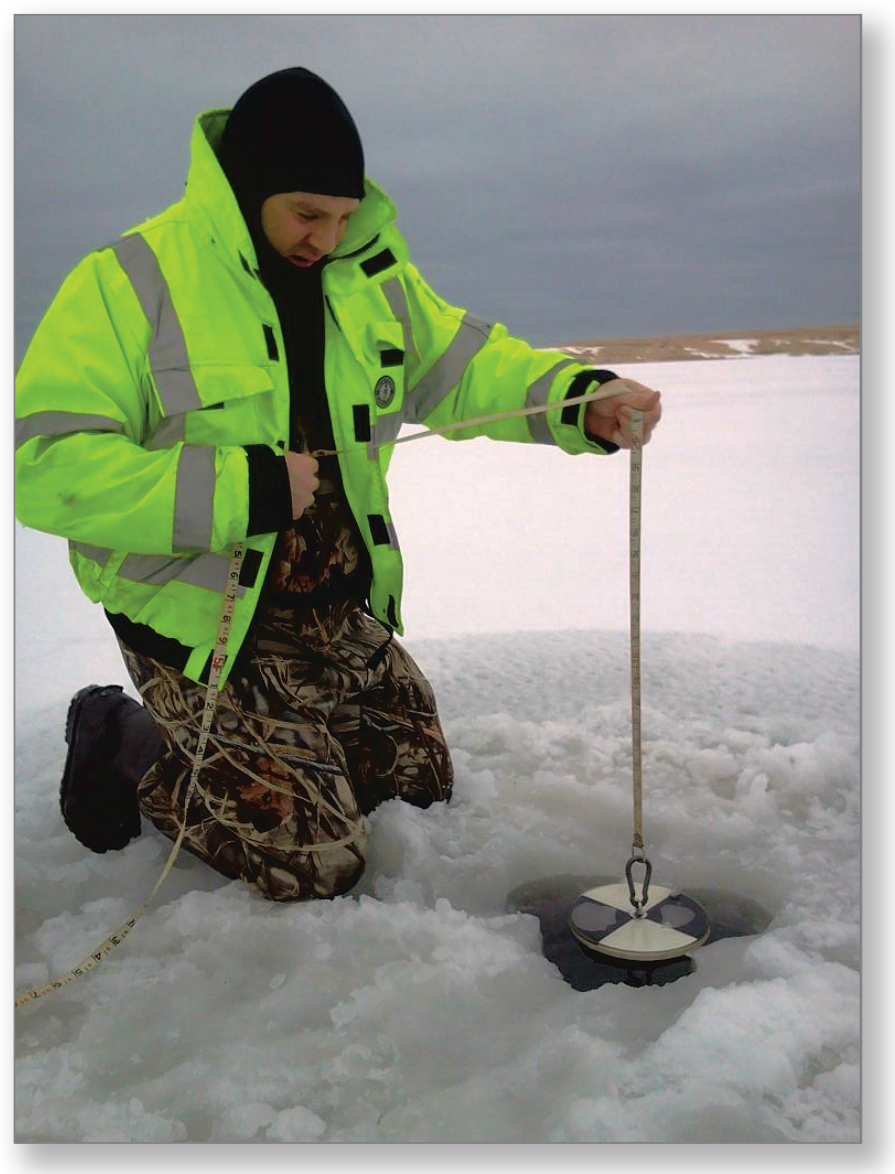

During the winter, the ice was augered in a clover-leaf fashion to allow the Secchi-disk to pass through the ice.

Water samples were collected near surface ( $3 \mathrm{ft}$ below the lake surface) and near bottom ( $3 \mathrm{ft}$ above lake bottom) in order to describe the distribution of constituents in the water column. Both the near-surface and near-bottom samples were analyzed for nitrogen (total nitrogen, ammonia, organic nitrogen, nitrite, and nitrate) and phosphorus (total phosphorus and orthophosphate). Chlorophyll $a$, phytoplankton, and $E$. coli samples were collected in the photic zone (twice the Secchi depth) of the water column (U.S. Geological Survey, 2006). Additional water samples were collected each spring
(2013 and 2014) at the middle lake site (L2; deepest basin) and analyzed for common ions, color, turbidity, alkalinity, total dissolved solids (TDS), and silica.

Near-surface and near-bottom lake samples were collected by lowering weighted $3 / 16$ in. peristaltic tubing to the appropriate depth in the water column. Lake water was then pumped through the tubing using a peristaltic pump. After field rinsing, water samples were collected from the end of the tubing, and filters $(0.45$ micron $[\mu \mathrm{m}])$ necessary for dissolved nutrient analysis were connected directly to the tubing. Clean tubing was used at each lake sampling location. The chlorophyll $a$, phytoplankton, and $E$. coli samples were collected using a weighted-bottle sampler that was manually lowered through the photic zone at a steady rate so as not to overfill the sample bottle.

\section{Internal Nutrient Loading}

Estimates of internal nitrogen and phosphorus loading from the sediments were made by incubating sediment cores in a climate-controlled growth chamber housed at the AWRI laboratory. Sediment cores were collected from the middle (L2) and south (L5) lake monitoring sites (fig. 2) on four separate dates over the project period: May 29, 2013; August 20, 2013; June 19, 2014; and August 20, 2014. Sediment core sampling and laboratory incubation followed the procedures of Steinman and others (2004). Six sediment cores were collected from each site using a piston corer (Fisher and others, 1992; Steinman and others, 2004). The corer was constructed of a graduated $0.6-$ meter $(\mathrm{m})$ long polycarbonate core tube (7-centimeter $[\mathrm{cm}]$ inner diameter) and a polyvinyl chloride (PVC) attachment assembly for coupling to aluminum drive rods. The piston was retracted 20 to $25 \mathrm{~cm}$ prior to deployment to maintain a water layer on top of the core during collection. The corer was positioned vertically at the sediment-water interface and pushed downward with the piston cable remaining stationary. After collection, the core was brought to the surface and the bottom was sealed with a rubber stopper prior to removal from the water, resulting in an intact sediment core that was approximately $20 \mathrm{~cm}$ in length, with a $25-\mathrm{cm}$ overlying water column. The piston was then bolted to the top of the core tube to keep it stationary during transit. Core tubes were placed in a vertical rack and maintained at ambient near-bottom water temperature during transit. An additional sediment core was collected from each site and the top $5 \mathrm{~cm}$ was removed for analysis of sediment total phosphorus and sediment elements (August 20, 2014 only) in the laboratory.

Water quality was measured at both coring locations at the time of core collection. Dissolved oxygen, $\mathrm{pH}$, temperature, specific conductance, turbidity, chlorophyll $a$, and TDS were measured at the surface, middle, and bottom of the water column using a YSI 6600 multiparameter water-quality sonde. Photosynthetically-active radiation (PAR) profiles were measured using a LiCor Li-193SA spherical quantum sensor and used to calculate the light extinction coefficient $\left(\mathrm{K}_{\mathrm{d}}\right)$. Secchi depth was measured at both sites to estimate water clarity. Water samples for phosphorus analysis were collected at the 
near-surface and near-bottom with a Niskin bottle; samples for soluble reactive phosphorus (SRP) and total phosphorus were processed as described in the following paragraphs. Samples were stored on ice until transported to the laboratory, within 5 hours of collection. Water-quality sampling occurred between 0930 and 1330 during each sampling event.

The 12 sediment cores ( 6 per site) were incubated at AWRI in an environmental growth chamber, with the temperature maintained to match ambient near-bottom conditions in Silver Lake at the time of collection. The water column in three of the cores from each site was bubbled with nitrogen (with 5 percent carbon dioxide) to create buffered anoxic conditions, while the remaining three were bubbled with air to create oxic conditions.

Phosphorus release rate estimates were made using the methods outlined in Moore and others (1998), with minor modifications (Steinman and others, 2004, 2009). Briefly, a 60 milliliter $(\mathrm{mL})$ water sample was removed by syringe through the sampling port of each core tube at 0 hours (h), $12 \mathrm{~h}, 1$ day (d), $2 \mathrm{~d}, 4 \mathrm{~d}, 6 \mathrm{~d}, 8 \mathrm{~d}, 12 \mathrm{~d}, 16 \mathrm{~d}, 20 \mathrm{~d}, 24 \mathrm{~d}$, and $28 \mathrm{~d}$. Immediately after removal, a $20 \mathrm{~mL}$ subsample was refrigerated for analysis of total phosphorus, a $20 \mathrm{~mL}$ subsample was filtered through a $0.45 \mu \mathrm{m}$ membrane filter and frozen for analysis of SRP, and a $20 \mathrm{~mL}$ subsample was frozen for analysis of ammonium $\left(\mathrm{NH}_{4}^{+}\right)$. The $60 \mathrm{~mL}$ subsample was replaced with filtered water collected from the corresponding site in the lake; this maintained the original volume in the core tubes (at the beginning of the incubation).

Flux (phosphorus and nitrogen release rate) calculations were based on the change in water column total phosphorus or ammonium using the following equation (Steinman and others, 2004, 2009):

$$
R R=\left(C_{t}-C_{0}\right) \frac{V}{A}
$$

where

$R R \quad$ is the net total phosphorus or ammonium
release rate (positive values) or
retention rate (negative values) per unit
surface area of sediments,
is the total phosphorus or ammonium
concentration in the water column at
time $t$,
$C_{0}$ is the total phosphorus or ammonium
concentration in the water column at
time 0,

Release rates were calculated over the time period that resulted in the maximum apparent release rate, with the caveat that the initial and final samplings could not be consecutive sampling dates to avoid potential short-term bias. SRP concentration was nearly always below detection, precluding SRP flux calculations. Sediment elements (aluminum [Al], calcium $[\mathrm{Ca}]$, iron $[\mathrm{Fe}]$, magnesium $[\mathrm{Mg}]$ ) were measured on cores collected on August 20, 2014, and not used for nutrient release experiments.

\section{Diel Dissolved Oxygen Measurements}

Measurements of diel dissolved oxygen concentration (that is, daily variation in dissolved oxygen concentration) provided information on the redox status of Silver Lake, which can influence sediment phosphorus biogeochemistry (Boström and others, 1982). Specifically, hypoxic conditions (dissolved oxygen concentrations less than $2 \mathrm{mg} / \mathrm{L}$ ) can facilitate the release of phosphorus from sediments into the water column, as iron-bound phosphorus is dissociated under reducing conditions. Water column dissolved-oxygen concentrations were measured overnight, from late afternoon until mid-morning, to characterize in situ diel fluctuations in dissolved oxygen. Multiparameter water-quality sondes were suspended from an anchored buoy at the near-surface and near-bottom of the lake at the middle (L2) and south (L5) lake monitoring locations (fig. 2). The sondes were programmed to record data every 10 minutes. Diel dissolved oxygen concentrations were measured on four separate occasions over the study period: July 9, 2013; July 22, 2013; August 26, 2013; and August 29,2013 . Hourly wind data measured at the Mason County Airport (located approximately $21 \mathrm{mi}$ north from Silver Lake) were downloaded from the National Oceanic and Atmospheric Administration (NOAA) National Climatic Data Center (National Oceanic and Atmospheric Administration, 2013) for all diel dissolved oxygen events.

\section{Bioassay Study}

A nutrient bioassay was conducted July 22-25, 2013, to determine if nitrogen and/or phosphorus were limiting phytoplankton growth in Silver Lake. Sixteen 10-liter (L) carboys were filled with surface water at the middle lake monitoring site (L2) (fig. 2). Grab samples ( $\mathrm{n}=1$ unless otherwise noted) were taken from the water surface at the time of carboy filling for initial analysis of SRP, nitrate $\left(\mathrm{NO}_{3}\right)$, chlorophyll $a(\mathrm{n}=3)$, microcystin content, and phytoplankton community composition $(\mathrm{n}=3)$. The carboys were transported to the shore near the north groundwater monitoring well (W1) (fig. 2), and exposed to four nutrient treatments, each replicated four times: nitrogen addition (potassium nitrate $\left[\mathrm{KNO}_{3}\right], 10 \times$ ambient concentration); phosphorus addition (monopotassium phosphate $\left[\mathrm{KH}_{2} \mathrm{PO}_{4}\right], 10 \times$ ambient concentration); nitrogen plus phosphorus addition $\left(\mathrm{KNO}_{3}+\mathrm{KH}_{2} \mathrm{PO}_{4}\right.$, each $10 \times$ ambient concentration); and a control (no nutrient additions). A PVC frame was anchored in the nearshore zone (approximately $3.3 \mathrm{ft}$ water depth) and the carboys were secured to the frame in a way that allowed them to float just below the water surface. The carboys were randomly assigned positions on the frame (fig. 6). 

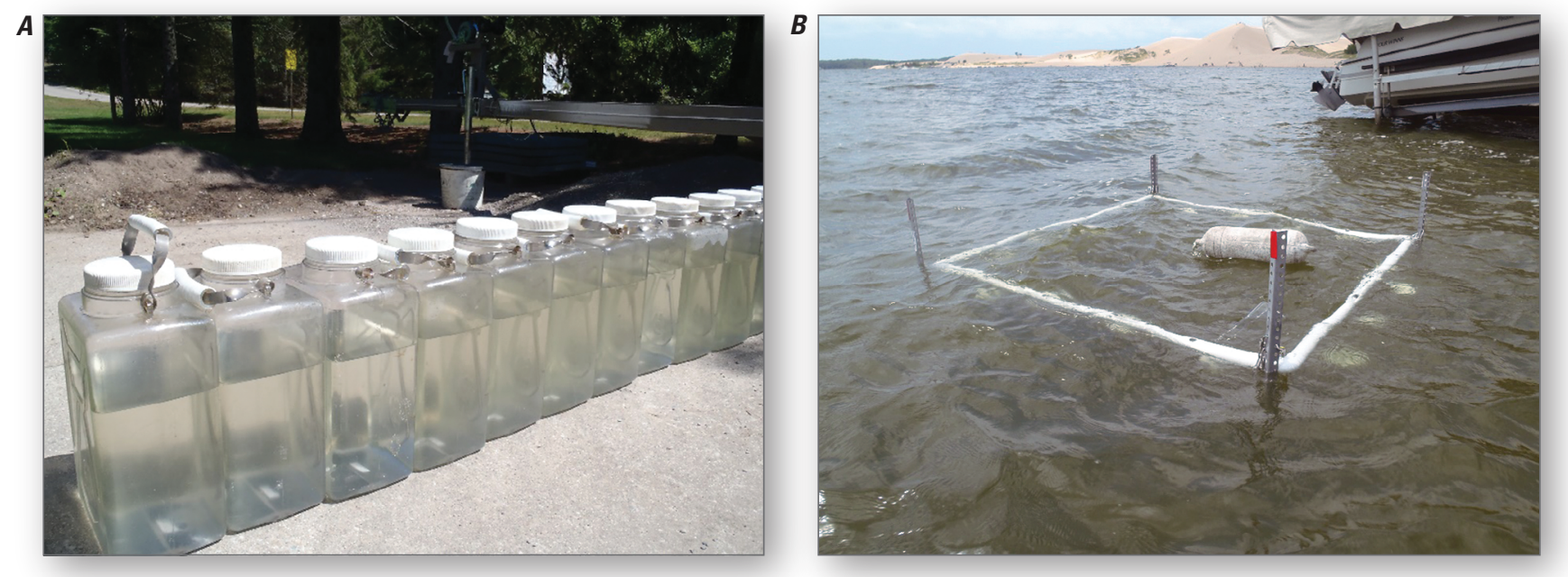

Figure 6. Bioassay carboys $(A)$ prior to final subsampling at the end of the incubation period, and bioassay incubation frame $(B)$ at its deployment location at the north end of Silver Lake, Oceana County, Michigan. (note submerged white caps from top of carboys). (Photo by Mary Ogdahl, Grand Valley State University-Annis Water Resources Institute, Muskegon, Michigan).

General water-quality parameters (dissolved oxygen, temperature, $\mathrm{pH}$, specific conductance, turbidity, TDS, and chlorophyll $a$ ) were measured at the water surface using a multiparameter water-quality sonde at the middle lake site at the time of collection and at the incubation location at the beginning and end of the bioassay.

After 72 hours, the carboys were retrieved and subsampled for analysis of phytoplankton taxonomic composition, chlorophyll $a$, SRP, nitrate, and microcystin content. Carboys were inverted 30 times prior to subsampling to ensure wellmixed subsamples. Subsamples for SRP were processed as described here. Subsamples for chlorophyll $a$ were filtered through glass-fiber filters, which were frozen until analysis (within 28 days). Nitrate $\left(\mathrm{NO}_{3}\right)$ subsamples were filtered through $0.45-\mu \mathrm{m}$ membrane filters and frozen until analysis. Subsamples for phytoplankton identification (1 L) were preserved with formalin to a final concentration of 4 percent. Phytoplankton subsamples were then allowed to settle for at least 48 hours in glass cylinders before the supernatant was removed and the concentrated phytoplankton volume (less than $125 \mathrm{~mL}$ ) was quantitatively transferred to an opaque sample bottle. An additional $2 \mathrm{~mL}$ of formalin was added to each sample upon transfer and samples were stored in opaque bottles until processing for microscopic analysis (see Laboratory Analysis, Bioassay Study section for more details).

\section{Tributary Monitoring and Streamgaging}

Three tributaries were routinely monitored to evaluate the surface water-quality and discharge from the watershed and upstream lakes. These include Hunter Creek (T1) (the largest tributary) and two unnamed smaller tributaries: the tributary at the State Park (T3) and the tributary at North Shore Drive (T2), located at North Shore Drive just north of the State Park campground (fig. 2, table 2). In addition, Silver Creek at the outlet of Silver Lake (T4) was routinely monitored to evaluate the surface-water quality and discharge leaving the lake (fig. 2). Water-quality samples were collected quarterly from November 2012 through September 2014, as well as during storm events, targeting 2-3 storm events annually. Two additional stream locations were monitored on three occasions in August and September 2014; these sites included Hunter Creek upstream from the Upper Silver Lake outlet (T5) and the Upper Silver Lake outlet at West Taylor Road (T6).

Streamflow, or discharge, was continuously measured and recorded at Hunter Creek at 5-minute intervals from October 1, 2012 through September 30, 2014 using a SonTek SL1200 acoustic doppler velocity meter (ADVM). This streamgage, Hunter Creek at North Shore Drive near Mears, MI. 0412220999, was located downstream from the North Shore Drive road crossing and near the mouth of the creek (A; fig. 2) as the upstream portions of the tributary were altered by a series of lagoons used for docking boats. Due to the proximity of the streamgage to the lake, an ADVM that is able to measure forward and reverse flow direction was installed. These reverse flow conditions occurred at Silver Lake when there were strong winds from the west.

To measure the amount of water leaving the lake, a continuous stage recorder was installed just upstream from the Silver Creek channel dam (B; fig. 2) that continuously measured and reported water stage at 5-minute intervals (Silver Creek at Silver Lake Dam near Mears, MI, 04122211). Given the known dimensions of the dam and the stage of the water, a discharge rating was developed that was then used to calculate discharge for Silver Creek (appendix 1). Discharge was measured at the smaller tributaries [tributary at the State Park (T3) and the tributary at North Shore Drive (T2)] during sample collection using a FlowTracker ${ }^{\circledR}$ acoustic doppler velocimeter (ADV) and established USGS protocols (fig. 2) (Turnipseed and Sauer, 2010). 
Water samples were collected from each of the tributaries following the USGS equal-width-increment (EWI) method or the grab sample method (U.S. Geological Survey, 2006) and were analyzed for nitrogen and phosphorus species, chlorophyll $a$, phytoplankton, turbidity, E. coli, and suspended-sediment concentrations (SSC) as well as $\mathrm{pH}$, dissolved oxygen, temperature, specific conductance, and turbidity. Suspendedsediment concentrations and E. coli data, collected as part of the tributary monitoring, are included in appendix 2 .

Average annual mean nutrient concentrations for the tributaries were calculated based on 2 years of data collection by summing the nutrient concentrations and dividing by the total number of samples. These concentration data were not flow-adjusted as only one site (Hunter Creek) had adequate discharge records for that calculation.

\section{Groundwater Monitoring and Flow}

An initial synoptic groundwater sampling was conducted using a temporary drive-point piezometer (DPP) at 17 locations in the near shore/beach environment circling the lake. The DPP was driven into the saturated zone beneath the lake and was then purged of three casing volumes. After purging, the shallow groundwater was sampled for basic physical water quality properties $(\mathrm{pH}$, specific conductance, dissolved oxygen, and temperature) and groundwater was field tested for orthophosphorus, nitrate, nitrite, ammonia, and chloride using Hach water-quality test strips. Groundwater collected using a DPP was also tested for E. coli. The results of the groundwater reconnaissance were then used to identify four locations for installation of monitoring wells for groundwater-level measurements and groundwater sampling.

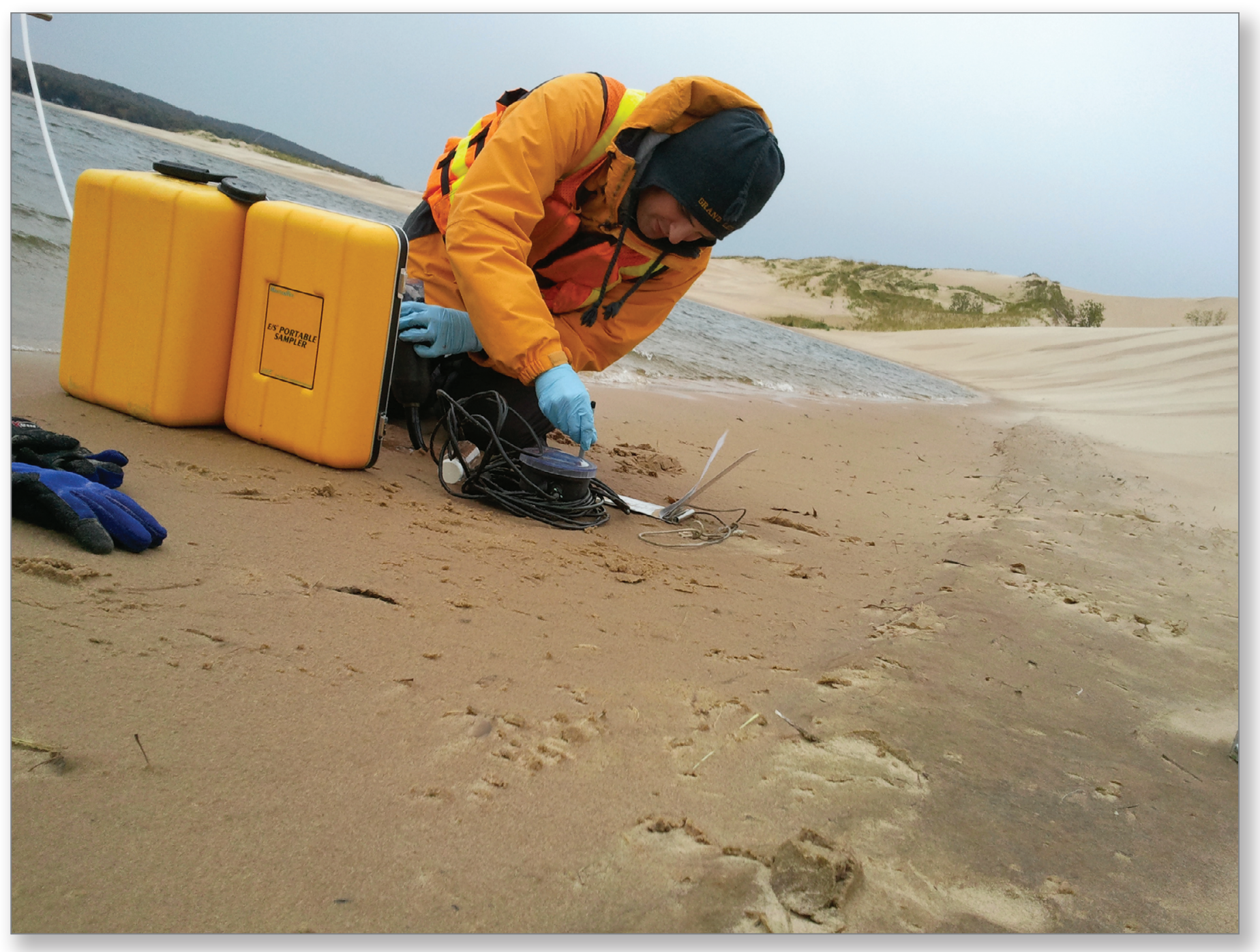

Synoptic groundwater sampling on the west side of Silver Lake. 
The results of the synoptic groundwater monitoring indicated likely locations around the lake where shallow groundwater was being influenced by septic system discharge. The relative rank of each synoptic-sampling site was computed by first determining the mean, and 1 and 2 times the standard deviation (SD) values for each of the measured property or constituent (nitrate, nitrite, ammonia, chloride, phosphate, $\mathrm{pH}$, dissolved oxygen, specific conductance, temperature, and E. coli bacteria). The relative percent difference from the mean for each property or constituent was then determined by subtracting the mean value from the individual observed value and then dividing by the mean value for that analyte. The values for sites were then scored for each parameter, with those less than $1 \mathrm{SD}$ from the mean receiving a zero, those from 1 to 2 SDs from the mean receiving a score of 1 , and those greater than 2 SDs from the mean receiving a score of 2 . The scores for all parameters were then added for each site and ranked. It was anticipated that higher-ranked sites or those with higher constituent concentrations and lower dissolved oxygen (when compared to the other groundwater samples collected) could indicate the likely presence of septic influence. The west and east wells were placed at sites that ranked in the bottom 25 percent of sites sampled for measurements indicating less potential for septic influence, while the north and south wells were placed at sites in the top 25 percent of sites where measurements indicated a likely septic influence.

As a result of the synoptic sampling, four 1.25 -in. diameter monitoring wells were installed on the north (T1), south (T4), east (T2), and west (T3) shorelines of Silver Lake (fig. 2). These wells were installed near the edge of the lake to depths $6.42 \mathrm{ft}$ (west well), $6.75 \mathrm{ft}$ (north well), $9.6 \mathrm{ft}$ (south well), and $10.2 \mathrm{ft}$ (east well). Groundwater pumped from these four shallow wells was monitored quarterly for 2 years, and water samples were analyzed for nitrogen and phosphorus species, turbidity, and E. coli, as well as $\mathrm{pH}$, dissolved oxygen, temperature, and specific conductance. The four wells were installed to characterize local groundwater flow by determining measured gradients of groundwater from recorded continuous water levels at 15-minute intervals at the east and west side of the lake, modeled after Garn and others (2006). Groundwater levels at all four wells were recorded pre-sampling and post sampling during each quarterly sampling event. E. coli data collected as part of the groundwater monitoring are included in appendix 2.

In addition, groundwater-flow data were supplemented by the installation of seepage meters, which were used to measure the flux of water across the sediment-water interface following methods described by Rosenberry (2008). On July 22 and 23, 2014, seepage meters were temporarily installed at 18 locations around the perimeter of Silver Lake.

In the northern section of the lake, several properties have tile drainage systems installed to assist in lowering groundwater levels. These drains remove groundwater that would have normally discharged to the lake through groundwater seepage and convey the groundwater directly to the lake. There were 38 visible drain tile outlets to the lake. Samples from five drain tile outlets were collected four times over the course of a year.

\section{Septic Systems as Sources of Nutrients}

Since lakeshore septic systems could be an important source of the phosphorus and nitrogen observed in shallow groundwater, the likely contribution of phosphorus and nitrogen from septic systems was computed using a model for septic transport originally published by Reckhow and others (1980) and adapted by Garn and others (1996). This model estimated phosphorus and nitrogen loading to Silver Lake from septic systems based on published literature values and by applying per-capita occupancy and likely soil-retention coefficients. Phosphorus and nitrogen loads were estimated based on the sum of all contributions from systems that were likely to impact the groundwater monitoring wells, as well as the flow from septic systems that was likely intercepted by surface water between the septic sources and the lake.

The following is the general septic mass expression (Garn and others, 1996; Reckhow and others, 1980) used to compute the mass of both phosphorus and nitrogen that directly load the lake or that load discrete surface-water bodies:

$$
M=E s \text { (number of per capita years) }(1-S R)
$$

where

$M \quad$ is the annual mass (load) of phosphorus or nitrogen entering the lake from septic systems, likely draining toward a groundwater-monitoring well (pounds per year),

Es $\quad$ is the export coefficient to each household septic tank system (per capita export from a household to a septic tank) (pounds per capita year),

number of per

capita years is the number of people using septic systems within $200 \mathrm{ft}$ of the lake, or surface-water body that drains to the lake, multiplied by the fraction of the year that the residence is occupied,

$S R \quad$ is the soil-retention coefficient representing the fraction of phosphorus or nitrogen retained between the septic-treatment system and the lake.

This septic model considers the number of residences and facilities within $200 \mathrm{ft}$ of the shore of the lake or surface water that drain to the lake. Septic systems further than $200 \mathrm{ft}$ from the lake still have an expected impact, but because of the longer travel distance and larger area of diffusion, the uncertainty in the estimation of load from these systems is too large to produce a reliable number. Furthermore, the model included only personal residences in the septic model estimates, not commercial facilities such as campgrounds and hotels within $200 \mathrm{ft}$ of the shoreline and Hunter Creek, as the septic model was not designed to accurately represent commercial facilities. If commercial facilities were included, the estimated nutrient loading from septic sources to the lake and Hunter Creek 
would be higher. However, it should be noted that commercial and residential septic sources further than $200 \mathrm{ft}$ from the lake are still captured in the nutrient budget from the groundwater well monitoring that includes nearby (within $200 \mathrm{ft}$ ) and diffuse (further than $200 \mathrm{ft}$ ) septic sources. As a result of these constraints, the amount of phosphorus and nitrogen being contributed directly to the lake or tributaries to the lake, as computed using this model, are likely a conservative estimation (an underestimate) of the actual phosphorus load coming from all septic tanks around the lake.

The number of facilities with septic systems was estimated by partitioning the area within $200 \mathrm{ft}$ of the lakeshore into drainage areas that likely impacted a groundwater monitoring point or a surface water body (based on groundwater gradient and flow direction) and then overlaying a parcel map (written communication Oceana County Equalization Department, 2012). For the south portion of Silver Lake there are 109 parcels, in the east there are 75 parcels, in the north there are 49 parcels, and in the west there are 0 parcels assumed to be impacting Silver Lake. Along the canals and directly adjacent to Hunter Creek there are 70 parcels, the tributary at North Shore Drive has 7 parcels. The drainage area of the tributary at the State Park was uncertain because it is routed underground. Based on an estimated drainage area, it was uncertain if there were any full parcels directly influencing the tributary at the State Park; therefore, an estimate of 0.5 parcels was used. Some of the parcels contributing to each area were not counted because aerial photographs (U.S. Department of Agriculture, 2014) ) indicated that they were empty lots likely purchased for lake access by residences that are not directly connected to the lake. Therefore, the number of household or hotel units used in the analysis can be different from the number of parcels identified (table 4).

Data on monthly occupancy were obtained from the Silver Lake Area Demographic Analysis (DeJong, 2015). Mean monthly occupancy rates were calculated by dividing the reported number of persons by the number of homes and cottages in the Silver Lake area. This number was multiplied by the expected number of units contributing to each area and the fraction of the year represented by each month to obtain capita-months. These monthly values were summed to produce a capita-year value for each contributing area. There were no parcels on the west side of Silver Lake in the Silver Lake dunes therefore the contribution from septic was assumed to be zero.

"Es," the per-capita export of phosphorus and nitrogen from a household to an onsite septic system, was estimated using previously published values. The median, 25 th percentile, and 75th percentile of phosphorus were calculated as reported in Reckhow and others (1980), 3.2, 2.6, and $3.3 \mathrm{lb} /$ capita-yr, respectively. Due to the variation in nitrogen monitoring data, the mean, maximum, and minimum values were calculated as reported in Reckhow and others (1980), 10.5, 4.7, and $18.1 \mathrm{lb} /$ capita-yr, respectively.

There are several other factors that influence if phosphorus and nitrogen from septic systems can reach Silver Lake.
These factors are typically related to the physical characteristics of the sites (groundwater gradient, depth to water table, and distance to surface water), properties of the soil (phosphorus and nitrogen adsorption capacity), and properties of the septic system (age of the system, designed use of the system, maintenance of the system). Properly working septic systems can remove from 23 to 95 percent of phosphorus and an average of 30 percent of nitrogen from wastewater (Robertson and others, 1998; Canter and Knox, 1986). However, soil has finite adsorptive abilities. The age of the system is directly related to the nutrient saturation of the soil that is intended to treat the waste, and therefore is directly related to treatment efficiency, with older systems becoming less efficient. In addition, older or poorly maintained septic systems may build up solids overtime, which can then migrate to the drain field and further negatively influence treatment efficiency by reducing the amount of time that wastewater is in the septic treatment process (Canter and Knox, 1986; Garn and others 1996). Inefficient settings for septic systems to remove phosphorus and nitrogen include settings where water tables are high, systems are placed on steep slopes, systems are placed in very coarse soil with little organic content, or systems are placed very close to surface water features, and some of these settings are applicable to Silver Lake.

To account for soil retention, the soil retention coefficient (SR; fraction of phosphorus or nitrogen retained in the soil), was estimated based on the described influencing factors. The SR can range from 0 to 1.0. If 100 percent of phosphorus and nitrogen reach surface water, the $\mathrm{SR}=0$; if there is no phosphorus and nitrogen that reaches the surface water, then the $\mathrm{SR}=1.0$. In this study, only parcels within $200 \mathrm{ft}$ of surface water (lake or stream tributary to the lake) were considered. The soil type within $200 \mathrm{ft}$ of Silver Lake is dominated by pipestone fine sand on a 0 to 4 percent grade (U.S. Department of Agriculture, 2015). This sand is defined by the USDA as "very limited" for use as a septic tank absorption field. This rating indicates that the soil may have a high saturated hydraulic conductivity $\left(\mathrm{K}_{\mathrm{sat}}\right)$ and a low depth to water table, which can affect the absorption of the effluent. The soil could also be underlain by loose sand and gravel at a depth of less than 4 feet below the septic system. These factors all indicate that pipestone fine sand may not adequately filter the effluent (U.S. Department of Agriculture, 2015). SR coefficients for these poor soils have been reported to be 0.2 to 0.6 , whereas failing septic systems have been reported using an SR of 0.25 (Garn and others, 1996). In an effort to be as conservative as possible when estimating septic contributions, and to match the observed data from groundwater monitoring, a range of SR values were used (table 4). Due to the uncertainty of septic function, age, and soil saturation, SR values were adjusted. Low values of SR were increased by 0.15 units to indicate the potential for better filtration (less phosphorus and nitrogen reaching the lake), while high SR values were decreased by 0.15 to indicate the potential for poorer filtration (more phosphorus and nitrogen reaching the lake). 


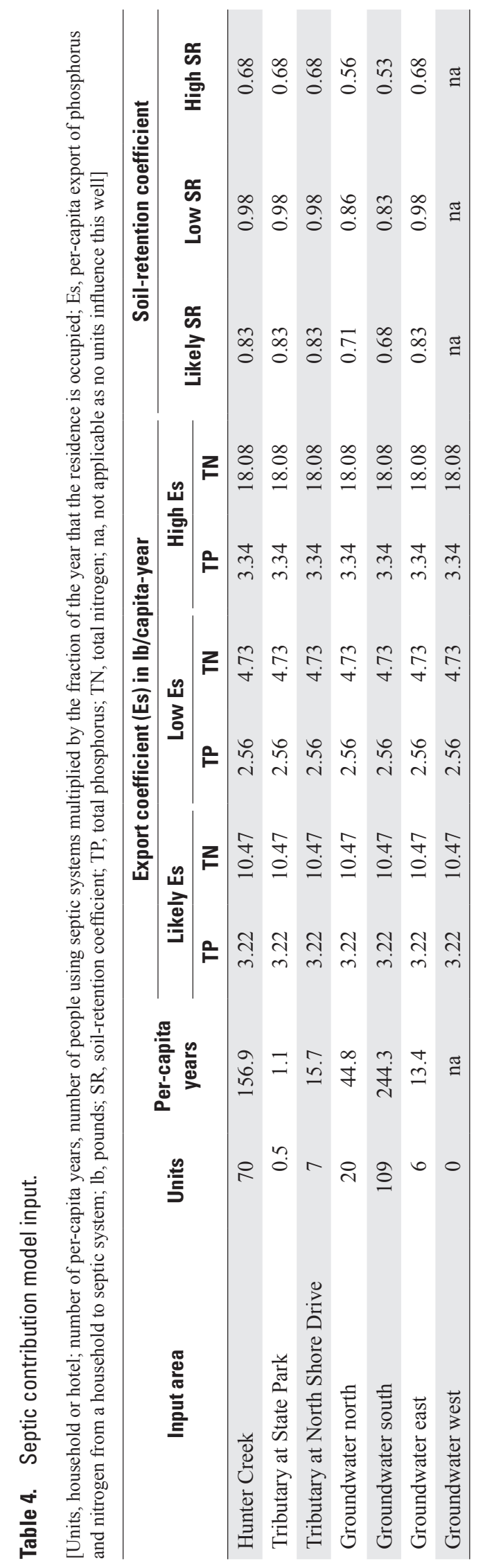




\section{Meteorology}

Meteorological data including precipitation, air temperature, soil moisture, relative humidity, soil temperature, total solar flux, wind direction, and wind speed were obtained from the Enviro-weather Network (Enviro-weather, 2015) Hart (hrt) and Ludington (ldt) stations. The Hart station was the primary station used for data analysis and is located at Asparagus Research Farm in Hart, Michigan, approximately $8.5 \mathrm{mi}$ northeast of Silver Lake (http://www.agweather.geo.msu.edu/ mawn/station.asp?id=hrt\&rt=60). In the event of data interruption at the Hart weather station, the data from the Ludington, Michigan (http://www.agweather.geo.msu.edu/mawn/station. asp?id $=1 \mathrm{dt} \& \mathrm{rt}=60$ ) weather station were used, which is located at Vanortwick Farms, approximately 17 mi northeast of Silver Lake. Data at both stations are recorded and reported hourly. There were 603 hourly measurements (of 19,704 total hourly measurements throughout the study period) when the Hart station was not operational due to maintenance issues and data were substituted with the Ludington weather station. During the period October 1, 2012-September 30, 2014, Silver Lake received an average of $31.9 \mathrm{in}$. of precipitation per year. The minimum, maximum, and mean temperatures during that time period were 24.3 degrees Celsius $\left({ }^{\circ} \mathrm{C}\right), 33.2{ }^{\circ} \mathrm{C}$ and $7.26^{\circ} \mathrm{C}\left(-11.7\right.$ degrees Fahrenheit $\left({ }^{\circ} \mathrm{F}\right), 91.8^{\circ} \mathrm{F}$, and $\left.45.1^{\circ} \mathrm{F}\right)$, respectively.

\section{Atmospheric Deposition Monitoring}

Atmospheric deposition can contribute both phosphorus and nitrogen to a system. Atmospheric nutrient deposition to Silver Lake was determined by the analysis of wet and dry deposition samples. During February 2014-September 2014, wet samples were collected after a precipitation event (rain or snow) and dry samples were collected after several days (from 5 to 7 days) following no precipitation. Samples were collected according to methods described in Robertson and others (2009). The atmospheric deposition station was constructed by securing a $2 \frac{1}{2} \times 2 \frac{1}{2} \mathrm{ft}$ table into the ground and attaching a stainless steel bowl on top of the table to which a clean polycarbonate sample bowl was attached prior to a sampling event. A wire mesh screen was secured over the sample bowl during periods of dry deposition sampling to minimize contamination from birds, leaves, and so forth. For wet deposition, samples were collected as soon as possible after the event in an effort to minimize evaporation and prevent contamination. A clean cover was placed on the sample collection bowl and the sample bowl was shaken until the sample was well mixed. Then, using a funnel, the sample water was decanted into a $125-\mathrm{mL}$ sample bottle using clean sampling techniques and preserved for shipment to the National Water Quality Laboratory (NWQL). Prior to sample collection, sample bottles were rinsed three times with sample water.

For dry deposition, a $250-\mathrm{mL}$ bottle of deionized water was poured into the sample collection bowl, a clean cover was placed on the sample collection bowl, and the contents were shaken until the sample was well mixed. A small amount of sample water was poured into the sample bottle (3 times) in order to rinse the bottles. Sample water was then decanted into a $125-\mathrm{mL}$ sample bottle using clean sampling techniques and preserved for shipment to NWQL.

Total precipitation (inches) was aggregated by season: winter (December, January, and February); spring (March, April, and May); summer (June, July, and August); and fall (September, October, and November). The seasonal total precipitation volume was estimated and multiplied by the nutrient concentration for the respective season. If there was a single measurement during that season, then the observed concentration was used. If there were multiple measurements during a season, the mean concentration was used for the season. This value was then used with a unit conversion factor to compute the pounds of phosphorus and nitrogen from wet deposition that fell on Silver Lake during each season. Annual wet deposition was then computed by summing the seasonal deposition.

Phosphorus and nitrogen mass from dry deposition were computed based on the measured concentrations, the volume used to suspend the mass $(0.25 \mathrm{~L})$, and the open area of the collection bowl. Mass per unit area of the collection bowl was extrapolated to the area of Silver Lake, and mass per area was divided by the time to obtain the rate in pounds per day of dry deposition on the lake. Seasonal dry deposition (pounds per season) was computed by multiplying the number of dry days (to the nearest hour) in the season by the daily deposition rate for each nutrient. No dry deposition samples were collected during the winter; therefore, winter dry deposition rates were estimated by applying the ratio of mean wet to mean dry deposition in spring, summer, and fall to the mean wet deposition that was measured in the winter. The resultant rate was used for winter dry deposition. If only one measurement was made, then that concentration was used to compute seasonal dry deposition rates. If multiple concentrations of dry deposition were measured during a season, the mean concentration was used to compute seasonal dry deposition rates. Annual dry deposition was computed by summing the seasonal dry deposition rates.

\section{Waterfowl}

The mass of nitrogen and phosphorus deposited by waterfowl also was estimated. Weekly average counts of Canada geese and mallards for Oceana County were obtained from eBird (eBird, 2014). The mean count is the mean count of birds from reported observations within Oceana County. This number indicates the mean number of birds expected to be observed on any day during that week, wherever the species is encountered in the county, although the mean is likely an underestimate because bird densities will typically be higher near water. Each weekly number was multiplied by the number of days attributed that week in the eBird data. The resultant values for bird counts were multiplied by published values for deposition of phosphorus and nitrogen by each bird species (Manny and others, 1994). Resultant loads were determined 
in pounds of phosphorus and nitrogen per year. Because it represents a solid mass (not a mass delivered in water), this load was input into the BATHTUB model as an addition to the atmospheric deposition value.

\section{Lawn Runoff}

The mass of nitrogen and phosphorus from lawn runoff was estimated using previously measured values from lake studies conducted in Wisconsin (Garn, 2002). Published mean runoff nutrient concentrations were weighted based on estimated fertilization patterns which were based on existing land use and on observed new lawns/construction around the lake where phosphorus fertilizer could likely be applied. The fertilizer utilization patterns for Silver Lake were estimated as 10 percent of fertilizer from unfertilized forest (representative of the SLSP), 50 percent unfertilized lawn (representing lawns around the lake that do not fertilize), 35 percent nonphosphorus fertilized lawns, (representing lawns that fertilize with regulated nonphosphorus fertilizer), and 5 percent regular phosphorus fertilized lawn (representing new lawns legally able to use standard phosphorus-containing fertilizer). Runoff rain events were those where greater than 0.3 in. of rain fell continuously. The data presented here assume that 25 percent of the rain that fell moved to the lake as runoff. This value falls in the middle of minimum and maximum percentages of runoff from precipitation that has been previously reported (Hunt and others, 2006; Garn, 2002).

\section{Water Budget}

A water budget was developed for Silver Lake to evaluate the various components of the hydrologic cycle and their relation to the lake. In addition to improving our understanding of the water cycle in Silver Lake, the information is important to identifying the key pathways that deliver nutrients to Silver Lake. In its simplest form, the water budget equation is a balance between the flow into and the flow out of a study unit. In this case the study unit was Silver Lake and the specific water balance equation used for Silver Lake was as follows:

$$
E T+\Delta S+Q_{\text {out }}^{S W}+Q_{\text {out }}^{G W}=P+Q_{\text {in }}^{S W}+Q_{\text {in }}^{G W}
$$

where

$\begin{array}{cl}E T & \text { is the evaporation from the lake, } \\ \Delta S & \text { is the change in storage of the lake, } \\ Q_{\text {out }}^{S W} & \text { is the loss of lake water to surface water, } \\ Q_{\text {out }}^{G W} & \text { is the loss of lake water to the groundwater, } \\ P & \text { is precipitation on the lake, } \\ Q_{\text {in }}^{S W} & \text { is the gain from surface water tributaries } \\ Q_{\text {in }}^{G W} & \text { is the gain of groundwater into the lake }\end{array}$

Each of these components was measured during the course of the study. For this analysis, a time period of October 1, 2012-September 30, 2014, was examined.

\section{Change in Storage}

The change in storage for the lake accounts for changes in the volume of the lake during the study. The lake volume change was estimated using the mean monthly gage height for the beginning and end months of the study period from the Hunter Creek gage. This was because the gage height was collected right at the river mouth confluence with the lake. The mean monthly lake stage was $586.5 \mathrm{ft}$ above North American Vertical Datum of 1988 (NAVD 88) in October 2012 and also in September 2014. As a result, there was no net storage change in the lake for that time period. This was expected as the lake stage is controlled through the operation of the Silver Lake Dam located $0.75 \mathrm{mi}$ downstream from Silver Lake on Silver Creek. Seasonally, there are storage changes that occur as the dam that controls the lake level is adjusted to lower the water level in the late fall and winter and then raise the water level in the late spring and summer. This equates to a storage loss in the fall and winter and a storage gain in the spring and summer.

\section{Precipitation}

During October 1, 2012-September 30, 2014, a total of 64.1 in. of precipitation fell in Hart, Mich., and it was assumed that the same amount fell on Silver Lake. The 1981-2010 mean annual precipitation for Hart, Mich., was 36.54 in. (National Oceanic and Atmospheric Administration, 2013) or would be 73.08 in. for 2 years. The precipitation measured during our study was below the long-term mean, indicating drier conditions than normal. Assuming a surface area of 672 acres, the total volume of precipitation that the lake received is estimated to be $1.56 \times 108$ cubic feet $\left(\mathrm{ft}^{3}\right)$.

\section{Evaporation}

Estimates of evaporation from the lake were derived from the parameters measured at the climate stations in Hart and Ludington. Previous studies indicate that when using data from a climate station not located on the lake (Winter and others, 1995, Rosenberry and others, 2004) the Jensen-Haise method (Jensen and Haise, 1963) produces results that match favorably with energy budget estimates of evaporation. The data required for developing an evaporation estimate were the daily maximum temperature, daily minimum temperature, and solar radiation. The evapotranspiration package for $\mathrm{R}$ (Guo and Westra, 2015) was used to process the climate data and return an estimated daily evaporation in millimeters. These daily estimates were summed and reported as total evaporation in inches. In addition to the climate data, some equation constants were required to estimate evapotranspiration, which 
included elevation of the lake (586.5 ft), latitude of the lake in radians $(0.7621)$, latent heat of vaporization $\left(2.45 \frac{\mathrm{MJ}}{\mathrm{kg}}\right)$, and the solar constant $\left(0.0820 \frac{\mathrm{MJ}}{\mathrm{m}^{2} \times \min }\right)$, where MJ equals megajoules, $\mathrm{kg}$ equals kilogram, $\mathrm{m}^{2}$ equals square meter and $\mathrm{min}$ equals minute. The lake was observed to be ice-covered from December through March during the study, so lake evaporation estimates were assumed to be zero during those months. The total evaporative loss estimated for the period October 1, 2012-September 30, 2014, was 50.7 in. from the lake. Assuming a surface area of 672 acres for the lake, the evaporative loss is estimated to be $1.24 \times 10^{8} \mathrm{ft}^{3}$.

\section{Surface-Water Inflow and Outflow}

Surface water serves as a pathway to both remove and deliver water to Silver Lake. For the removal of water from the lake there was one outflow, Silver Creek, at the southern end of the lake that connects Silver Lake to Lake Michigan (fig. 2, table 2). The Silver Lake Dam is located approximately $0.75 \mathrm{mi}$ downstream from Silver Lake and is used to regulate the lake level on Silver Lake. To estimate flow leaving the outlet, the reservoir upstream from the control structure was instrumented to measure the gage height of the water. A rating for the dam that relates gage height to flow was developed using the gage height information and the geometry of the structure. A description of the process for developing the rating for the dam can be found in appendix 1. Using that rating, the estimated total volume of water that left Silver Lake through Silver Creek from October 1, 2012 to September 30, 2014, was estimated to be $1.39 \times 10^{9} \mathrm{ft}^{3}$.

Three surface-water tributaries that contributed flow to Silver Lake included Hunter Creek, the tributary at the State Park, and the tributary at North Shore Drive (fig. 2, table 2). For the period October 1, 2012-September 30, 2014, an estimated total of $7.92 \times 10^{8} \mathrm{ft}^{3}$ of water entered Silver Lake from Hunter Creek based on information from the streamgage. The two other tributaries were monitored at various times throughout the study but were not continuously monitored. The tributary at North Shore Drive was measured 5 times and the tributary at the State Park was measured 10 times. The estimates of streamflow at the tributary at North Shore Drive ranged from 0.26 to 1.68 cubic feet per second $\left(\mathrm{ft}^{3} / \mathrm{s}\right)$ with a mean flow of $0.662 \mathrm{ft}^{3} / \mathrm{s}$. Using the mean streamflow and applying that to the 2-year period of study, results in an estimated contribution of $4.18 \times 10^{7} \mathrm{ft}^{3}$. Similarly, estimates of streamflow at the tributary at the State Park ranged from 0.79 to $1.54 \mathrm{ft}^{3} / \mathrm{s}$ with a mean streamflow of $0.993 \mathrm{ft}^{3} / \mathrm{s}$. Using the mean streamflow and applying that to the 2-year period of study results in an estimated contribution of $6.27 \times 10^{7} \mathrm{ft}^{3}$.

\section{Groundwater Inflow and Outflow (Flux)}

Groundwater also may serve dual roles as a pathway to remove or contribute water to Silver Lake. Several methods were used to understand the role of groundwater in Silver Lake. Based on the water levels collected at shallow piezometers and estimates of flux from seepage meters and discrete temperature sensors, the lake did not appear to be losing water to the aquifer. Rather, groundwater seemed to be contributing water to the lake.

An attempt was made to quantify the flux to the lake using the water-level data collected at the four monitoring wells around the lake (see appendix 3). Complexities associated with incomplete water-level data for part of the study period and the heterogeneity in groundwater hydraulic properties resulted in flux values that were not consistent with the other components of the water budget. Therefore, to maintain a balance with the other variables in the water budget equation, the groundwater inflow was set to the difference between the sum of the loss terms ( $E T$, $\left.Q_{\text {out }}^{G W}\right)$ and the sum of the remaining input terms $\left(P, Q_{i n}^{S W}\right)$. The result was a net contribution of $4.65 \times 10^{8} \mathrm{ft}^{3}$ for the period from October 1, 2012 to September 30, 2014.

For the purposes of the BATHTUB model, the groundwater flux was refined into different input sources. In the northern section of the lake, five drain tiles were measured (out of 38 visible drain tiles). A mean flow rate was estimated from these sampling events and used to estimate a mean annual flow of $5.04 \times 10^{6} \mathrm{ft}^{3}$. Extrapolating that value to the 2-year period of study yields a total flow of $1.01 \times 10^{7} \mathrm{ft}^{3}$.

The groundwater component of the water budget was further refined by quadrant of the lake. Silver Lake was divided into four quadrants on the basis of the four shallow wells installed to monitor groundwater-nutrient concentrations (fig. 3-2). To distribute groundwater flux by quadrant, the mean seepage per quadrant was multiplied by the length of shoreline in that quadrant to get a perimeter-weighted mean flux. Each quadrants' perimeter-weighted mean flux was divided by the sum of the perimeter-weighted mean fluxes to get a relative percentage of how much water is contributed by each quadrant. This percentage was then multiplied by the total groundwater contribution to obtain the estimated flux by quadrant. When broken down by quadrant, the estimated total groundwater flow for the 2-year study period was $1.21 \times 10^{7} \mathrm{ft}^{3}$ for the north quadrant, $4.98 \times 10^{7}$ $\mathrm{ft}^{3}$ for the east quadrant, $1.14 \times 10^{8} \mathrm{ft}^{3}$ for the south quadrant, and $2.79 \times 10^{8} \mathrm{ft}^{3}$ for the west quadrant (appendix 3).

Rates of groundwater flow around the lake were estimated using discrete seepage meters. On the basis of seepage measurements collected (appendix 3), specific discharge, or the apparent velocity of water moving through a section of aquifer ranged from 0.0042 to 1.3 feet per day (ft/d). The average linear velocity, defined as the specific discharge divided by the effective porosity of the medium, represents the velocity that water is actually moving through the porous medium. The average linear velocity was computed assuming an effective porosity of 20 percent (Fetter, 1994) and results in a range of groundwater flow rates of 0.014 to $4.3 \mathrm{ft} / \mathrm{d}$. It should be noted that the effective porosity represents the estimate of the connected pore space in the aquifer. This is different from the total porosity which was an estimate of the total pore space in a porous medium. A total porosity of 33 percent was used for the lakebed sediment when doing the temperature modeling of groundwater flux in appendix 3. 


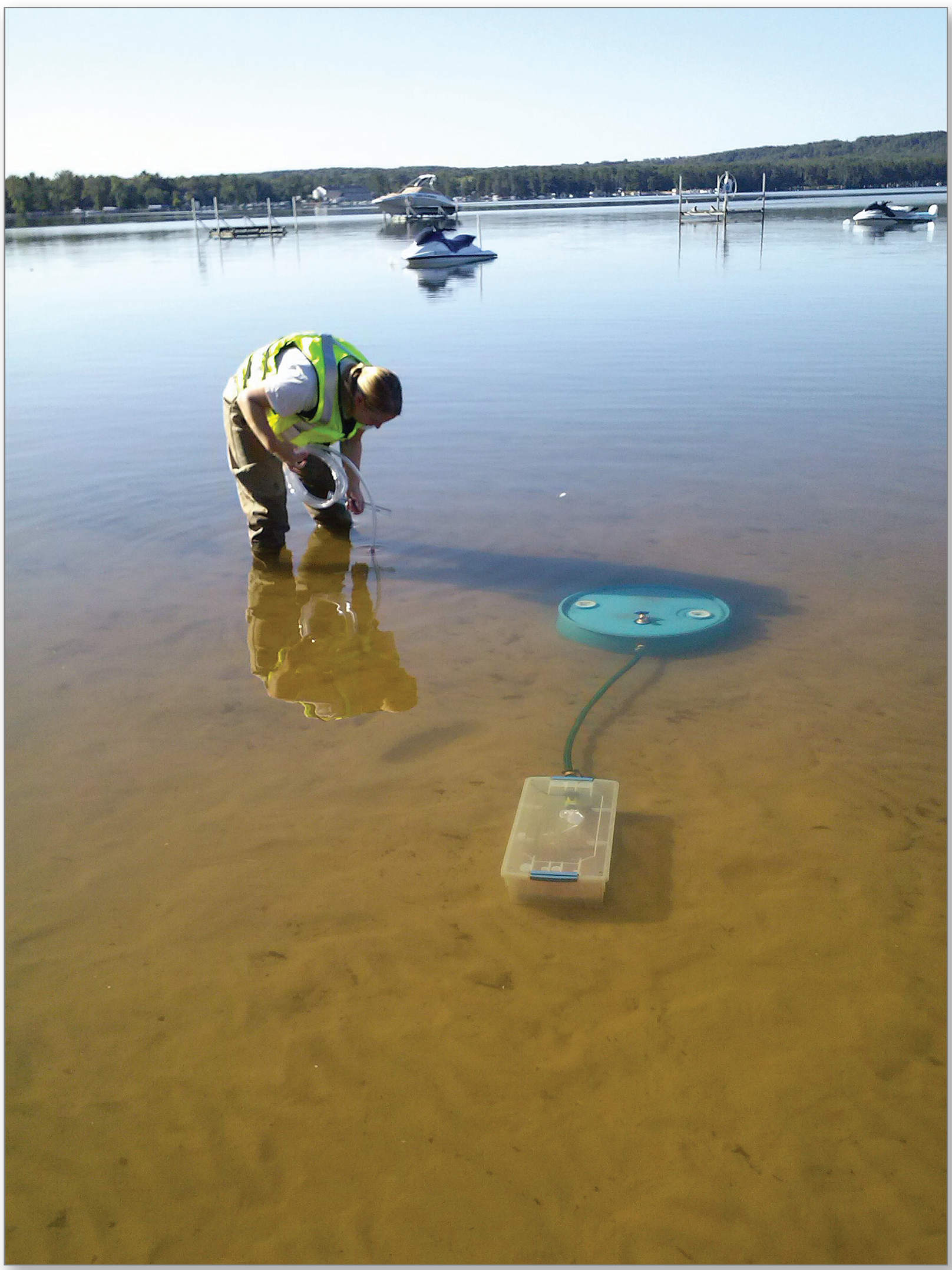

USGS staff measuring groundwater flux using seepage meters in Silver Lake. 


\section{Laboratory Analysis}

\section{U.S. Geological Survey National Water-Quality Laboratory/ U.S. Geological Survey Sediment Laboratory}

All water samples collected by the USGS were analyzed by the NWQL located in Denver, Colorado, in accordance with analytical procedures, holding time requirements, and quality assurance procedures as described in the USGS methods of analysis by the U.S. Geological Survey National Water Quality Laboratory (Fishman, 1993); determination of inorganic and organic constituents in water and fluvial sediments ).

All sediment samples collected by the USGS were analyzed for SSC by the USGS Kentucky Sediment Laboratory located at the USGS Kentucky Water Science Center in Louisville. SSC analysis was conducted according to USGS methods and procedures, as described in the Quality Assurance Plan for the Kentucky Water Science Center Sediment Laboratory (Shreve and Downs, 2005; Guy, 1969).

\section{Non-U.S. Geological Survey Laboratories}

\section{Internal Nutrient Loading}

Water samples from internal nutrient loading sediment core incubations were analyzed in the AWRI laboratory for soluble reactive phosphorus (SRP), total phosphorus, and ammonium on a SEAL AQ2 discrete automated analyzer (U.S. Environmental Protection Agency, 1983). Values below detection were calculated as half the detection limit (SRP: $5 \mu \mathrm{g} / \mathrm{L}$, total phosphorus: $10 \mu \mathrm{g} / \mathrm{L}$, ammonium: $20 \mu \mathrm{g} / \mathrm{L}$ ).

\section{Sediment Metal Analysis}

Sediment elements were analyzed using inductively coupled plasma-atomic emission spectrometry according to EPA method 6010B (U.S. Environmental Protection Agency, 2007) at Trace Analytical Laboratory, Muskegon, Michigan. Sediment iron:phosphorus ratios were determined by weight using dry weight-normalized total phosphorus concentrations.

\section{Bioassay Study}

Nitrate $\left(\mathrm{NO}_{3}\right)$ subsamples were filtered through $0.45-\mu \mathrm{m}$ membrane filters and frozen until analysis. SRP was analyzed in the AWRI laboratory as described in Study Methods and Sampling Sites, Bioassay Study section. Chlorophyll $a$ was extracted using a combination of an organic solvent (90 percent acetone with saturated magnesium carbonate) and tissue grinding. Chlorophyll $a$ was analyzed using the phaeophytin correction method on a Shimadzu UV-1601 spectrophotometer following standard methods (American Public Health Association, 1992). Nitrate was analyzed by ion chromatography on a Dionex DX500 (American Public Health Association, 1998).

\section{Water-Quality Standards and Criteria}

The development of nutrient criteria for water quality is an important, albeit complicated, process. Several references for nutrient-related criteria have been compiled for Michigan inland lakes, as the MDEQ has yet to adopt numeric nutrient criteria standards for Michigan (table 5). In 2012, the MDEQ awarded a grant to Michigan State University to update the methods used to develop expected nutrient concentrations for inland lakes in an effort to further the development of numeric criteria (Michigan Department of Environmental Quality, 2013).

In 2000, the EPA published the recommended water-quality criteria for nutrients (nitrogen and phosphorus) for different ecoregions around the country (U.S. Environmental Protection Agency, 2000a, b). The criteria were established as guidelines for each State to use as a starting point in the development of their own nutrient criteria. According to the EPA ambient water quality criteria recommendations for lakes in Ecoregion VII, total nitrogen values greater than $0.66 \mathrm{mg} / \mathrm{L}$ and total phosphorus values greater than $0.015 \mathrm{mg} / \mathrm{L}$ would indicate eutrophic conditions in the lake. The EPA ambient waterquality criteria recommendations for tributaries in Ecoregion VII for total nitrogen and total phosphorus are 0.54 and 0.033 $\mathrm{mg} / \mathrm{L}$, respectively (table 5). Since Michigan has yet to adopt numeric nutrient criteria, the EPA nutrient criteria for Ecoregion VII for lakes and rivers/streams was used in this report.

\section{Data-Quality Assurance}

Sample field blanks and field replicate samples were collected to assess for bias and precision, following methods described in the USGS National Field Manual (U.S. Geological Survey, 2006). Inorganic-grade reagent water was used as the sample medium for field blanks. Replicate and field blank samples were collected as part of the lake, tributary, groundwater, and atmospheric deposition monitoring.

For all field replicates, the relative percent difference (RPD) was calculated between the environmental and replicate samples for all major constituents using the formula below:

$$
R P D=\frac{\left|C_{e n v}-C_{r e p}\right|}{\operatorname{Mean}\left(C_{\text {env }}: C_{\text {rep }}\right)} \times 100
$$

where<smiles></smiles>

$\operatorname{Mean}\left(C_{e n v}: C_{r e p}\right)$ is absolute value of the difference between concentrations of the analyte in the primary environmental samples and the replicate sample,

is mean concentration of the analyte in the primary environmental and replicate sample. 
Table 5. References for Michigan water-quality nutrient criteria recommendations for lakes and rivers.

[*, indicates nutrient criteria used in this report; $\mathrm{mg} / \mathrm{L}$, milligrams per liter; $\mu \mathrm{g} / \mathrm{L}$, micrograms per liter; $\mathrm{TP}$, total phosphorus]

\begin{tabular}{|c|c|c|c|c|c|c|}
\hline Reference & $\begin{array}{l}\text { Water- } \\
\text { body } \\
\text { type }\end{array}$ & $\begin{array}{l}\text { Total nitrogen } \\
\text { (mg/L) }\end{array}$ & $\begin{array}{l}\text { Total } \\
\text { phosphorus } \\
\text { (mg/L) }\end{array}$ & $\begin{array}{l}\text { Chlorophyll a } \\
\text { ( } \mathrm{gg} / \mathrm{L}) \\
\text { (flourometric) }\end{array}$ & $\begin{array}{l}\text { Secchi } \\
\text { depth } \\
\text { (feet) }\end{array}$ & Notes \\
\hline $\begin{array}{l}\text { Michigan Department of } \\
\text { Natural Resources (1982) }\end{array}$ & Lake & Not available & $\begin{array}{c}0.021-0.050 \\
\mathrm{mg} / \mathrm{L}\end{array}$ & & & $\begin{array}{l}\text { Eutrophic trophic state } \\
\text { classification. }\end{array}$ \\
\hline Robertson and others (2003) & Lake & Not available & $\begin{array}{c}0.017-0.020 \\
\mathrm{mg} / \mathrm{L}\end{array}$ & & & $\begin{array}{l}\text { Eutrophic trophic classifi- } \\
\text { cation, U.S. Geological } \\
\text { Survey, Wisconsin. }\end{array}$ \\
\hline $\begin{array}{l}\text { U.S. Environmental } \\
\text { Protection Agency (EPA) } \\
(2000 a)^{*}\end{array}$ & Lake & $\begin{array}{l}0.66 \mathrm{mg} / \mathrm{L}^{*} \\
\text { (reported) }\end{array}$ & $0.015 \mathrm{mg} / \mathrm{L}^{*}$ & 2.63 & 10.93 & $\begin{array}{l}\text { Based on 25th percentile } \\
\quad \text { (EPA Ecoregion } 7 \text { criteria). }\end{array}$ \\
\hline $\begin{array}{l}\text { U.S. Environmental } \\
\text { Protection Agency (2000b)* }\end{array}$ & River & $0.54 \mathrm{mg} / \mathrm{L}^{*}$ & $0.033 \mathrm{mg} / \mathrm{L}^{*}$ & 1.54 & & $\begin{array}{l}\text { Based on } 25 \text { th percentile } \\
\text { (EPA Ecoregion } 7 \text { criteria). }\end{array}$ \\
\hline
\end{tabular}

For this study, RPD values greater than 20 percent were considered indicative of high variability of sample results. Overall, for all of the major chemical and sediment parameters analyzed by USGS as part of this study, the RPD values were less than 10.5 percent (ammonia, 0.3 percent; nitrate plus nitrite, 2.8 percent; total nitrogen, 5.9 percent; orthophosphate, 2.5 percent; total phosphorus, 7.5 percent; chlorophyll $a$, 10.5 percent; and SSC, 7.3 percent). Field replicates accounted for approximately 17 percent of all samples collected by the USGS as part of this study.
Field blank sample results indicate that there was no contamination that could be attributed to equipment cleaning, sample collection and handling, and laboratory handling. Almost all field blanks were at or below the detection limits for the major chemical and sediment parameters except for one total nitrogen concentration that exceeded the detection limit by $0.01 \mathrm{mg} / \mathrm{L}$, which is considered negligible for this study. Field blanks accounted for approximately 3 percent of all samples. 


\section{Lake Water-Quality Characteristics}

This section summarizes the key water quality findings from Silver Lake and presents data collected by AWRI and the USGS.

Silver Lake can be classified as a polymictic lake, meaning that the lake has frequent circulation and remains well mixed throughout the open-water period. The lake has a residence time (the amount of time it takes for water to replace the lake volume estimated by dividing the volume of the lake by the flow rate of water through the lake) of approximately 223 days. The temperature profiles collected throughout the five lake sampling sites confirmed that the lake did not exhibit thermal stratification in the open-water period or during iceon. During the winter months, the lake temperature varied minimally (within $2{ }^{\circ} \mathrm{C}$ ) and the lake did not appear to become anoxic during the day.

AWRI conducted a diel dissolved oxygen study to determine if, during the summer months, the lake turns hypoxic (dissolved oxygen less than $2 \mathrm{mg} / \mathrm{L}$ ) during the night but then mixes the next day due to wind-driven mixing or boat activity (see Diel Dissolved Oxygen section). Based on the USGS dataset, dissolved oxygen concentrations (measured during the day) in Silver Lake never decreased below $5.5 \mathrm{mg} / \mathrm{L}$ (59 percent saturation) during the study. The lowest dissolved oxygen concentrations typically were measured during summer months (June-August) and early fall (September). Supersaturated conditions (dissolved oxygen concentrations greater than 100 percent, which can indicate the presence of oxygen-producing algae in the water column) were commonly measured at all sampling sites, most frequently $3 \mathrm{ft}$ below the lake surface and throughout the photic zone; however, supersaturation infrequently occurred at the lake bottom.

The specific conductance of lake water is a measure of the ability of water to conduct an electrical current and is closely related to concentrations of the major ions (calcium, magnesium, sodium, and so forth), but not proportional to minor constituents of lake water such as iron, strontium, and manganese (Wetzel, 1983). Specific conductance values remained fairly consistent throughout the lake, ranging from 292 to 335 microsiemens per centimeter $(\mu \mathrm{S} / \mathrm{cm})$, with a mean lake conductivity value of $304 \mu \mathrm{S} / \mathrm{cm}$. The lowest specific conductance values were measured in June 2013 at all lake sites, and the highest values were measured during the March 2014 sampling event. Values greater than $600 \mu \mathrm{S} / \mathrm{cm}$ are generally considered indicative of water-quality impairment in lakes (Steinman and others 2011).

The $\mathrm{pH}$ in Silver Lake ranged from 7.8 to 9.5 standard units which is consistent with the range of $\mathrm{pH}$ observed in most open lakes that are well buffered (6 to 9 standard units) (Wetzel, 1983). The lowest $\mathrm{pH}$ values were measured during summer (July 2014) and spring (March 2013 and 2014), whereas the highest $\mathrm{pH}$ values were measured during the summer (July 2013) and early fall (September 2014) when productivity was the highest. The lowest $\mathrm{pH}$ values were measured at the near surface, photic zone, and near bottom sampling locations, whereas the highest $\mathrm{pH}$ values were measured only at the near surface sampling location.

During spring 2013 and 2014, water samples were collected from the middle deep basin (L2; fig. 2) and analyzed for common ions, color, hardness, TDS, and silica. The mean concentrations of calcium, magnesium, chloride, and hardness in Silver Lake were 37, 14, 8, and $151 \mathrm{mg} / \mathrm{L}$, respectively. These values indicate that Silver Lake is classified as having hard water, which is comparable to other lakes along the western coast and southern regions of Michigan (Fuller and Taricska, 2012). The water color in Silver Lake ranged from 5 to 15 platinum cobalt units (PCU) in the spring, which is on the lower end of the PCU color scale (laboratory test range from 0 to 500). Highly colored water has significant effects on aquatic plants and algal growth as colored water can limit the penetration of light which is very critical for the growth of aquatic plants and algae (U.S. Geological Survey, 2015a). Total dissolved solids and silica concentrations averaged 168 and $2 \mathrm{mg} / \mathrm{L}$, respectively.

The water clarity (transparency) was measured using a Secchi disk in Silver Lake and ranged from 2.5 to $16 \mathrm{ft}$. The lowest water clarity (Secchi depth of $2.5 \mathrm{ft}$ ) was measured in mid-November 2012 on the tail end of a summer with excessive algal blooms (prior to the start of this study). The highest water clarity (Secchi depth of $16 \mathrm{ft}$ ) was measured during the winter sampling event in March 2014 under approximately $2.5 \mathrm{ft}$ of ice. The mean water clarity for Silver Lake during the study period was a Secchi depth of $6.2 \mathrm{ft}$.

The minimum, maximum, and average nutrient concentrations measured in Silver Lake are presented in table 6. The lowest total phosphorus concentrations, $0.009 \mathrm{mg} / \mathrm{L}$, were measured during the winter sampling event in March 2014, and the highest total phosphorus concentrations, $0.053 \mathrm{mg} / \mathrm{L}$, were measured in mid-November 2012. Average total phosphorus concentrations collected from $3 \mathrm{ft}$ below lake surface $(0.03 \mathrm{mg} / \mathrm{L})$ and $3 \mathrm{ft}$ above lake bottom $(0.03 \mathrm{mg} / \mathrm{L})$ exhibited no variation throughout the water column. Silver Lake exhibited seasonal variation in phosphorus concentrations, however nitrogen did not exhibit the same pattern (fig. 7). Total phosphorus concentrations were lowest during the late winter/ early spring and increased until mid-summer when concentrations peaked and then continued to decrease through the fall and winter months. Silver Lake is classified as a eutrophic lake based on the average total phosphorus concentrations (table 7) and the phosphorus nutrient criteria recommendations listed in table 6 . 
Table 6. Statistical summary of nutrient and chlorophyll a concentrations measured from 2012-14 nutrient study in Silver Lake, Oceana County, Michigan.

[mg/L, milligrams per liter; $\mu \mathrm{g} / \mathrm{L}$, micrograms per liter; min, minimum; max, maximum; *bold typeface, identifies average concentrations that are in exceedance of the U.S. Environmental Protection Agency (EPA) ambient nutrient water-quality criteria recommendations for lakes and streams; na, not applicable]

\begin{tabular}{|c|c|c|c|c|c|c|c|c|c|c|}
\hline & & \multicolumn{3}{|c|}{ Total phosphorus (mg/L) } & \multicolumn{3}{|c|}{ Total nitrogen (mg/L) } & \multicolumn{3}{|c|}{ Chlorophyll a ( $\mu \mathrm{g} / \mathrm{L})$} \\
\hline & & Min & Max & Average & Min & Max & Average & Min & Max & Average \\
\hline Hunter Creek & & 0.016 & 0.034 & 0.022 & 0.91 & 1.47 & $* 1.07$ & 0.9 & 7.2 & $* 3.6$ \\
\hline Tributary at North Shore Drive & & 0.031 & 0.063 & $* 0.041$ & 0.65 & 1.35 & $* 0.95$ & 1.9 & 7.7 & $* 4.2$ \\
\hline Wet deposition & & 0.011 & 0.065 & 0.030 & 0.99 & 1.64 & 1.27 & na & na & na \\
\hline \multirow[t]{4}{*}{ Groundwater wells } & North & 0.012 & 0.018 & 0.016 & 0.05 & 0.17 & 0.1 & na & na & na \\
\hline & South & 0.014 & 0.118 & 0.059 & 0.13 & 4.84 & 1.85 & na & na & na \\
\hline & East & 0.004 & 0.008 & 0.005 & 0.06 & 0.14 & 0.11 & na & na & na \\
\hline & West & 0.004 & 0.011 & 0.007 & 0.10 & 0.63 & 0.32 & na & na & na \\
\hline
\end{tabular}

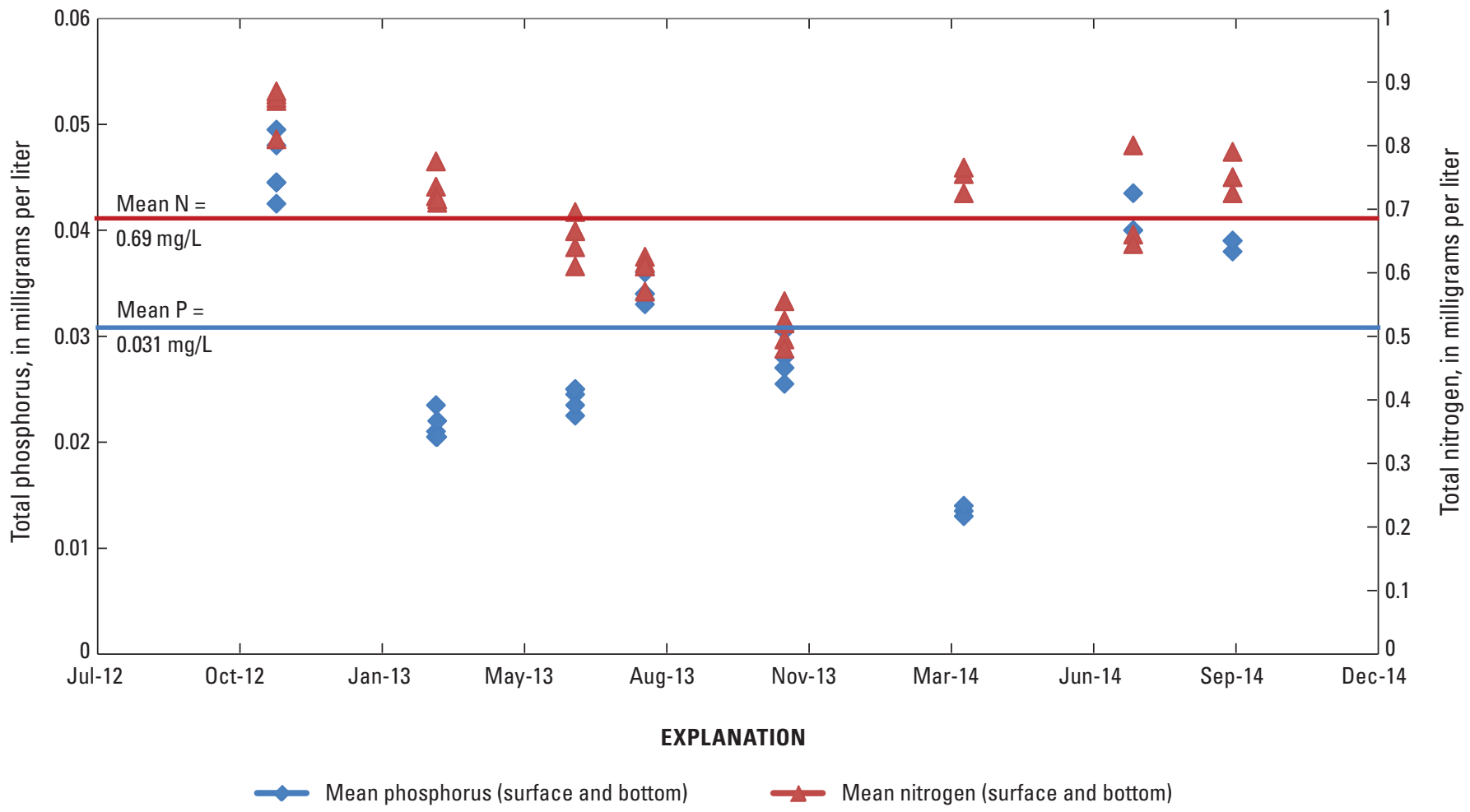

Figure 7. Total nitrogen and total phosphorus concentrations measured in Silver Lake Oceana County, Michigan, 2012 to 2014. (Mean nutrient concentration from samples collected near the surface of the lake and near the bottom; mg/L, milligrams per liter; Mean $\mathrm{N}$, mean nitrogen concentration; Mean $\mathrm{P}$, mean phosphorus concentration). 
Table 7. Lake Trophic State classification.

[Based on Robert Carlson's Trophic State Index (Carlson, 1977); TSI, Trophic State Index; <, less than]

\begin{tabular}{lcc}
\hline $\begin{array}{c}\text { Lake } \\
\text { trophic state }\end{array}$ & $\begin{array}{c}\text { Carlson's } \\
\text { TSI }\end{array}$ & Description \\
\hline Oligotrophic & $<40$ & $\begin{array}{c}\text { Limited supply of nutrients, very high } \\
\text { clarity and low algal densities, well } \\
\text { oxygenated in the deepest zones. } \\
\text { Mesotrophic }\end{array}$ \\
& $40-50$ & $\begin{array}{c}\text { Moderate supply of nutrients, moder- } \\
\text { ate clarity and algal densities, } \\
\text { oxygen can become depleted in } \\
\text { deepest zone.s }\end{array}$ \\
Eutrophic & $50-70$ & $\begin{array}{c}\text { Large supply of nutrients, low water } \\
\text { clarity and frequent algal blooms, } \\
\text { oxygen depletion in deeper zones. }\end{array}$ \\
Hypereutrophic & $70-100+$ & $\begin{array}{c}\text { Excessive nutrients, more frequent } \\
\text { algal blooms, fish kills. }\end{array}$ \\
\hline
\end{tabular}

Total nitrogen concentrations continually decreased after the initial sampling event on November 13, 2012, with the lowest total nitrogen concentrations, $0.44 \mathrm{mg} / \mathrm{L}$, recorded during the November 5, 2013, sampling event at all five lake locations. Average total nitrogen concentrations increased through the remainder of the study period. The highest total nitrogen concentrations, $0.98 \mathrm{mg} / \mathrm{L}$, were measured at the beginning of the study and during the March 2013 and 2014 sampling events. On average, total nitrogen concentrations collected from $3 \mathrm{ft}$ below lake surface $(0.67 \mathrm{mg} / \mathrm{L})$ and $3 \mathrm{ft}$ above lake bottom $(0.71 \mathrm{mg} / \mathrm{L})$ exhibited minimal variation throughout the water column. Total nitrogen concentrations in Silver Lake did not vary seasonally (fig. 7). It should be noted that even though total nitrogen concentrations did not exhibit seasonal variability in concentrations, both ammonia and nitrate concentrations peaked during the late winter sampling events in March, which is a common occurrence in eutrophic lakes in the Midwest (Wetzel, 1983). Also, during the late fall, organic nitrogen made up the bulk of total nitrogen in Silver Lake. Based on the EPA nutrient criteria recommendation for nitrogen in Ecoregion VII, the lake would be classified as eutrophic.

The ratio of nitrogen to phosphorus (N:P ratio) is related to the amount of primary production in the system (as measured by chrorophyll $a$ ), and when the N:P value falls below 14 or above 17 , the system will typically be limited by nitrogen or phosphorus respectively (Conley and others, 2009). This is because as the seasonal phosphorus and nitrogen concentrations in Silver Lake increase and decrease, the N:P ratio therefore varies seasonally throughout the study period. The N:P ratio for Silver Lake ranges from a low of 17:1 in the summer and fall, to a high of 56:1 in early spring (March), with a study-period mean N:P ratio of 22:1. The seasonal fluctuation in the $\mathrm{N}: \mathrm{P}$ ratio likely influences nutrient limitation and primary productivity (as indicated by chlorophyll $a$ concentrations) throughout the study period (fig. 8).

Chlorophyll $a$, the major pigment involved in photosynthesis in plants and eukaryotic algae, is an indicator of water quality and is frequently used as a proxy for algal biomass. Chlorophyll $a$ is often used to determine the trophic status

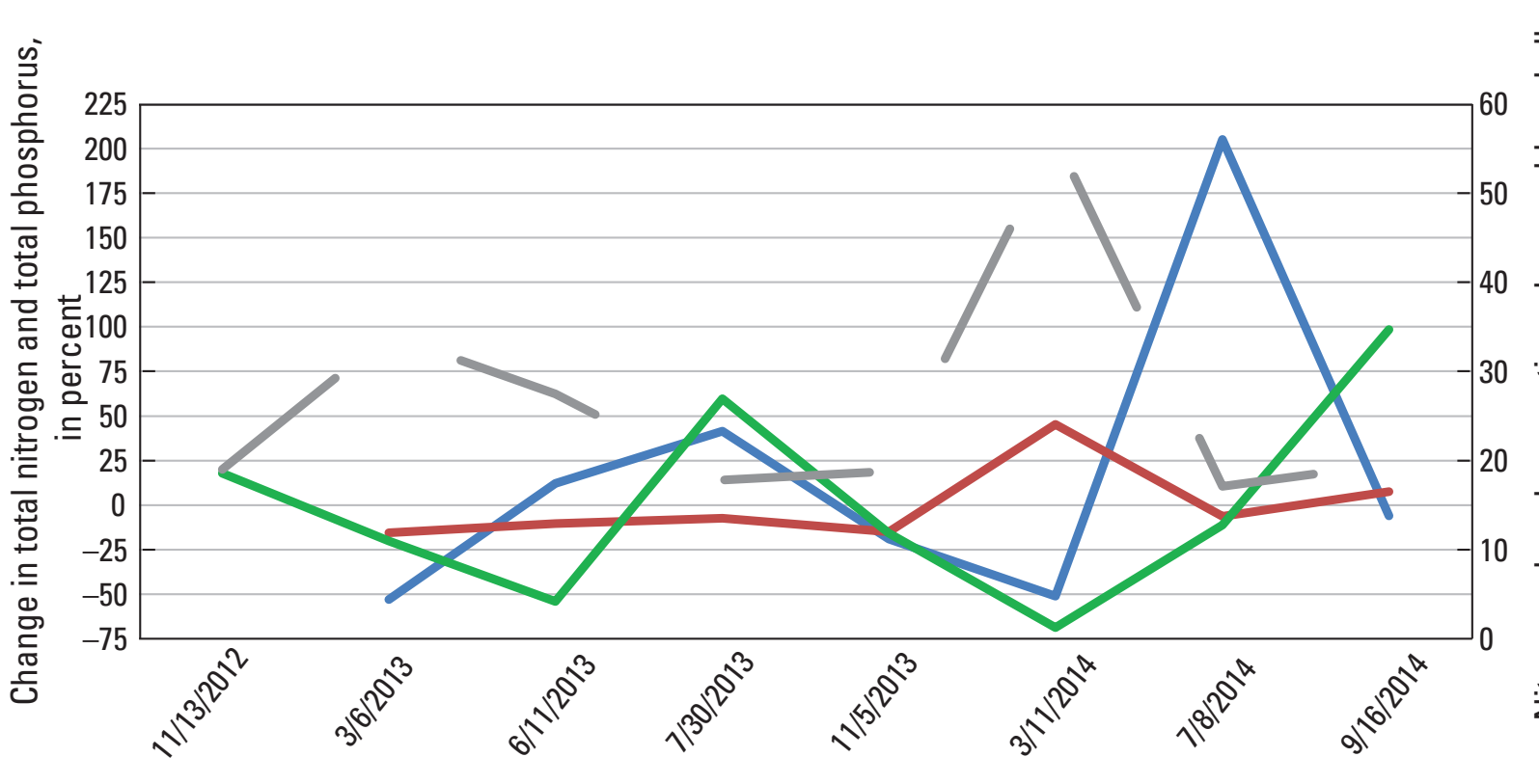

\section{EXPLANATION}

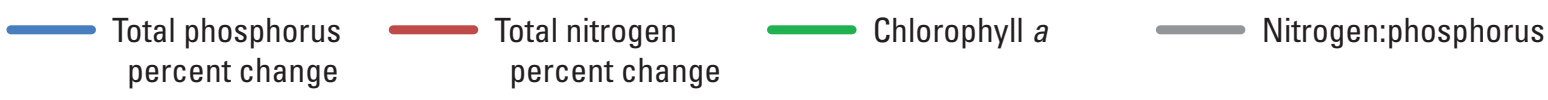

Figure 8. Nitrogen to phosphorus ratios in Silver Lake, Oceana County, Michigan, 2012 to 2014. 
of a lake, along with water transparency and total phosphorus. During this study, chlorophyll $a$ concentrations peaked in late summer and early fall (maximum chlorophyll $a$ value $38.9 \mu \mathrm{g} / \mathrm{L}$, at the north lake location) and were lowest (minimum chlorophyll $a$ value $0.7 \mu \mathrm{g} / \mathrm{L}$, at the south lake location) during the late winter and early spring months.

\section{Trophic Status and Lake Classification}

Lakes are often classified by their trophic status, which is an indicator of the amount of biomass or biological productivity in the lake. The trophic status of lakes can be compared and tracked over time to help evaluate lake response to factors such as nutrient enrichment, age, or the implementation of best management practices (BMPs). In 1977, Dr. Robert Carlson published one of the most frequently used biomass-related trophic state indices (TSI) that remains widely used today to classify lakes.

According to Carlson's TSI, values of less than 40 represent oligotrophic conditions (low productivity, low nutrient content, clear water); 40-50, mesotrophic conditions (moderate productivity with medium level of nutrients, commonly clear); and greater than 50 represent eutrophic conditions (high productivity [abundance of aquatic plants and (or) algae], and low transparency) (table 7). Although the concept of TSI ranges is simple, the interpretation can be complex because of the interdependency of chlorophyll $a$, total phosphorus, and Secchi-disk transparency, thus the TSI values computed from any of these three indicators may not necessarily be the same (Fuller and Taricska, 2012). The chemical and physical environment can influence particular indicators and the interrelation with one another (Wetzel, 2001). For this study chlorophyll $a$, Secchi depth, and the mean of near-surface and near-bottom total phosphorus concentrations were used to calculate TSI using the following equations (Carlson, 1977):

TSIsecchi $=60-14.41 * \ln ($ Secchi-disk transparency, in meters)

TSIchlor- $a=9.81 * \ln ($ chlorophyll $a$, in micrograms per liter $)+30.6$

TSIphos $=14.42 * \ln ($ total phosphorus, in micrograms per liter $)+4.15$

Mean TSI values were calculated for Silver Lake for each of the sampling events using Secchi depth, total phosphorus (mean value from near surface and near bottom samples, as well as a mean value among all lake sites), and chlorophyll $a$ and are presented in figure 9. All three TSI indexes in this study classified Silver Lake as eutrophic approximately 63 percent of the time (five sampling events); mesotrophic to slightly eutrophic approximately 25 percent of the time (two sampling events); and oligotrophic to slightly mesotrophic about 13 percent of the time (one sampling event). In March 2013, the TSI calculations using chlorophyll $a$ indicated that the lake was eutrophic when the other two indices indicated the lake was mesotrophic. Also in March 2014, the TSI calculations

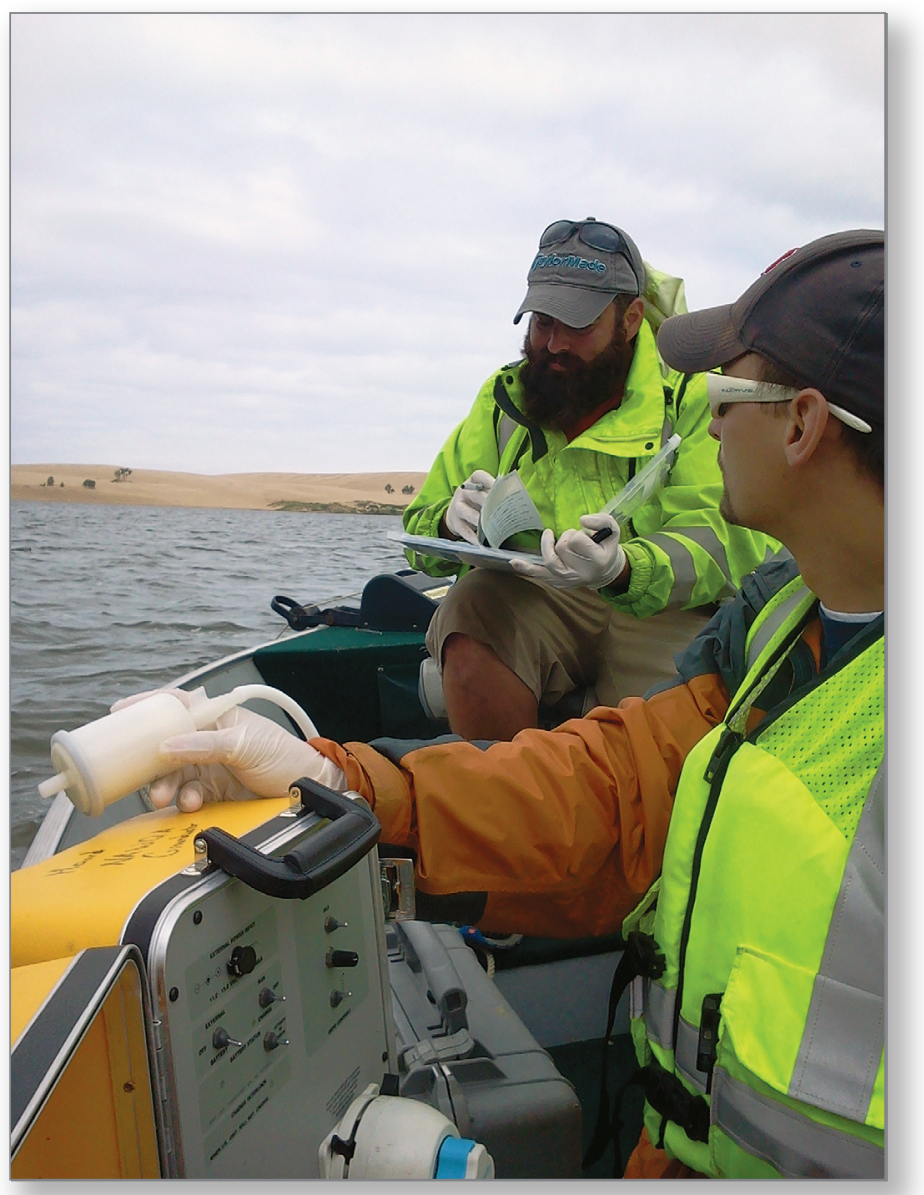

USGS staff sample water quality in Silver Lake.

using total phosphorus indicated the lake was mesotrophic when chlorophyll $a$ and Secchi disk depth indicated the lake was oligotrophic.

\section{"I suggest that for purposes of classification} priority be given to the biological parameters, especially the chlorophyll index, during summer, and perhaps to the phosphorus values in spring, fall, and winter, when the algae may be limited by factors other than phosphorus. These priorities would result in about the same index value during any season of the year (Carlson, 1977)."

Based on Carlson's recommendations (Carlson, 1977), phosphorus may be the better indicator to use during the spring sampling events, thus indicating that the lake was mesotrophic in March 2013 and 2014. 


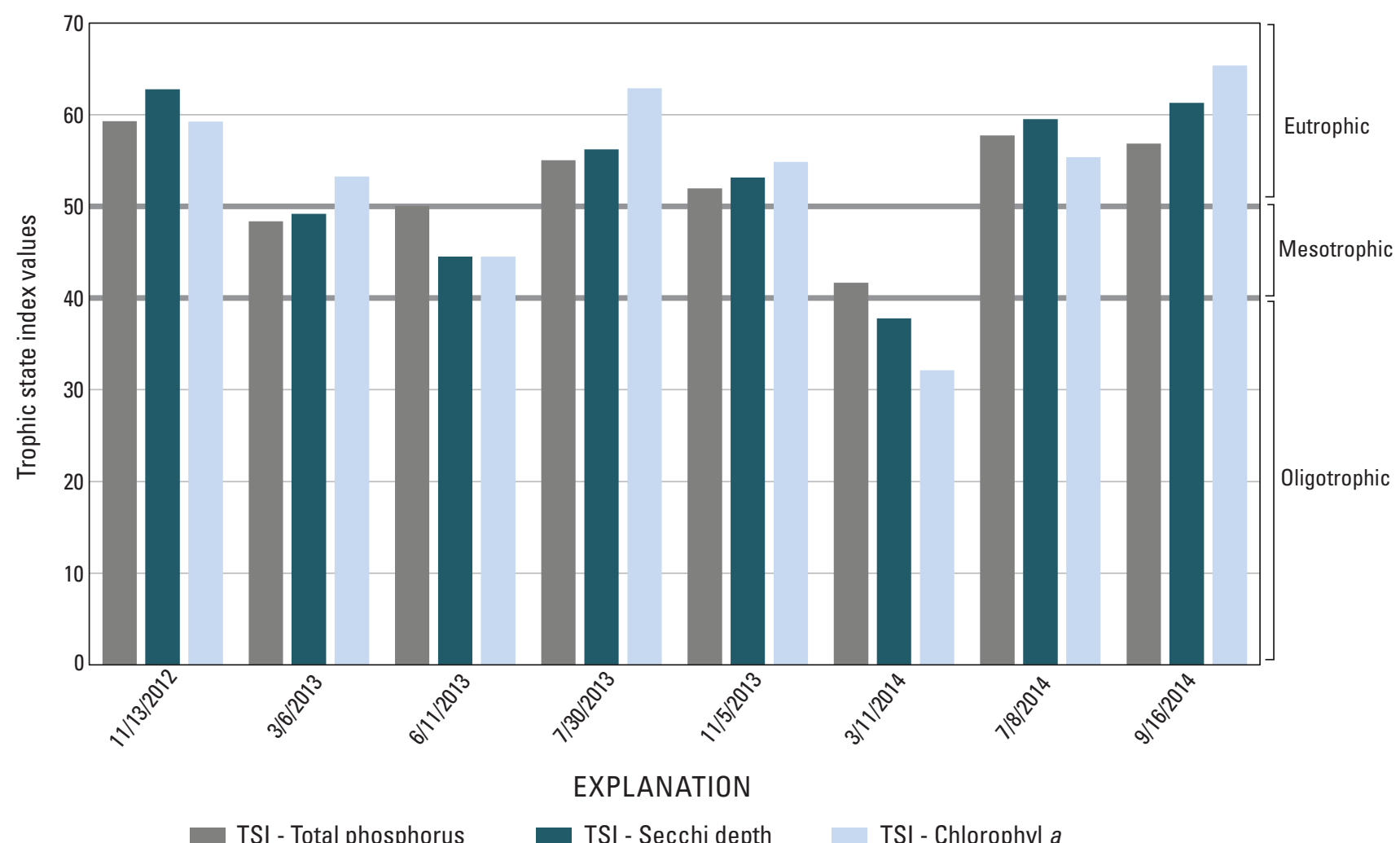

Figure 9. Trophic status of Silver Lake, Oceana County, Michigan, based on Carlson's Trophic State Index. (TSI, trophic state index; less than 40 represents oligotrophic conditions, 40-50 mesotrophic, greater than 50 represents eutrophic conditions).

\section{Bioassay Study Results}

Bioassay results indicated that algal growth in Silver Lake is colimited by nitrogen and phosphorus. Chlorophyll $a$ concentrations were statistically different among nutrient treatments (p-value $<0.001$ ). Algal growth was stimulated by the nitrogen plus phosphorus treatment, which had the highest mean chlorophyll $a$ concentration ( $32 \mu \mathrm{g} / \mathrm{L}$; fig. 10). The nitrogen treatment had the second highest mean chlorophyll $a$ concentration $(15 \mu \mathrm{g} / \mathrm{L})$, which was less than half of the nitrogen plus phosphorus treatment mean concentration. Mean chlorophyll $a$ concentration in the phosphorus treatment was not significantly different from the control concentration. Only the nitrogen plus phosphorus treatment resulted in a net increase in chlorophyll $a$ concentration relative to initial concentrations. These results indicate that algal growth in Silver Lake is colimited by nitrogen and phosphorus.

General water-quality conditions were similar among the recorded measurements taken at the time/location of water collection (that is, mid-lake) and at the incubation location (that is, north end of lake), confirming that incubation location conditions simulated the natural environment in the open lake. Values for water-quality variables were similar to those recorded during the August 20, 2013, core collection.

Results of the microcystin analysis and phytoplankton identification and enumeration are included in appendix 2.

\section{Diel Dissolved Oxygen}

Diel fluctuations in dissolved oxygen concentrations were evident in the near-bottom waters of the south (L5) and middle (L2) sites during the study period, although periods of hypoxia (dissolved oxygen less than $2 \mathrm{mg} / \mathrm{L}$ ) were rare (fig. 11). When reliable data were recorded, dissolved oxygen concentrations in near-bottom water were generally greater than $6 \mathrm{mg} / \mathrm{L}$ at both sites outside of the brief diel low dissolved oxygen period. The exception was the middle site (L2) on August 29-30, 2013, when dissolved oxygen concentrations were less than $5 \mathrm{mg} / \mathrm{L}$ during nearly the entire recording period (fig. 11C). Dissolved oxygen concentrations at the middle site fell below $2 \mathrm{mg} / \mathrm{L}$, at the near-bottom location, during the evening/ night hours of the three monitoring events; sensor malfunction resulted in missing data for the September 26-27, 2013, monitoring event (fig. 11D). A strong diel signal was recorded at the near-bottom of the south site during only one monitoring event (July 9-10, 2013), when concentrations fell below $3 \mathrm{mg} / \mathrm{L}$ for approximately 2.5 hours (fig. 11A). The near-bottom dissolved oxygen sensor at the south site made intermittent contact with the bottom sediments during the July 22-23, 2013, event rendering the data unreliable, and therefore the data are not shown in figure 11B. Near-surface dissolved oxygen concentrations were greater than $7 \mathrm{mg} / \mathrm{L}$ at both sites; the near-surface sensor at the south site malfunctioned on July 9-10, 2013, so data are 


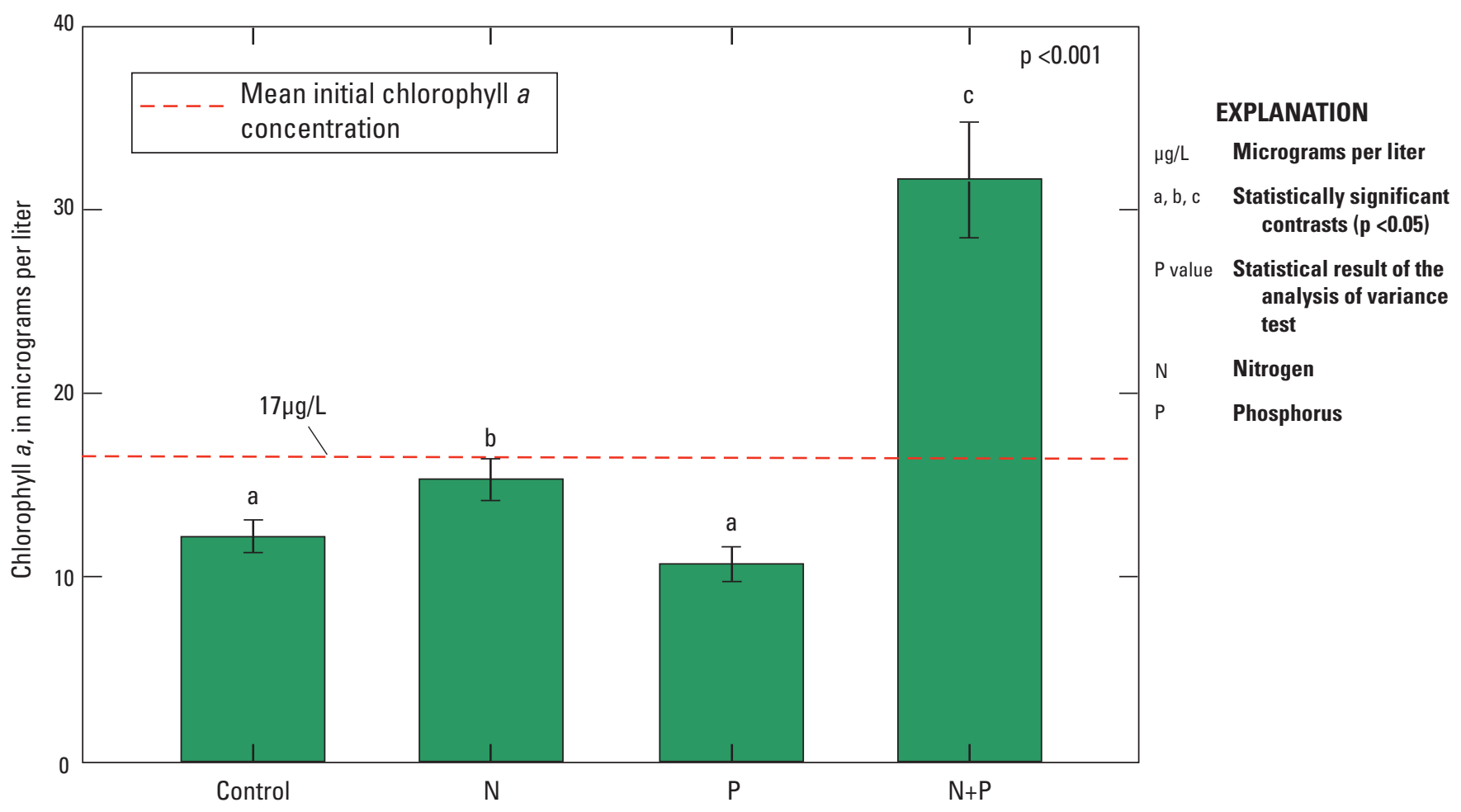

Figure 10. Mean (plus or minus standard deviation) chlorophyll a concentrations from the four bioassay treatments.

not shown in figure 11A. However, based on the other monitoring events, it is suspected that concentrations were similar to those recorded at the near-surface of the middle site.

Wind speed was about $10-20$ miles per hour $(\mathrm{mi} / \mathrm{h})$ during the first two diel dissolved oxygen monitoring events (fig. 11A, B) and less than $5 \mathrm{mi} / \mathrm{h}$ during the last two events (fig. 11B, C). No clear relation was evident between dissolved oxygen fluctuation and wind speed or direction.

These results point to (1) a lack of continuous hypoxic conditions at the times and locations of the two monitoring sites but (2) occasional periods of intermittent hypoxia (less than $2 \mathrm{mg} / \mathrm{L}$ ) during evening hours, especially at the middle site, from early July through late August. Although nearbottom data were missing at the middle site from the late September monitoring event, the near-bottom data from the south site indicate well-oxygenated conditions throughout the water column during that time (fig. 11D). Hence, the hypoxic or anoxic conditions necessary to support internal phosphorus loading in Silver Lake are rare. As shown by the sediment core incubation results (see Nutrient Loads, Internal Nutrient Loading section), Silver Lake sediments are expected to release very little or no phosphorus, regardless of redox state. 

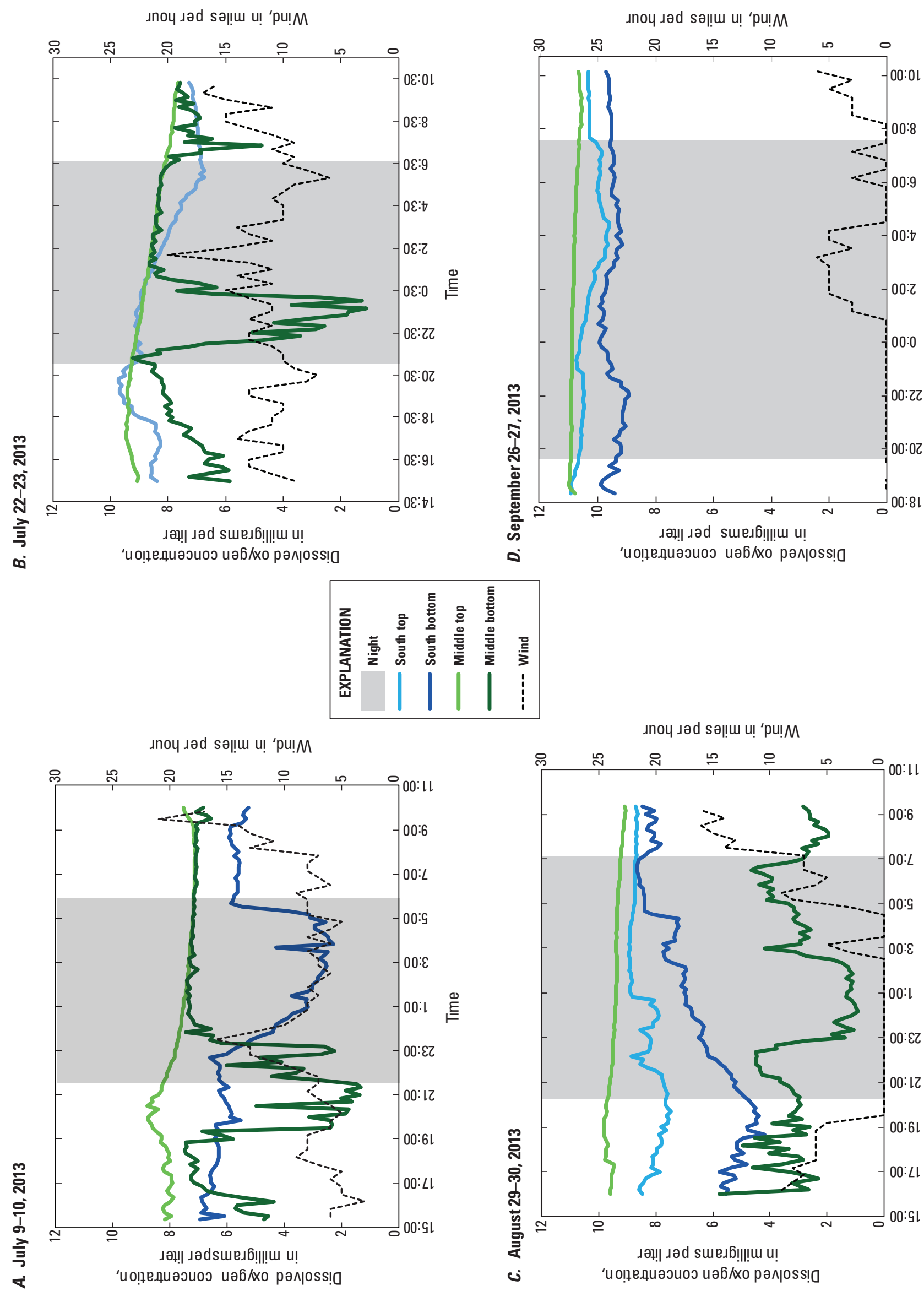

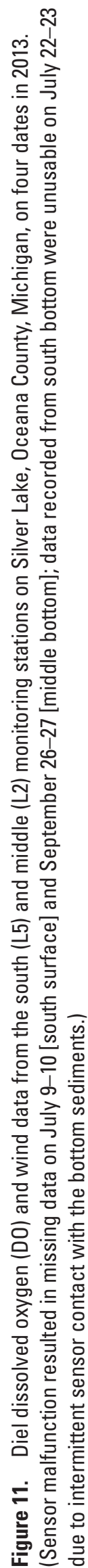




\section{Hydrology: Sources of Water and Nutrients}

Study results indicate that Silver Lake is colimited by both phosphorus and nitrogen, at the time when the bioassay was conducted. The average N:P ratio was found to be 22:1; however, it varied seasonally as phosphorus and nitrogen concentrations in the lake changed (fig. 8). As a result, both phosphorus and nitrogen are deemed critical nutrients in the development of algal blooms and lake eutrophication in Silver Lake. While this colimitation indicates that both nitrogen and phosphorus are needed to produce excessive algal growth during the summer months, it does not indicate that both nutrients need to be reduced to control algal blooms. Based on the bioassay study, management practices that reduce either nitrogen or phosphorus should be enough to limit excessive primary production in the summer months, and a reduction in both nutrients would likely impact magnitude (Harpole and others, 2011; Conley and others, 2009). To determine the sources of nutrients to Silver Lake, contributions from surface water (tributary inputs, including septic contribution to tributaries), groundwater (including septic), atmospheric deposition (wet and dry), waterfowl, lawn runoff, and internal loading from lake sediments were evaluated as described in the following sections.

\section{Sources of Water-Water Budget}

The water budget for Silver Lake can be visualized as a pie graph with individual components represented as a slice of the overall budget. Figure 12 illustrates the various components of the water budget by percentage of outflow and inflow over the 2-year study period. Water loss from Silver Lake is primarily the outflow of water from Silver Lake through Silver Creek which accounts for 91.9 percent of all water leaving Silver Lake. The remaining 8.1 percent is removed through evaporation. The primary contribution of water to Silver Lake is from Hunter Creek at 52.2 percent. Groundwater sources contribute 30.6 percent of inflow, precipitation contributes 10.3 percent, the tributary at the State Park contributes 4.1 percent, and the tributary at North Shore Drive contributes 2.8 percent. Runoff of precipitation from the land directly to the lake is assumed to be small and is considered as part of the groundwater input to the lake.

Further refining the water budget by season for the 2-year study period provides insight on the relative contribution of the various components at different times of year (fig. 13). The three largest components of the water budget remain the outflow of water from Silver Lake, the inflow of water from Hunter Creek, and inflow of water from groundwater sources. However, the relative amounts of each component vary by

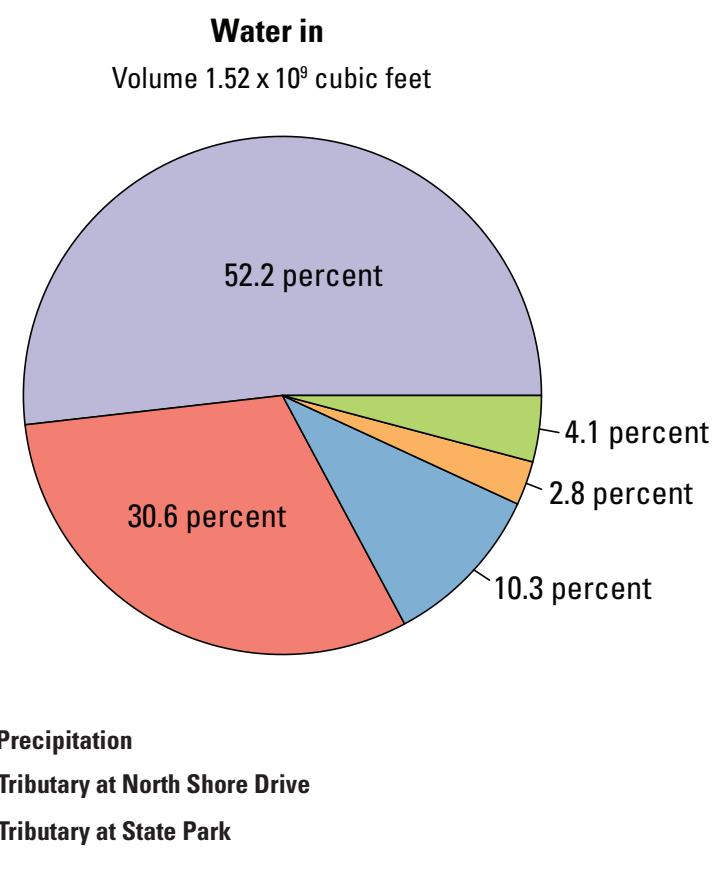

Figure 12. Annual water budget for Silver Lake, Oceana County, Michigan. 


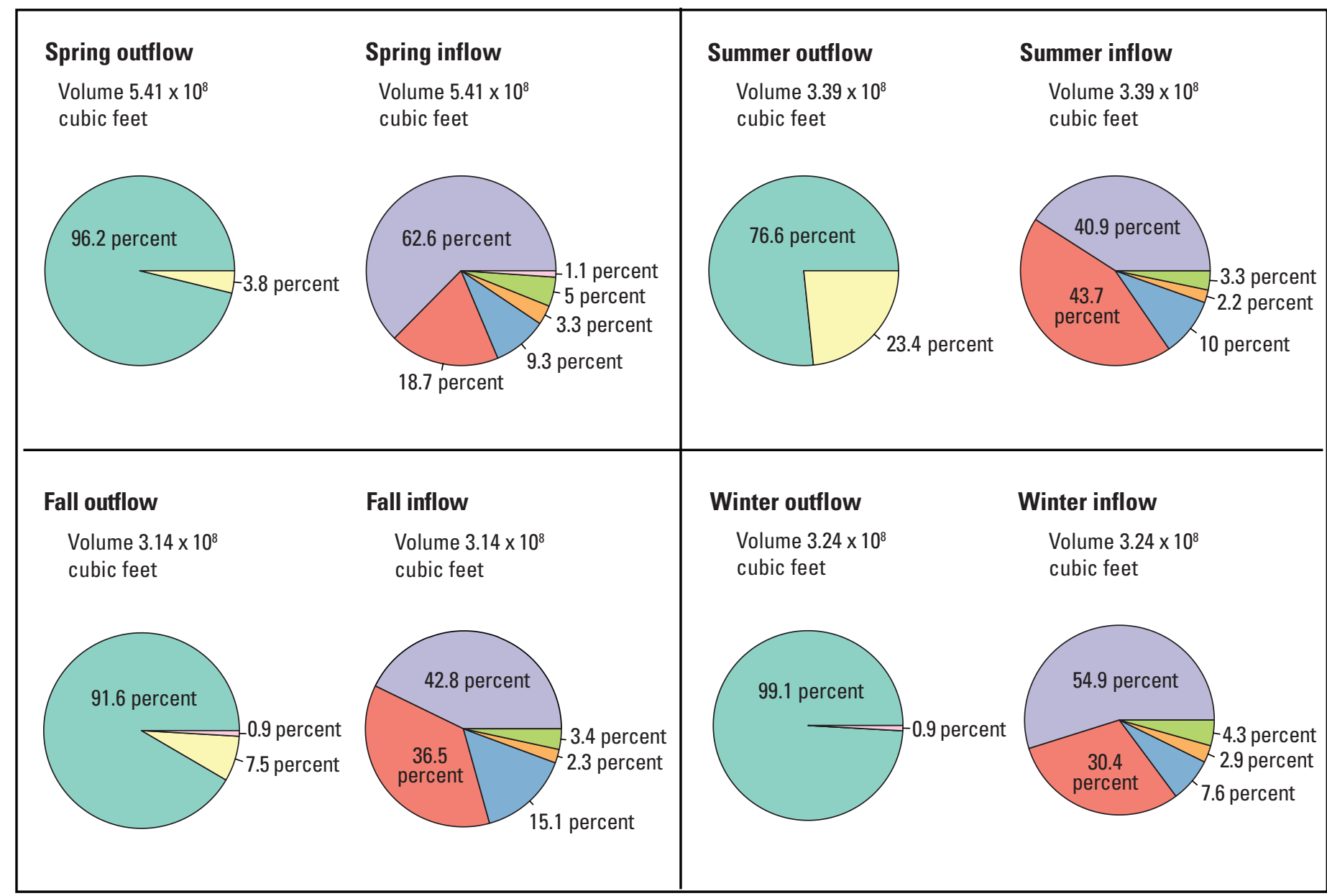

EXPLANATION

$\square$ Surface outflow
$\square \quad$ Evaporation
$\square$ Hunter Creek
$\square \quad$ Groundwater

\begin{tabular}{|l} 
Precipitation \\
Tributary at North Shore Drive \\
Tributary at State Park \\
Change in storage
\end{tabular}

Figure 13. Water budget, by season, for Silver Lake, Oceana County, Michigan.

season. During the spring season (March-May), Hunter Creek is the dominant source (62.6 percent) of water to the lake. In summer (June-August), the primary contributor of water to the lake becomes groundwater ( 43.7 percent). The fall season (September-November) shows both Hunter Creek and groundwater contributing similar proportions of the overall water budget (42.8 and 36.5 percent, respectively), with Hunter Creek being slightly more. During winter (December through February), Hunter Creek becomes the dominant source (54.9 percent) of water to the lake again. It should be noted that there is a very small change in storage for the lake by season. During the fall and winter, the lake level drops so there is a loss of water in storage of about 0.9 percent of the outflow volume in each season. In the spring there is a gain in storage of 1.1 percent of the inflow volume, which over the 2-year study balances to no net change in storage.

\section{Sources of Nutrients-Nutrient Budget}

A nutrient budget was calculated to (1) determine the sources of phosphorus and nitrogen to Silver Lake and to identify the contribution from each of these sources, and (2) calculate the nutrient output. The annual and seasonal nutrient budgets were computed using the BATHTUB model (Walker, 1996) based on 2 years of data collection. The BATHTUB model was used to simulate the current-conditions in the lake based on the data collected. The model is used to predict eutrophication-related water-quality conditions in a lake using empirical relationships that have been previously developed for lake applications (Walker, 1985). Loads estimated using the BATHTUB model are discussed in this section; details of the model data requirements, limitations, and calibration are given in the Nutrient Load Modeling section. 


\section{Nutrient Concentrations}

Nutrient data collected from Hunter Creek, the tributary at the State Park, and the tributary at North Shore Drive were analyzed and compared to the EPA ambient water-quality criteria recommendations (EPA nutrient criteria) for rivers and streams for Ecoregion VII (table 5). The seasonal nutrient loading during the winter months was not modeled due to minimal data collection during the winter season.

\section{Surface-Water Inflow and Outflow}

Hunter Creek is the largest tributary entering Silver Lake and contributes the highest inputs of nutrients compared to the other surface water inflows to the lake. Average total phosphorus concentrations fell below the EPA nutrient criteria recommendation of $0.033 \mathrm{mg} / \mathrm{L}$ (tables 5 and 6). The highest total phosphorus concentrations were typically measured during storm events (except for the April 15, 2013 event) and total phosphorus concentrations peaked during late summer and early fall months with lower concentrations recorded during the April sampling events in 2013 and 2014. Orthophosphate concentrations for Hunter Creek were typically at or below the NWQL detection limit of $0.004 \mathrm{mg} / \mathrm{L}$ and, therefore, orthophosphate is a minimal component of the phosphorus contribution from Hunter Creek. The average total nitrogen concentrations in Hunter Creek exceeded the EPA nutrient criterion recommendation of $0.54 \mathrm{mg} / \mathrm{L}$ (table 6). The highest total nitrogen concentrations were measured during the spring storm events in 2013-14, with the lowest concentrations measured in mid to late summer. Nitrate typically accounted for half of the total nitrogen in Hunter Creek, averaging $0.63 \mathrm{mg} / \mathrm{L}$ during the study.

The tributaries at the State Park and at North Shore Drive also were monitored to assess the remaining surface water inputs to Silver Lake. The average total phosphorus and total nitrogen concentrations are presented in table 6. Total phosphorus concentrations were below or slightly above the EPA nutrient criteria for both small tributaries (tables 5 and 6). There was no correlation between total phosphorus and storm events at the tributary at the State Park; however, it appears there is a seasonal distribution where total phosphorus concentrations are lowest in late winter/ early spring and increase through the summer and peak in late summer/early fall. Almost all samples collected at the tributary at North Shore Drive were collected during storm event conditions due to the low flows and minimal input during base-flow periods. Orthophosphate concentrations for both small tributaries were at or below the minimum detection limit of $0.004 \mathrm{mg} / \mathrm{L}$.

The average total nitrogen concentrations were consistent for both tributaries (table 6). At both sites, total nitrogen concentrations exceeded the EPA nutrient criterion of $0.54 \mathrm{mg} / \mathrm{L}$ (table 5 , table 6). Nitrate and organic nitrogen made up the bulk of the total nitrogen at both tributaries. At the tributary at the State Park, nitrate accounted for 71 percent of total nitrogen, and organic nitrogen accounted for about 28 percent. At the tributary at North Shore Drive, nitrate made up approximately 27 percent of total nitrogen, while organic nitrogen accounted for 69 percent.

\section{Hunter Creek upstream from the Upper}

Silver Lake outlet and the Upper Silver Lake outlet at West Taylor Road (fig. 2, table 2) were monitored on three occasions in August and September 2014; twice during storm events and once during base-flow conditions. Nutrient loads at these two sites represent approximately 1 month (29 days) of the year and were calculated from the date the first sample was collected until the last sample was collected. Upstream Hunter Creek total phosphorus concentrations ranged from 0.02 to $0.07 \mathrm{mg} / \mathrm{L}$, with an average concentration of $0.04 \mathrm{mg} / \mathrm{L}$. The Upper Silver Lake outlet total phosphorus concentrations ranged from 0.02 to $0.03 \mathrm{mg} / \mathrm{L}$, with an average concentration of $0.02 \mathrm{mg} / \mathrm{L}$. Total phosphorus concentrations either slightly exceeded or fell below the EPA nutrient criterion recommendation of $0.033 \mathrm{mg} / \mathrm{L}$ (table 5). Total nitrogen concentrations at the upstream Hunter Creek tributary ranged from 1.08 to $1.45 \mathrm{mg} / \mathrm{L}$ and averaged $1.22 \mathrm{mg} / \mathrm{L}$, and total nitrogen concentrations at Upper Silver lake outlet ranged from 0.67 to $0.77 \mathrm{mg} / \mathrm{L}$ and averaged $0.72 \mathrm{mg} / \mathrm{L}$. Both sites exceeded the EPA nutrient criterion for total nitrogen (table 5). From August 19, 2014 through September 17, 2014, approximately $53 \mathrm{lb}$ of phosphorus and 1,331 lb of nitrogen were delivered from Upper Hunter Creek and approximately $13 \mathrm{lb}$ of phosphorus and $439 \mathrm{lb}$ of nitrogen from the Upper Silver Lake outlet.

Additional monitoring and discharge measurements will be necessary to determine the annual nutrient loading from Upper Silver Lake and upstream Hunter Creek and to determine if nutrient contributions vary seasonally from each of these tributaries. Some potential sources contributing to elevated nitrogen concentrations in these tributaries include agricultural fertilizers and manure, illicit wastewater discharge, septic system input (including septic systems further than $200 \mathrm{ft}$ from Hunter Creek), precipitation and dry atmospheric deposition, and natural organic decomposition. E. coli concentrations at upper Hunter Creek exceeded the recreational criteria during two of the three sampling events (340, 1,700, and $140 \mathrm{MPN} / 100 \mathrm{~mL}$ ). Upper Silver Lake outlet E. coli concentrations exceeded the recreational criteria once (58, 440, and $6 \mathrm{MPN} / 100 \mathrm{~mL})$. 
The Silver Lake outlet (Silver Creek) also was monitored to determine the nutrient concentrations leaving Silver Lake. Those data are presented in table 6.

\section{Precipitation and Dry Deposition}

Phosphorus and nitrogen were measured in dry deposition and wet deposition on four occasions from February 2014 to September 2014, and the average concentrations are presented in table 6 . Concentrations of nutrients in wet and dry deposition displayed seasonal variability with the highest concentrations of nitrogen being observed in wet deposition in the winter, while the highest concentrations of phosphorus were observed in dry deposition in the summer. Total nitrogen concentrations were always higher in wet deposition when compared to dry deposition, while total phosphorus concentrations were higher in wet deposition in winter and fall, but higher in dry deposition in spring and summer. Spring and summer peaks in phosphorus are typically related to increased pollen deposition that occurs during these seasons (Lewis and others, 1985).

\section{Groundwater Influence}

Nutrient loading from groundwater to Silver Lake was monitored as described in the Water Quality Data CollectionGroundwater Monitoring and Flow section of this report. The influence of groundwater on Silver Lake was unknown prior to this study as previous studies never accounted for that component in the nutrient and water budgets.

To accurately determine the nutrient loading from groundwater, phosphorus and nitrogen concentrations were analyzed at the four wells installed on the east, west, north, and south sides of Silver Lake. Groundwater nutrient concentrations varied amongst the four wells (table 6) and both total phosphorus and total nitrogen concentrations were consistently highest at the south well. Orthophosphate accounted for the majority of phosphorus found in groundwater with orthophosphate concentrations ranging from 83 percent (south well) to 100 percent (west well). In addition, nutrient data from a subset of five drain tiles at the north end of Silver Lake are presented in table 6. Orthophosphate concentrations accounted for approximately 81 percent of the total phosphorus concentrations in the drain tile discharge.

\section{Other Sources of Nutrients}

This study describes 2 years of water-quality monitoring in Silver Lake (including internal loading), as well as monitoring of nutrients contributed by groundwater, tributaries, and atmospheric deposition. Other potential sources of nutrients are not individually identified in this report, as the nutrient inputs from these other sources are ultimately captured in the overall water-quality monitoring design of the study. For example, the human impacts on water quality as a result of the recreational use of the sand dunes and Silver Lake were not independently measured; however, the lake and groundwater monitoring in this study accounted for these specific inputs.

\section{Nutrient Loads}

Continuous flow data and discrete water-quality data were used to estimate nutrient loads of total phosphorus and total nitrogen from Hunter Creek using the BATHTUB model (Walker, 1996). The BATHTUB model also was used to calculate a nutrient budget for Silver Lake using water-quality data from this study.

\section{Surface-Water Inflow and Outflow}

Based on 2 years of monitoring, the mean annual load of phosphorus from Hunter Creek was $384.5 \mathrm{lb}$, and the mean annual load of nitrogen was 29,277 lb. Of the estimated loads from Hunter Creek, the septic loading model (septic systems as sources of nutrients) indicated that septic systems likely contributed 22.3 percent of phosphorus $(85.9 \mathrm{lb})$ and 0.95 percent of nitrogen $(279.3 \mathrm{lb})$. The seasonal contributions of phosphorus and nitrogen from Hunter Creek are presented in figure 14. Based on the BATHTUB model output, Hunter Creek accounted for approximately 25 percent of the phosphorus load to Silver Lake in the fall $(73 \mathrm{lb}), 33$ percent in the spring (149 lb), and 20 percent in the summer $(65 \mathrm{lb})$. Hunter Creek was the largest contributing source of nitrogen during the fall (51 percent, $8,280 \mathrm{lb}$ ) and spring seasons ( 80 percent, or $27,825 \mathrm{lb}$ ), respectively. During the summer, Hunter Creek accounted for 38 percent $(7,895 \mathrm{lb})$ of the nitrogen budget to Silver Lake (fig. 14).

Discharge was measured concurrently with sample collection at the two small tributaries and the data were entered into the BATHTUB model, along with nutrient concentrations, to calculate phosphorus and nitrogen loading. Based on 2 years of monitoring, the mean annual load of phosphorus from the tributary at the State Park was $37 \mathrm{lb}$, and the mean annual load of nitrogen was $2,111 \mathrm{lb}$. The mean annual load of phosphorus from the tributary at North Shore Drive was $29.6 \mathrm{lb}$, and the mean annual load of nitrogen was $1,032 \mathrm{lb}$. The small tributaries collectively accounted for about 5 percent of the phosphorus load during the fall and 4 percent of the phosphorus load to Silver Lake during the spring and summer. The nitrogen loading from the two small tributaries collectively made up approximately 6 percent of the nitrogen budget in the fall, 7 percent in the spring, and 5 percent in the summer (fig. 14).

The total annual output of phosphorus and nitrogen leaving the lake was approximately $1,340 \mathrm{lb}$ (99.8 percent of total phosphorus load to the lake) and 30,071 $\mathrm{lb}(57.8$ percent of total nitrogen load to the lake), respectively. Even though the majority of phosphorus leaves Silver Lake, the phosphorus remains in the lake for the duration of the lake residence time (223 days), contributing to algal blooms and eutrophication. 


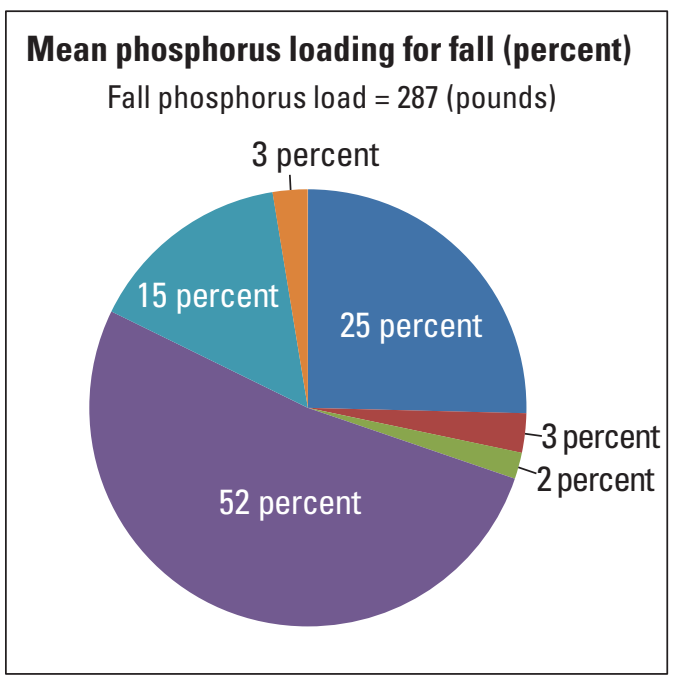

Mean phosphorus loading for spring (percent)

Spring phosphorus load $=459$ (pounds)

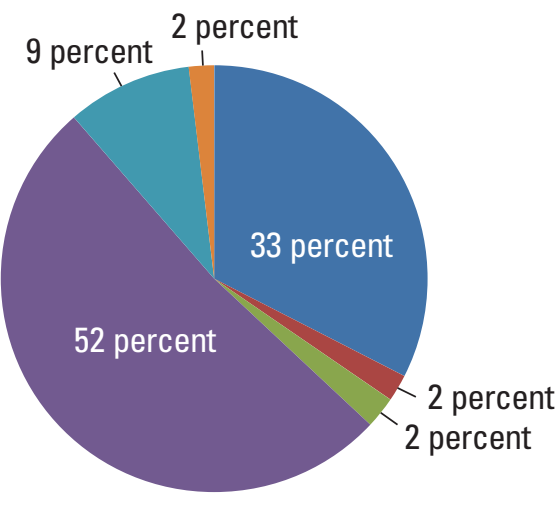

Mean phosphorus loading for summer (percent) Summer phosphorus load $=324$ (pounds)

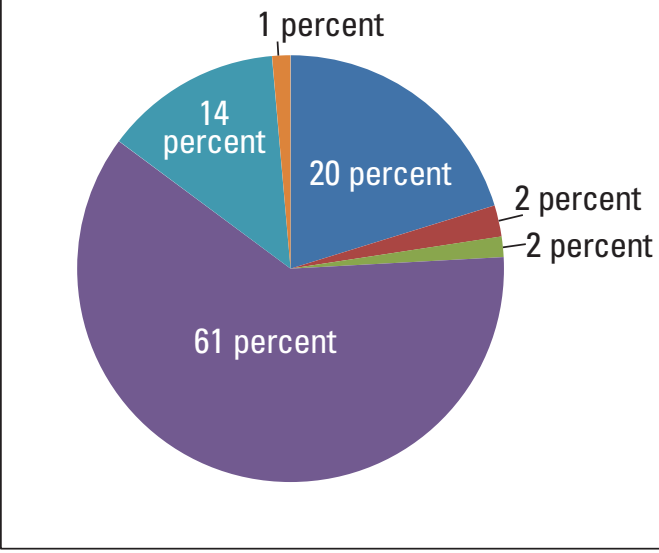

\section{Mean nitrogen loading for fall (percent)}

Fall nitrogen load $=8,921$ (pounds)

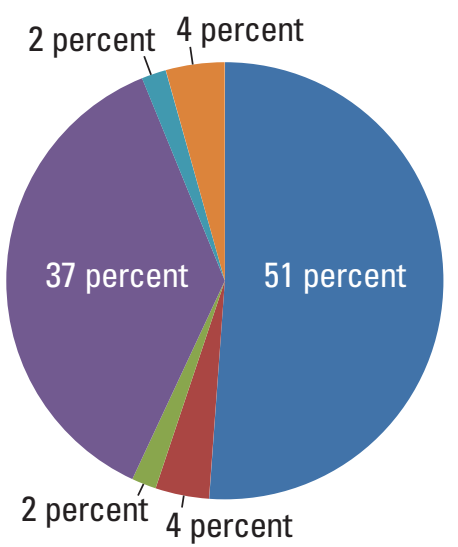

\section{Mean nitrogen loading for spring (percent)} Spring nitrogen load $=19,180$ (pounds)

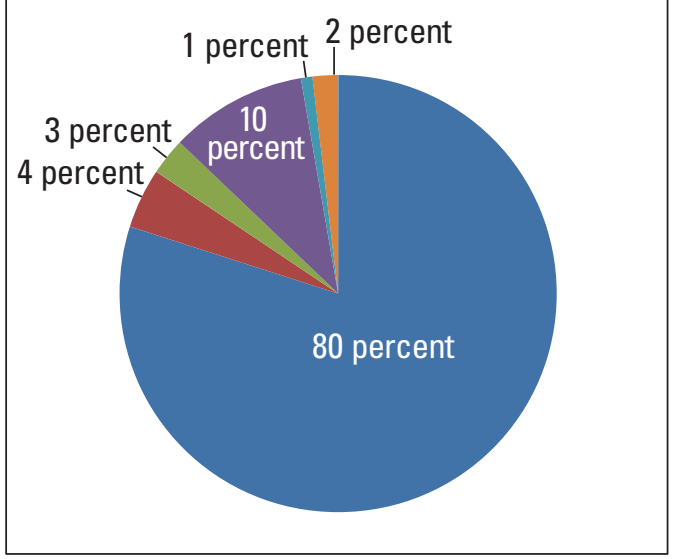

Mean nitrogen loading for summer (percent) Summer nitrogen load $=11,356$ (pounds)

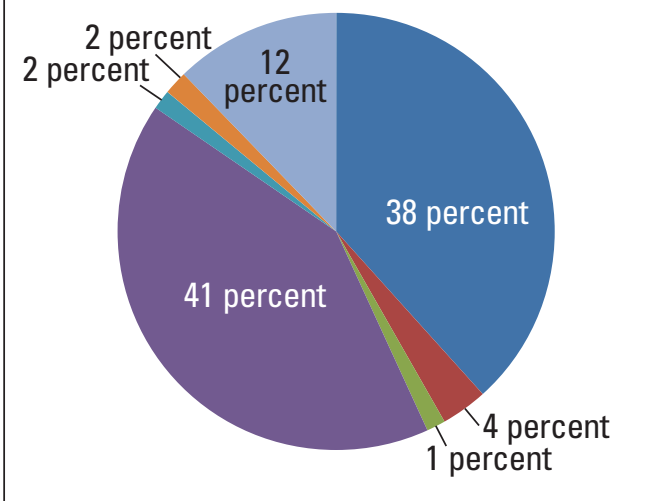

\section{EXPLANATION}

Hunter Creek

- Tributary at State Park

Tributary at North Shore Drive

Groundwater

Lawn runoff

Atmospheric deposition

Figure 14. Mean nutrient loading, by season, to Silver Lake, Oceana County, Michigan. (Internal load of phosphorus and nitrogen was measured only during the summer and assumed to be negligible during the remainder of the year. Internal phosphorus loading during the summer was less than 1 percent of the total phosphorus load.). 


\section{Precipitation and Dry Deposition}

The mean annual atmospheric load of phosphorus to Silver Lake was $87 \mathrm{lbs}$, and the mean annual load of nitrogen was 4,586 lb. The seasonal phosphorus loading from atmospheric deposition was approximately 3 percent of the phosphorus budget in the fall $(7 \mathrm{lb}), 2$ percent in the spring $(9 \mathrm{lb})$, and 1 percent in the summer $(4.5 \mathrm{lb})$. Nitrogen loading from atmospheric deposition was highest in the fall (4 percent), and made up 2 percent of the nitrogen budget during the spring and summer (fig. 14). Loads of both phosphorus and nitrogen from dry deposition were 10 to 100 times smaller than measured wet deposition loads.

The nutrient load of phosphorus and nitrogen contributed from waterfowl represents a solid mass (not a mass delivered in water) and was included in the BATHTUB model as an addition to the atmospheric deposition value. Loads attributed to waterfowl account for 0.99 percent of total phosphorus deposition and 0.11 percent of total nitrogen deposition to Silver Lake. In total, atmospheric and waterfowl loads were computed to be approximately 6 percent of the total phosphorus annual load and 9 percent of the total nitrogen annual load to Silver Lake.

\section{Groundwater Influence}

The groundwater component of the nutrient budget was calculated by dividing Silver Lake into four quadrants as described in appendix 3 . The drain tiles at the north end of Silver Lake were evaluated separately and are included in the groundwater nutrient budget. Based on 2 years of monitoring, the mean annual load of phosphorus and nitrogen from the four groundwater quadrants and the drain tiles are described in table 8 . The mean annual load of phosphorus and nitrogen from the north end drain tiles is 68 and $340 \mathrm{lb}$, respectively.

Results from the BATHTUB model showed the estimated contribution of phosphorus via groundwater to Silver Lake was highest in the summer and made up approximately 61 percent of the summer phosphorus budget $(198 \mathrm{lb})$. The phosphorus loading from groundwater accounted for approximately 52 percent of the phosphorus budget during both the fall and spring (149 and $237 \mathrm{lb}$, respectively). Study findings indicate that much of the phosphorus contribution to Silver Lake via groundwater is orthophosphate; a form of phosphorus that can readily stimulate algae growth. Based on the BATHTUB model output, groundwater accounted for 80 percent of the nitrogen budget during the spring $(1,945 \mathrm{lb}), 51$ percent during the fall $(3,290 \mathrm{lb})$, and 38 percent during the summer (4,702 lb) (fig. 14). The mean annual load from all monitored groundwater sources was $630 \mathrm{lb}$ of phosphorus and 12,951 lb of nitrogen (table 8).

The septic model (Garn and others, 1996; Reckhow and others, 1980) estimated that septic systems likely contributed 47.8 percent $(300.9 \mathrm{lb})$ of phosphorus and 1.1 percent (136.1 lb) of nitrogen to groundwater annually (fig. 15). This septic model is designed to calculate both phosphorus
Table 8. Nutrient loading from groundwater to Silver Lake, Oceana County, Michigan.

[lb/yr; pounds per year]

\begin{tabular}{lcc}
\hline \multicolumn{1}{c}{ Groundwater contribution } & $\begin{array}{c}\text { Total } \\
\text { phosphorus } \\
(\mathbf{l b} / \mathbf{y r})\end{array}$ & $\begin{array}{c}\text { Total } \\
\text { nitrogen } \\
(\mathbf{I b} / \mathbf{y r})\end{array}$ \\
\hline North quadrant & 12.4 & 39.7 \\
South quadrant & 403 & 8,811 \\
East quadrant & 14.8 & 108 \\
West quadrant & 132 & 3,653 \\
North drain tiles & 67.6 & 340 \\
Total groundwater nutrient load & $\mathbf{6 3 0}$ & $\mathbf{1 2 , 9 5 1}$ \\
\hline
\end{tabular}

and nitrogen loading, however has mostly been used for the estimation of phosphorus from septic sources as phosphorus is often times the nutrient of concern. The soil retention coefficient (SR), which represents the fraction of phosphorus or nitrogen retained between the septic system and the lake, was held constant for both phosphorus and nitrogen. The modeled septic and nonseptic (plus septic input greater than $200 \mathrm{ft}$ from shoreline) contributions to the Silver Lake nutrient budget are illustrated in figure 15 .

\section{Internal Nutrient Loading}

The results of the sediment core incubations experiments showed that internal loading is not a significant source of phosphorus in Silver Lake. Concentrations of total phosphorus in the water column overlying sediment cores tended to remain stable or slightly decline over time, and were generally less than $0.02 \mathrm{mg} / \mathrm{L}$ during the core incubations regardless of site, sampling date, or redox treatment (fig. 16). Ninety-seven to 100 percent of SRP concentrations were below the detection limit, so those data are not shown. Mean total phosphorus flux was negative and similar between redox treatments, ranging from -0.23 to -0.02 milligrams per square meter per day $\left(\mathrm{mg} / \mathrm{m}^{2} / \mathrm{d}\right)$ (table 9$)$. In lakes where internal phosphorus loading is problematic, release rates are usually much higher in anoxic than oxic conditions because a lack of dissolved oxygen leads to the reduction of ferric oxyhydroxides, thereby resulting in the dissociation of phosphorus from its bound form to iron, and a diffusion of phosphorus into the water column (Boström and others, 1982). This was not observed in the Silver Lake sediment incubations in this study, indicating that sediment release is not a significant source of phosphorus; indeed, the data indicate that sediments may actually be a minor sink for phosphorus in Silver Lake, given the negative release rates. 


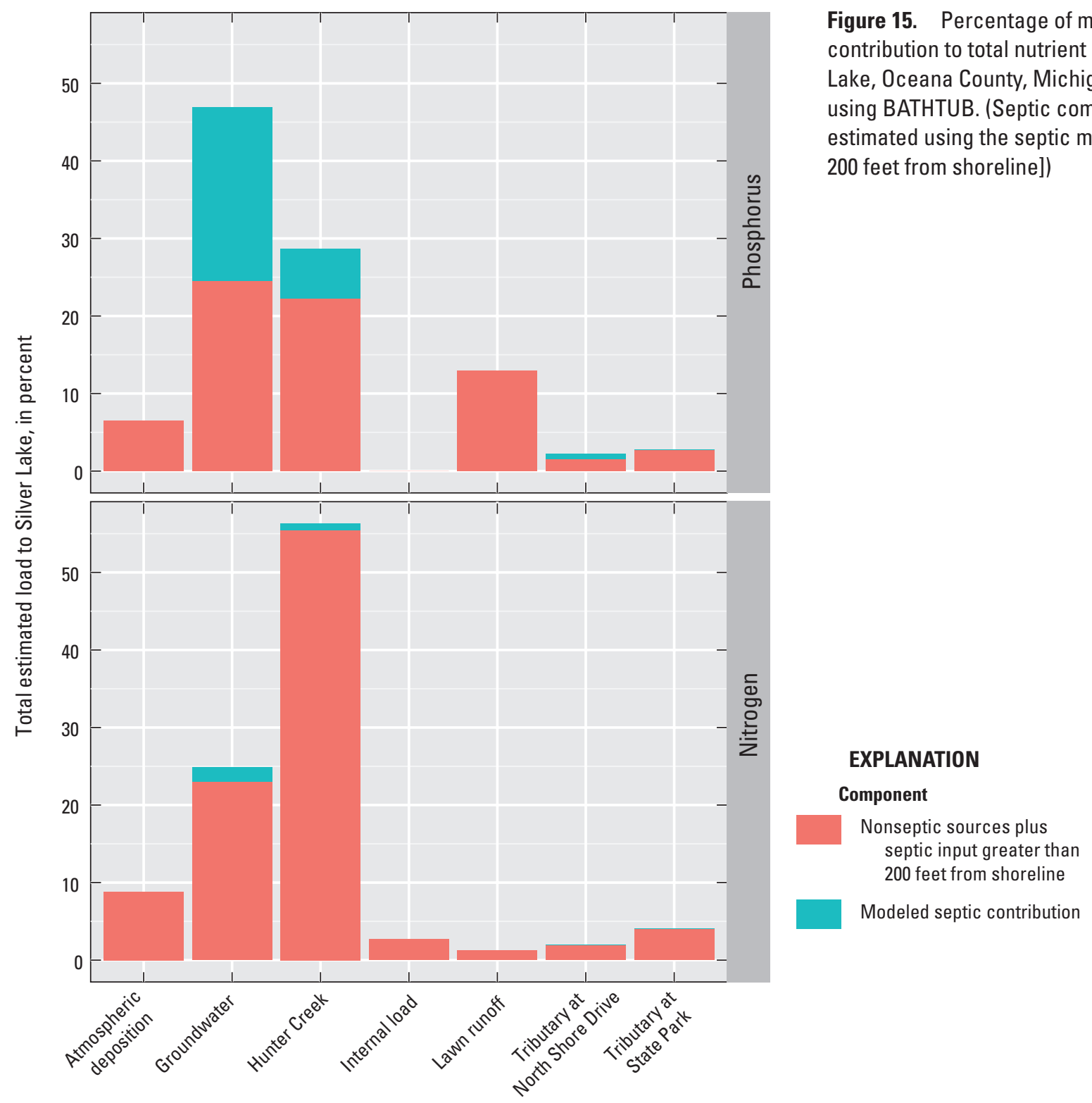

Contributing source

To place these results in a regional context, total phosphorus sediment release rates in Silver Lake were compared to that of Spring Lake, a west Michigan Lake that was experiencing significant internal phosphorus loading. This lake has undergone an alum treatment to control internal phosphorus release. In anoxic treatments, mean total phosphorus flux in Spring Lake was $18 \mathrm{mg} / \mathrm{m}^{2} / \mathrm{d}$ prior to the alum treatment, but after treatment that rate was reduced to only $0.4 \mathrm{mg} / \mathrm{m}^{2} / \mathrm{d}(1$ year after alum) and $2 \mathrm{mg} / \mathrm{m}^{2} / \mathrm{d}$ (5 years after alum) (table 9) (Steinman and others, 2004; Steinman and Ogdahl, 2008, 2012). Even in oxic treatments, when phosphorus is expected to be bound to iron, and therefore not prone to diffusion into the water column, total phosphorus flux from Spring Lake sediments was positive, albeit much lower than in anoxic treatments (table 9). Phosphorus release from sediments in Silver Lake is much lower than that in Spring Lake, irrespective of oxic or anoxic conditions.

Unlike phosphorus, the sediment core experiments revealed that internal loading is contributing nitrogen to the water column of Silver Lake. There was a distinct difference in ammonium concentrations between the redox treatments throughout the core incubation period. Initial ammonium concentrations were approximately $0.1 \mathrm{mg} / \mathrm{L}$ and increased to as much as $1.5 \mathrm{mg} / \mathrm{L}$ in anoxic treatments by day 28 (fig. 17, illustrates data from middle site only, L2). 


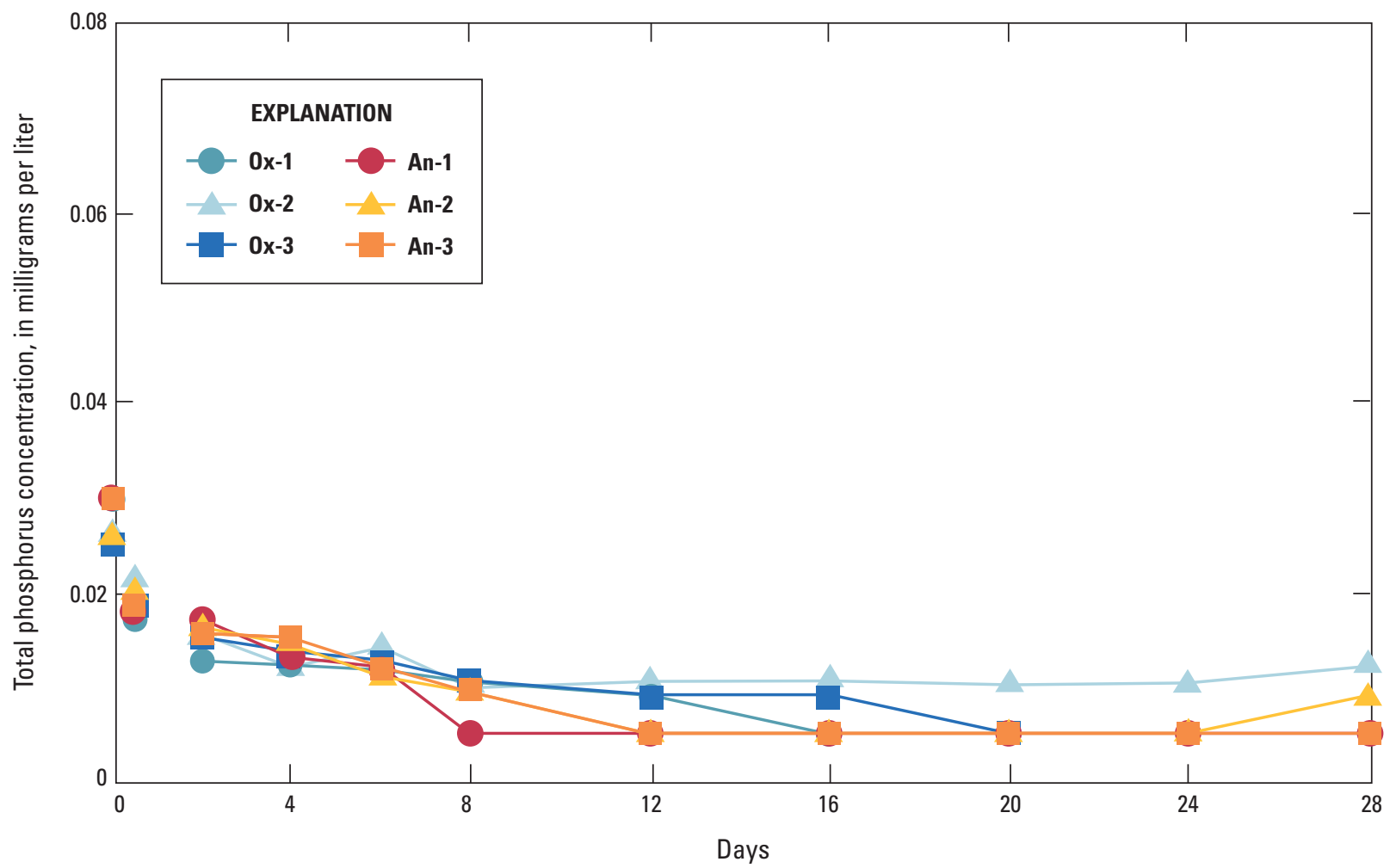

Figure 16. Total phosphorus concentrations released/retained from sediment into the water column for oxic $(0 \mathrm{x})$ and anoxic (An) treatments. (These data are from the middle site [L2], August 2014, and phosphorus release/retention patterns are representative of all release experiments.)

Table 9. Mean and standard deviation (SD) of total phosphorus (TP) and ammonium $\left(\mathrm{NH}_{4}^{+}\right)$flux, in milligrams per squaremeter per day, from sediment cores collected from Silver Lake, Oceana County, Michigan, and incubated for 28 days.

[Total phosphorus flux measured in cores from Spring Lake, Michigan, are presented for comparison: pre-alum treatment (Steinman and others, 2004), 1 year after alum treatment (Steinman and Ogdahl, 2008), and 5 years after alum treatment (Steinman and Ogdahl, 2012); $\mathrm{mg} / \mathrm{m}^{2} / \mathrm{d}$, milligrams per square meter per day; SD, standard deviation; - , no data]

\begin{tabular}{|c|c|c|c|c|c|c|c|c|c|}
\hline & & \multicolumn{4}{|c|}{ Total phosphorus flux (mg/m²/d) } & \multicolumn{4}{|c|}{ Ammonium flux (mg/m²/d) } \\
\hline & & \multicolumn{2}{|c|}{ Oxic } & \multicolumn{2}{|c|}{ Anoxic } & \multicolumn{2}{|c|}{ Oxic } & \multicolumn{2}{|c|}{ Anoxic } \\
\hline & & Mean & SD & Mean & SD & Mean & SD & Mean & SD \\
\hline \multirow{2}{*}{ Silver Lake } & August 2013 & -0.08 & 0.03 & -0.09 & 0.00 & 4.33 & 5.04 & 9.01 & 2.72 \\
\hline & June 2014 & -0.11 & 0.07 & -0.02 & 0.07 & 4.53 & 5.79 & 8.91 & 2.08 \\
\hline Silver Lake (before alum) & June/July 2003 & 0.03 & 0.44 & 17.97 & 8.07 & - & - & - & - \\
\hline Silver Lake (1 year after alum) & July 2006 & 0.20 & 0.08 & 0.41 & 0.38 & - & - & - & - \\
\hline Silver Lake (5 years after alum) & September 2010 & 1.14 & 1.24 & 2.27 & 0.46 & - & - & - & - \\
\hline
\end{tabular}




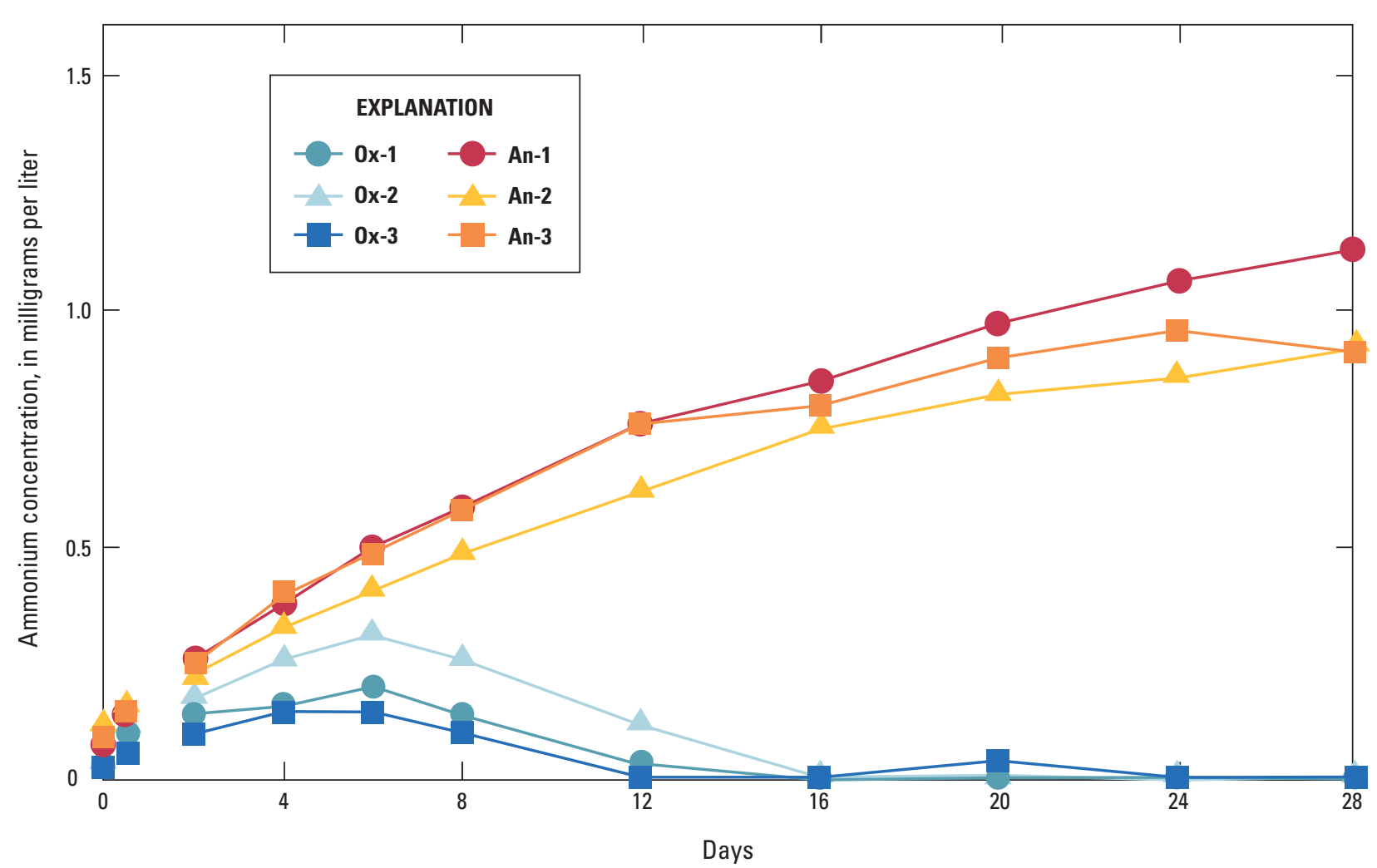

Figure 17. Ammonium concentrations released/retained from sediment into the water column for oxic (Ox) and anoxic (An) treatments. (These data are from the middle site [L2], August 2014, and release/retention patterns are representative of all release experiments.)

Ammonium concentrations in oxic treatments tended to have a slight increase for 8-12 days before decreasing to below the detection limit (fig. 17). Mean ammonium flux ranged from -1.1 to $4.5 \mathrm{mg} / \mathrm{m}^{2} / \mathrm{d}$ in oxic treatments and 4.5 to $9.9 \mathrm{mg} / \mathrm{m}^{2} / \mathrm{d}$ in anoxic treatments (table 9). There was no clear relation between ammonium flux and site or sampling date. Given that anoxic conditions appear to be rare in Silver Lake, the lower release rates in the oxic treatments are probably more representative of what is occurring in the lake than the rates under anoxic conditions. Nonetheless, if the mean oxic ammonium release rate of $2.54 \mathrm{mg} / \mathrm{m}^{2} / \mathrm{d}$ is representative of the entire lake, and it is assumed this rate is constant but occurs only during summer months, the overall mass of ammonium potentially released from Silver Lake sediments is $622 \mathrm{~kg}\left(2,719,488 \mathrm{~m}^{2}[672 \mathrm{acres}] \times 2.54 \mathrm{mg} / \mathrm{m}^{2} / \mathrm{d} \times 90 \mathrm{~d}\right)$ or approximately $1,371 \mathrm{lb}$, or about 2.6 percent of the estimated annual nitrogen mass in Silver Lake (see Nutrient Budget section). Based on the BATHTUB model simulations, the internal loading of nitrogen to Silver Lake makes up 12 percent of the nitrogen load during the summer months (fig. 14). Internal loading of nitrogen from sediments is a modest source in Silver Lake; however, these rates may be overestimates given that they are gross inputs and do not account for potential nitrogen losses such as denitrification.
Sediment total phosphorus concentrations (upper $5 \mathrm{~cm}$ ) were less than 1,000 milligrams per kilogram $(\mathrm{mg} / \mathrm{kg})$ at both sites during all coring events, and less than $500 \mathrm{mg} / \mathrm{kg}$ at the middle site with the exception of August 2014 (fig. 18). Compared to other west Michigan lakes, sediment total phosphorus concentrations in Silver Lake are low, particularly at the middle site (fig. 18).

The concentrations of four key sediment metals (calcium, iron, phosphorus, and aluminum) were higher at the south site than at the middle site. Calcium was the most abundant element, followed by iron. Iron:total phosphorus ratios (by weight) were 23 and 12 at the south and middle sites, respectively. Lakes with iron:total phosphorus ratios greater than 15 tend to have low SRP flux under oxic conditions (Jensen and others, 1992), such as those observed in Silver Lake. This is because the ferric oxyhydroxides bind to phosphorus, preventing its diffusion into the water column above (Boström and others, 1982). In general, it appears there is sufficient iron to bind the phosphorus that is present in Silver Lake sediments, and prevent diffusion under oxic conditions. However, the iron:total phosphorus ratio should be applied with care because the ratio uses total phosphorus, which includes forms that may not be available for biotic uptake (Rydin and others, 2000). Phosphorus fractionation would be necessary to determine how much of the total phosphorus is in the bioavailable phosphorus fraction in these sediments. 


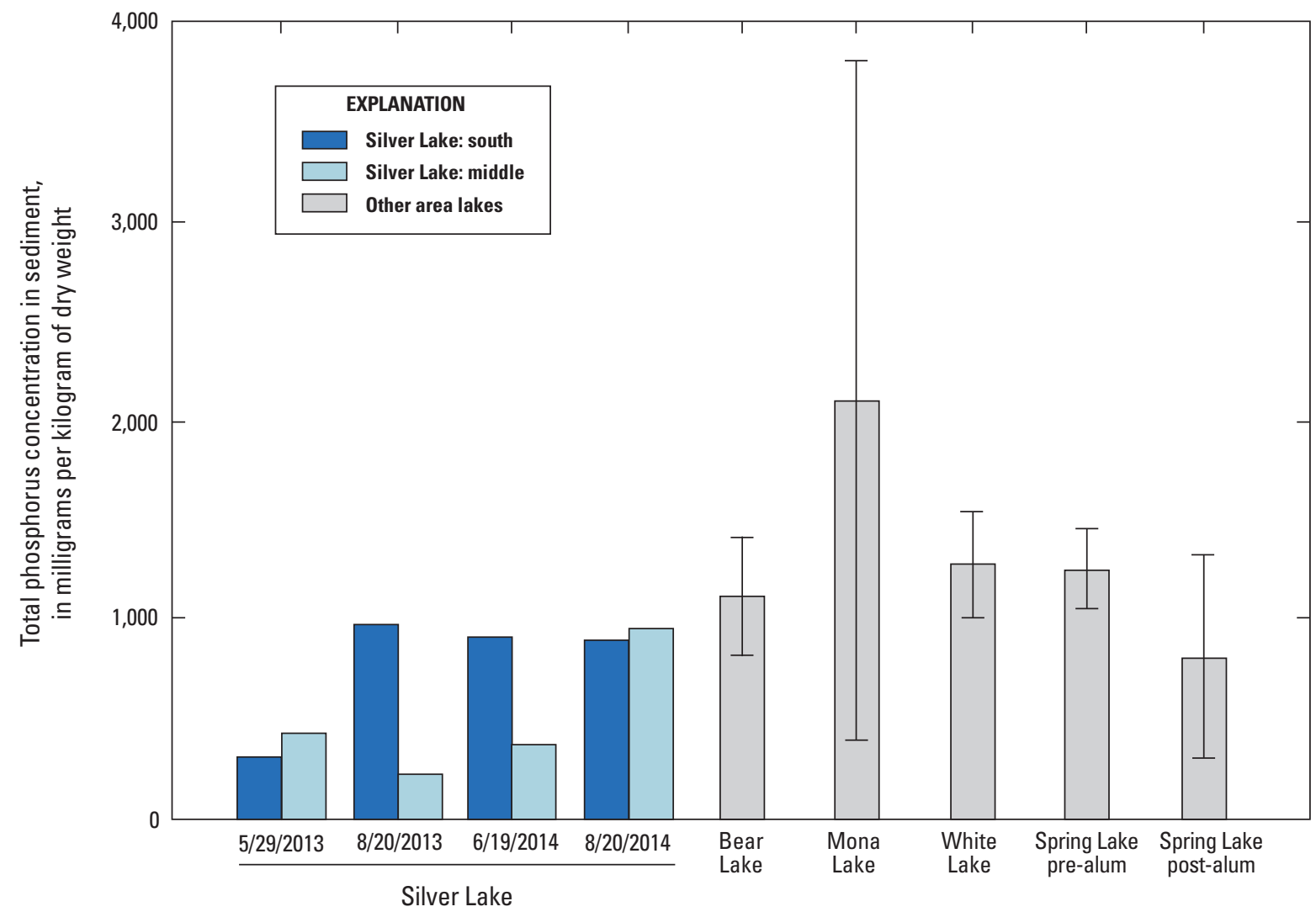

Figure 18. Total phosphorus concentrations in sediment (upper 5 centimeters) at the two internal loading study locations in Silver Lake, Oceana County, Michigan, on each core collection date. (Mean [plus or minus standard error] total phosphorus in sediment for other lakes in west Michigan are provided for comparison [gray bars]. Sources: Bear Lake, Steinman and Ogdahl, 2015; Mona Lake, Steinman and others, 2009; White Lake, Steinman and others, 2008; Spring Lake before alum treatment, Steinman and others, 2004; Spring Lake after alum treatment, Steinman and Ogdahl, 2008)

\section{Lawn Runoff}

Based on the BATHTUB model output, the contribution of phosphorus via lawn runoff to Silver Lake was highest in the summer and fall and made up approximately 14 and 15 percent of the summer and fall phosphorus budgets, respectively (estimated $44 \mathrm{lb}$ per season) (fig. 14). The phosphorus loading from lawn runoff accounted for approximately 9 percent of the phosphorus budget during the spring even though the lawn-runoff estimates considered the predominant use of phosphate-free fertilizer. Lawn runoff accounted for a small component of the nitrogen budget during the spring, summer, and fall (1 percent during the spring, and 2 percent during the summer and fall) (163 lb per season) (fig. 14). Overall, lawn runoff accounted for approximately 13 percent of the annual phosphorus budget and 1 percent of the annual nitrogen budget (fig. 19).

\section{Nutrient Budget Summary}

The nutrient budget for Silver Lake was calculated using the BATHTUB model based on 2 years of water quality data collection. A mean annual phosphorus and nitrogen budget summary were calculated for Silver Lake and are presented in figure 19. A seasonal breakdown on the phosphorus and nitrogen budgets was also summarized and is presented in figure 14 .

The mean annual input of phosphorus to Silver Lake was approximately 1,342 lb. The major sources of phosphorus to Silver Lake were groundwater (630 lb, or 46.9 percent) followed by Hunter Creek (385 lb, or 28.7 percent) (fig. 19). A large proportion of the phosphorus load being delivered to the lake by groundwater and Hunter Creek is likely originating from septic systems. Septic model loading scenarios indicate that 19.5 to 73.7 percent of phosphorus in groundwater and 2.1 to 43.6 percent of phosphorus in Hunter Creek is likely derived from septic loading. The most likely septic loading scenario estimates that septic systems contribute 47.8 percent of the phosphorus to groundwater and 22.3 percent of phosphorus to Hunter Creek (table 10). These results indicate that septic systems are a major source of phosphorus loading to Silver Lake. The 


\section{Average annual phosphorus loading}

(in percent)

Annual phosphorus load=1,342 pounds

\section{Average annual nitrogen loading \\ (in percent)}

Annual nitrogen load=51,998 pounds
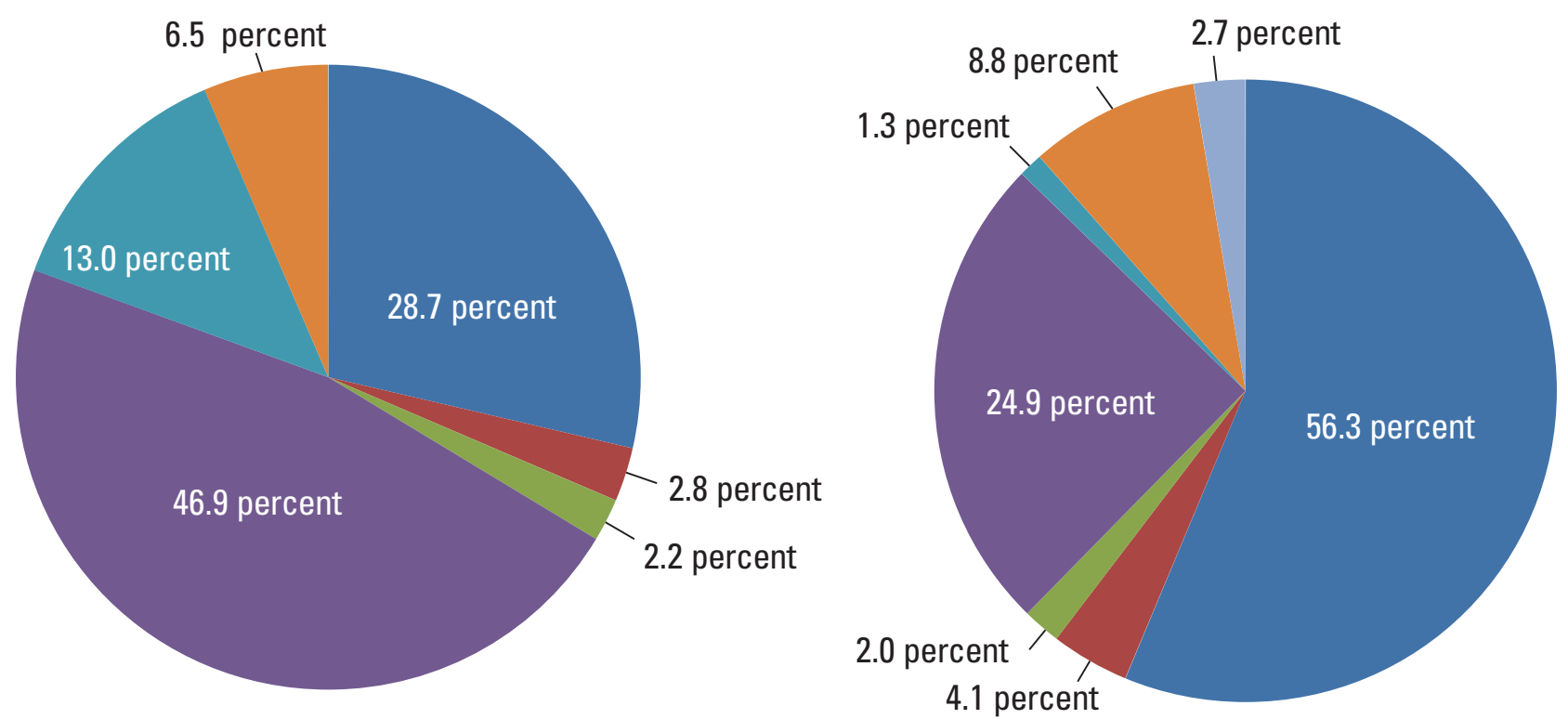

\section{EXPLANATION}

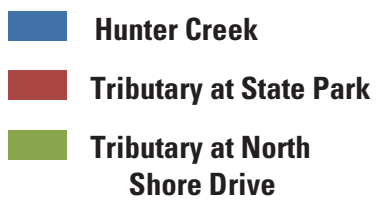

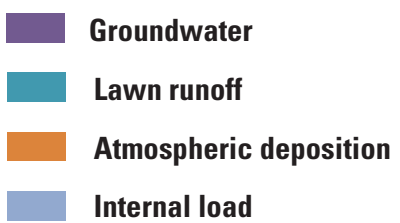

Internal load

Figure 19. Annual phosphorus and nitrogen budget summaries for Silver Lake, Oceana County, Michigan. (Internal load of phosphorus and nitrogen was measured only during the summer and assumed to be negligible during the remainder of the year. Internal phosphorus loading during the summer was less than 1 percent of the total phosphorous load.)

largest loading of phosphorus to Silver Lake occurred in the spring months, followed by the summer and fall (fig. 14). Of the total $1,342 \mathrm{lb}$ of phosphorus that entered Silver Lake annually (mean), almost all of the phosphorus was exported out of the lake $(1,340 \mathrm{lb})$, with minimal to no phosphorus deposition occurring in the lake-bed sediment, which is consistent with the estimated analysis of internal phosphorus loading from the sediment cores. Although the majority of phosphorus is exported out of the lake with minimal internal loading, the residence time (223 days) is long enough for phosphorus to contribute to algal blooms and lake eutrophication in Silver Lake.

The mean annual input of nitrogen to Silver Lake was approximately $51,998 \mathrm{lb}$. The major source of nitrogen to Silver Lake was Hunter Creek $(29,277$ lb, or 56.3 percent of the nitrogen budget). Other major sources of nitrogen to Silver Lake include groundwater $(12,951 \mathrm{lb}$, or 24.9 percent of the nitrogen budget) and atmospheric deposition $(4,586 \mathrm{lb}$ or 8.8 percent) (fig. 19). The septic model loading scenarios indicate that septic systems account for 0.05 to 3.1 percent of the load to Hunter Creek, and 0.23 to 2.8 percent of the contribution of nitrogen to groundwater (table 10). The most likely septic loading scenario indicates that septic systems account for 0.95 percent of the nitrogen load to Hunter Creek and 1.1 percent of the contribution of nitrogen to groundwater. Other potential sources of nitrogen to groundwater include animal manure and nitrogen fertilizers used for agriculture, animal pasture, food processing discharge, leaching from fertilizers from private lawns and golf courses, and the ongoing decay of organic matter in the soil (Oregon Department of Environmental Quality, 2011). The largest nitrogen loading to Silver Lake also was observed during the spring, followed by the summer and fall months. About twice as much nitrogen entered Silver Lake during the spring $(19,180 \mathrm{lb})$ compared to the fall months $(8,921 \mathrm{lb})$ (fig. 14). Of the $51,998 \mathrm{lb}$ of nitrogen that entered Silver Lake annually (mean), approximately 42.2 percent (or 21,928 lb) of nitrogen was deposited in the lake bed sediment as simulated by the BATHTUB model. 
Table 10. Summary of septic-load estimates to Silver Lake, Oceana County, Michigan, using the septic model.

[lb/yr; pounds per year]

\begin{tabular}{lcccc}
\hline \multicolumn{1}{c}{$\begin{array}{c}\text { Septic load } \\
\text { scenario }\end{array}$} & $\begin{array}{c}\text { Phosphorus load } \\
\text { from septic } \\
\text { (Ib/yr) }\end{array}$ & $\begin{array}{c}\text { Septic percentage of } \\
\text { average annual Load } \\
\text { (percent) }\end{array}$ & $\begin{array}{c}\text { Septic contribution } \\
\text { to groundwater } \\
\text { (percent) }\end{array}$ & $\begin{array}{c}\text { Septic contribution } \\
\text { to Hunter Creek } \\
\text { (percent) }\end{array}$ \\
\hline Most likely & 396 & 29.5 & 47.8 & 22.3 \\
Low & 132 & 9.8 & 19.5 & 2.1 \\
High & 650 & 48.4 & 73.7 & 43.6 \\
\hline \multicolumn{1}{c}{ Septic load } & $\begin{array}{c}\text { Nitrogen load } \\
\text { from septic } \\
\text { (Ib/yr) }\end{array}$ & $\begin{array}{c}\text { Septic percentage of } \\
\text { average annual Load } \\
\text { (percent) }\end{array}$ & $\begin{array}{c}\text { Septic contribution } \\
\text { to groundwater } \\
\text { (percent) }\end{array}$ & $\begin{array}{c}\text { Septic contribution } \\
\text { to Hunter Creek } \\
\text { (percent) }\end{array}$ \\
\hline Most likely & 445 & 0.86 & 1.1 & 0.95 \\
Low & 46 & 0.09 & 0.23 & 0.05 \\
High & 1,362 & 2.62 & 2.8 & 3.10 \\
\hline
\end{tabular}

\section{Nutrient Load Modeling}

Nutrient concentration data and flow data collected from all major potential nutrient pathways were used to estimate the trophic status of Silver Lake. The BATHTUB model (Walker, 1996) was used to simulate the current conditions in the lake based on the data collected. In addition, the BATHTUB model was used to estimate the effect on the trophic status of Silver Lake as a result of changes to various nutrient inputs to the lake.

\section{BATHTUB Data Requirements and Limitations}

Multiple datasets were compiled and evaluated to determine the appropriate input data for the BATHTUB model: (1) an annual dataset consisting of data collected October 1, 2013September 30, 2014 (water year 2014), (2) a complete dataset consisting of all data collected throughout the study period ( 2 years), and (3) a categorization of seasonal and specified storm events. For this dataset, the nutrient turnover ratio (Nutrient Turnover Ratio = Length of Averaging Period for Mass Balances [years] / Mass Residence Time [years]), which approximates the number of times that the nutrient mass in the lake is displaced during the averaging period, was approximately or greater than 2.0 (turnover ratio for phosphorus and nitrogen, 1.6 and 2.8, respectively) as recommended in the model (Walker, 1996), and therefore was chosen as the final dataset for the model. Note that the seasonal datasets (spring, summer, and fall) were evaluated and used in the calculation of seasonal nutrient loading as described in the Nutrient Budget Summary section.
Even though the loading data are summarized for the entire study, the BATHTUB model predicts the effects of nutrient loading on an annual basis. The idea of partitioning out the storm event datasets in an effort to evaluate these events separately from the annual loading proved to be difficult. The storm event datasets were limited and because of insufficient data from which to accurately describe the different input sources without excessive model calibration, which fell outside the recommended calibration criteria (Walker, 1996). Thus, storm events were not examined separately but were evaluated as a whole with the rest of the nutrient dataset.

The BATHTUB model required specified input data including Silver Lake morphometric data, hydrologic data, and nutrient concentration data for each source. Silver Lake was treated as one segment, and observed nutrient concentrations and flow data were entered in the model based on an annual mean using 2 years of data for each of the tributaries, the outlet, the four groundwater quadrants, and the tile drains. The atmospheric deposition component of the BATHTUB model was based on approximately 1 year of data collection. The internal nutrient loading was calculated based on two sampling events. The model input for lawn runoff was calculated (as described in Study Methods and Sampling Sites, Lawn Runoff section of this report), and identified in the model as a point source. 


\section{Algorithms and Calibration}

Prior to running the BATHTUB model, the model algorithms must be defined. The model algorithms selected for this study were based on site characteristics, available data, and for diagnostic and predictive purposes. The model algorithms are described in table 11.

Calibration factors provide means for adjusting model predictions to account for site-specific conditions in order to match observed conditions. The need for site-specific calibration is indicated when significant differences between observed and predicted concentrations are found during initial model runs (Walker, 1996). The nutrient model algorithms chosen for this study (table 11) have been empirically calibrated and tested for predicting lake-mean conditions (Walker, 1996). The BATHTUB error analysis calculations indicate that sedimentation rates predicted by these models are generally accurate to within a factor of 2 for phosphorus and a factor of 3 for nitrogen (Walker, 1996). To account for this error, nutrient calibration factors can be adjusted within the nominal ranges of 0.5 to 2.0 and 0.33 to 3 for phosphorus and nitrogen, respectively. For this study, calibration coefficients for each water-quality constituent were applied globally to the base model prior to running diagnostic and predictive scenarios. The calibration factors are, by model default, set to 1 . The model calibration factors used to adjust the predicted water-quality conditions for this study ranged from 1 to 1.7 and fell within the acceptable ranges for each water-quality constituent (total phosphorus, 1.67; total nitrogen 1.09; and chlorophyll $a, 1.23$ ).

Table 11. Model algorithms selected when running BATHTUB simulations for Silver Lake, Oceana County, Michigan.

\begin{tabular}{|c|c|c|c|}
\hline Select model & Options & Model process & Description (excerpt from Walker, 1996) \\
\hline $\begin{array}{l}\text { Conservative } \\
\text { substance }\end{array}$ & 0 & Not computed & $\begin{array}{l}\text { Conservative substance concentration is user-defined, typically chloride; } \\
\text { can be used for verification of water budgets or calibration of longitudinal } \\
\text { dispersion rates. }\end{array}$ \\
\hline Phosphorus balance & 1 & $\begin{array}{l}\text { Second order, available } \\
\text { phosphorus }\end{array}$ & $\begin{array}{l}\text { Performs mass balance calculations on available phosphorus, a weighted } \\
\text { sum of orthophosphorus and non-orthophosphorus which places a heavier } \\
\text { emphasis on the orthophosphorus (more biologically available) component. }\end{array}$ \\
\hline
\end{tabular}

$\begin{array}{ccc}\text { Chlorophyll } a & 1 \quad \begin{array}{c}\text { Function of phosphorus, } \\ \text { nitrogen, light, and }\end{array} & \begin{array}{c}\text { Eutrophication response models relate observed or predicted pool nutrient } \\ \text { levels to measures of algal density and related water quality conditions. }\end{array}\end{array}$
temperature

Secchi depth $\quad 1 \quad \begin{gathered}\text { Function of chlorophyll a Model default, secchi reported as a function of chlorophyll a and turbidity. } \\ \text { and turbidity }\end{gathered}$

Dispersion $\quad 1 \quad$ Fischer numeric

Phosphorus
calibration

\begin{tabular}{lll} 
Nitrogen calibration & 2 & Concentrations \\
\hline Error analysis & 1 & Model and data
\end{tabular}

Availability factors $\quad 1 \quad$ Use for model 1 only

Mass-balance tables observed
concentrations

For a given segment width, mean depth, and outflow, numeric dispersion is proportional to segment length. By selecting segment lengths to keep numeric dispersion rates less than the estimated values, the effects of numeric dispersion on the calculations can be approximately controlled.

The empirical models implemented in BATHTUB are generalizations about reservoir behavior. When applied to data from a particular reservoir without site-specific calibration, observations may differ from predictions by a factor of two or more. Such differences reflect data limitations (measurement or estimation errors in the average inflow and outflow concentrations), as well as unique features of the particular reservoir. A procedure to calibrate the model to match observed reservoir conditions is provided in BATHTUB.

Same as above.

The first-order error analysis procedure implemented by BATHTUB can be used to estimate the uncertainty in model predictions derived from uncertainty in model inputs and uncertainty inherent in the empirical models.

Selected as orthophosphorus and organic nitrogen values were specified; calculates nutrient balances based upon available nutrient loads.

Use observed segment concentrations to calculate outflow and storage terms. 


\section{Management Scenario Simulation Approach}

Several nutrient modification scenarios were modeled to illustrate the effect of changing input nutrient concentrations on the trophic status of Silver Lake as well as algal bloom occurrence. Only nutrient inputs that could be adjusted by employing a nutrient management practice around the lake were tested. Thus, only groundwater and surface-water pathways of nutrients to the lake were adjusted. The atmospheric pathway would likely not be affected by any management practice employed by the community around Silver Lake. Likewise, the groundwater on the west side of Silver Lake was not adjusted, because no controllable source of nutrients was identified for that side of the lake. Thirty separate scenarios were developed to assess the effects of nutrient input adjustment on the trophic status of the lake. The calibration coefficients determined for the base scenario were held constant for all the management scenarios. Results from those scenarios are provided in table 12. The results of these scenarios provide a basis to assess the amount nutrient inputs may need to change to have an effect on the trophic status of Silver Lake. Also, the nutrient input adjustments listed in table 12 were modeled to predict the number of days that Silver Lake would likely experience algal blooms. Finally, three scenarios were modeled to examine the potential effect on the trophic status of Silver Lake from converting residences around the lake from on-site septic waste disposal to a centralized sewage system.

\section{BATHTUB Model Simulations}

This section describes the BATHTUB model simulations that were processed in order to predict future lake responses as a result of nutrient reductions or increases and other sitespecific scenarios.

\section{Nutrient Loading Scenarios}

Nutrient adjustment scenarios of phosphorus and nitrogen to Silver Lake were processed using the BATHTUB model. Results of the simulations for groundwater, Hunter Creek, as well as a combination of sources are presented in table 12.

\section{Trophic Status}

The trophic status of Silver Lake is directly affected by changes in nutrient loading; thus, the predicted changes in nutrient loading and associated trophic status were examined. Carlson's TSI was calculated to identify changes in trophic status using the equations for Secchi depth, phosphorus, and chlorophyll $a$ (Carlson, 1977) (also see, Trophic Status and Lake Classification section).

The groundwater, Hunter Creek, and combination of sources (groundwater + Hunter Creek + lawn runoff) nutrient loading scenarios for phosphorus and nitrogen are presented in figure 20. Results from the baseline, or base model, are highlighted in pink and indicate the calibrated dataset. Based on Carlson's TSI, the baseline calibrated dataset indicates that
Table 12. Nutrient concentration adjustment scenarios simulated using the BATHTUB model.

\begin{tabular}{cccc}
\hline & \multicolumn{3}{c}{ Adjusted source, in percent $^{\text {Combination of }}$} \\
\cline { 2 - 4 } & Groundwater $^{1}$ & Hunter Creek & $\begin{array}{c}\text { Comoundwater', } \\
\text { ground } \\
\text { Hunter Creek, and } \\
\text { lawn runoff }\end{array}$ \\
\hline & -75 & -75 & -75 \\
\hline Phosphorus & -50 & -50 & -50 \\
\hline and nitrogen & -25 & -25 & -25 \\
concentration & 50 & 25 & 25 \\
adjustment & 75 & 50 & 50 \\
& 100 & 75 & 75 \\
& 200 & 100 & 100 \\
\hline & 300 & 200 & 200 \\
\hline & 400 & 300 & 300 \\
\hline
\end{tabular}

${ }^{1}$ Groundwater inputs were only adjusted for north, east, and south quadrants and the drain tile component in the north quadrant.

Silver Lake is eutrophic. Thus, all nutrient loading scenarios begin with the lake being eutrophic. All scenarios that involve an increase in nutrient loading result in an increase in lake eutrophication.

Changes in groundwater nutrient loading of phosphorus and nitrogen were simulated by adjusting groundwater contributions from the north, east, and south quadrants of Silver Lake as well as groundwater contribution from the drain tiles at the north end of the lake. A reduction or increase in groundwater nutrient loading from the west quadrant of Silver Lake is not likely to change from the current conditions. Thus the nutrient loading for the west quadrant of Silver Lake stayed at baseline conditions for all scenario testing. According to the BATHTUB model, if groundwater loading of phosphorus and nitrogen were decreased by 75 percent, and all of the other nutrient inputs stayed the same, the condition of Silver Lake would most likely range from highly mesotrophic to eutrophic (the current condition of Silver Lake). If nutrient loading continued to increase in groundwater, for instance as a result of aging septic fields or the introduction of more homes on the lake, the lake would continue to remain eutrophic with more frequent algal blooms.

BATHTUB model simulations of changes in nutrient loading of phosphorus and nitrogen in Hunter Creek are presented in figure 20. If nutrient loading from Hunter Creek decreased by 50 percent or 75 percent, and all of the other nutrient inputs stayed the same as the baseline dataset, Silver Lake would remain eutrophic based on TSI calculations using phosphorus and chlorophyll $a$. Only under the TSI scenario based on Secchi depth would the trophic status of the lake develop into highly mesotrophic. Therefore, the reduction of nutrients from Hunter Creek alone may not be enough to effectively improve the trophic status and related water quality issues in Silver Lake as simulated by the BATHTUB model. 
Concentration adjustment scenario
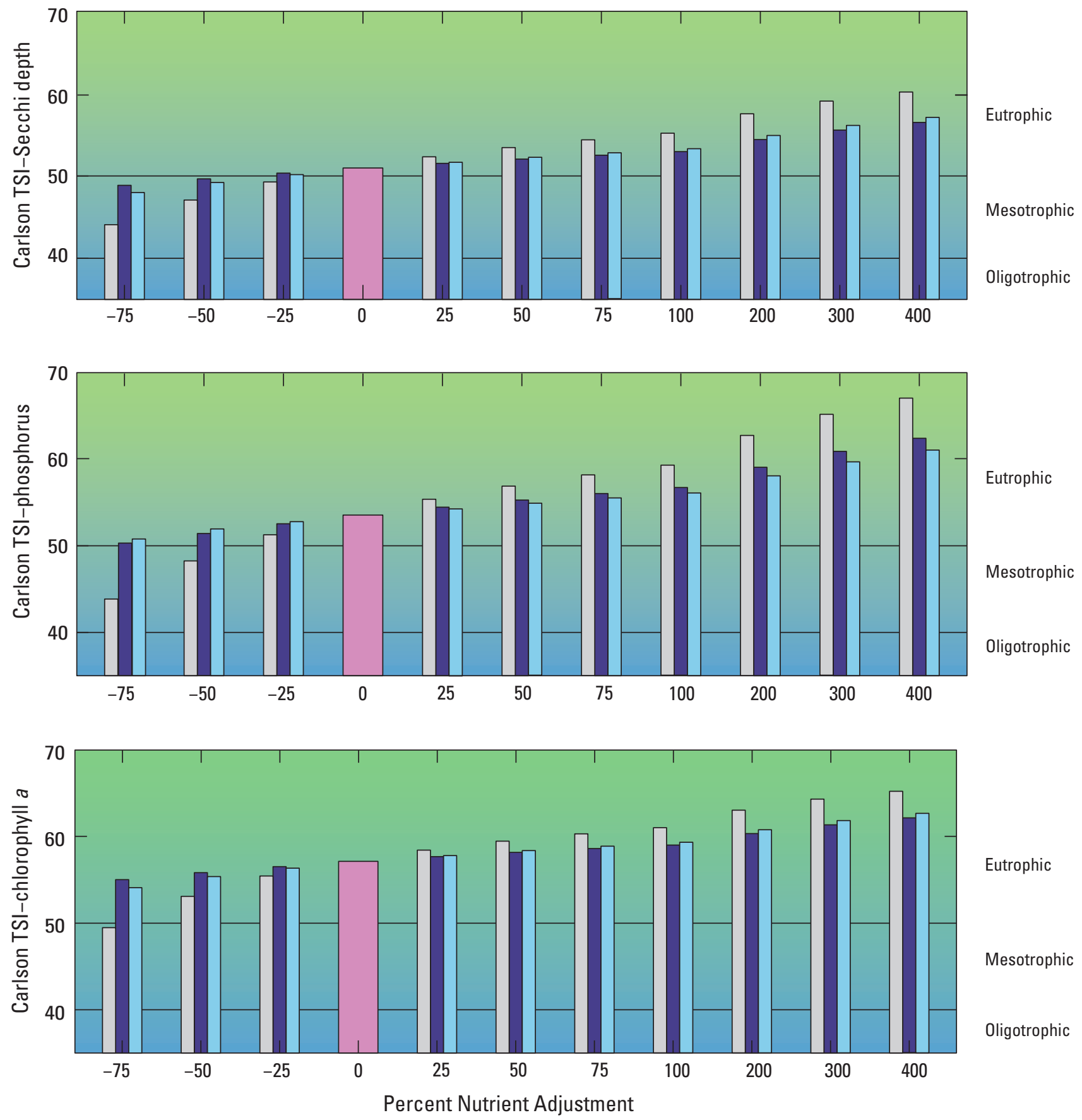

EXPLANATION

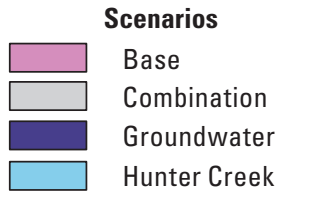

TSI Trophic state index

Figure 20. Summary of nutrient loading scenarios using the BATHTUB model for Silver Lake, Oceana County, Michigan. (Based on Carlson's Trophic State Index (TSI) values, less than 40 represents oligotrophic conditions, 40-50 mesotrophic, and greater than 50 represents eutrophic conditions.) 
By reducing the input of multiple manageable nutrient sources, the BATHTUB model indicates that there is a better likelihood of positively impacting the trophic status of Silver Lake and reducing algal bloom frequency. Multiple nutrient sources, including groundwater contribution from the north, east, and south quadrants, Hunter Creek, and lawn runoff were evaluated as these sources offer the best opportunity for future nutrient management. Both phosphorus and nitrogen scenarios were run for each of these three sources, collectively referred to in figure 20 as Combination. Increases in nutrients continue to push the lake into a higher eutrophic state; however, a reduction of nutrients indicates a move towards mesotrophy. Using the TSI equation for Secchi depth, a combination of source reduction of only 25 percent would be sufficient to classify Silver Lake as mesotrophic. A reduction of phosphorus and nitrogen by 75 percent would classify Silver Lake as mesotrophic using all three of Carlson's TSI equations which is indicative of improved water quality, water clarity, and reduced algal bloom frequency. Similarly, an annual phosphorus loading reduction from the current condition $(1,342 \mathrm{lb})$ to $549 \mathrm{lb}$ and a change in the annual nitrogen loading to $22,580 \mathrm{lb}$ would be necessary to classify Silver Lake as mesotrophic based on all three TSI equations.

\section{Changes in Percentage of Days with Algal Blooms}

Algal blooms can negatively impact the recreational use of a lake and also have an impact on lake aesthetics. Some algal blooms can also be potentially hazardous to human and pet health. Silver Lake has a history of algal bloom occurrence during the summer and fall months, and in October 2012, an algal bloom was reported in Hunter Creek. Chlorophyll $a$ is used to measure algal productivity in the water and the higher the chlorophyll concentrations, the more severe the algal bloom intensities. Carlson describes that the range of chlorophyll $a$ concentrations indicating eutrophic conditions range from 7.3 to $20 \mu \mathrm{g} / \mathrm{L}$ (Carlson, 1977), thus for this study it was determined that chlorophyll $a$ concentrations greater than $10 \mu \mathrm{g} / \mathrm{L}$ may indicate that an algal bloom is present. Simulations were run using the BATHTUB model to evaluate the number of days Silver Lake could experience algal blooms as a result of an increase and decrease in phosphorus and nitrogen loading from groundwater, Hunter Creek, as well as a combination of sources (table 13).

During the course of this study, measured chlorophyll $a$ concentrations ranged from 0.7 to $39 \mu \mathrm{g} / \mathrm{L}$ and averaged approximately $15 \mu \mathrm{g} / \mathrm{L}$. According to the BATHTUB model, Silver Lake currently experiences about 231 days of the year where chlorophyll $a$ concentrations are greater than $10 \mu \mathrm{g} / \mathrm{L}$ and about 80 days of the year where chlorophyll $a$ concentrations are greater than $20 \mu \mathrm{g} / \mathrm{L}$ (conditions may be appropriate for algal blooms). The model estimates approximately 28 days where chlorophyll $a$ concentrations exceed $30 \mu \mathrm{g} / \mathrm{L}$ (severe algal blooms are likely), and about 11 days where chlorophyll $a$ concentrations exceed $40 \mu \mathrm{g} / \mathrm{L}$ (severe algal blooms) (table 13).
However, if phosphorus and nitrogen loading to Silver Lake decreases, the number of days that algal blooms may be present also would decrease. If the phosphorus and nitrogen loading from Hunter Creek is decreased (and all other sources are not altered), Silver Lake will continue to experience algal blooms but less frequently that what is experienced currently. On the other hand, if nutrient loads increase from Hunter Creek, Silver Lake will experience more frequent and more intense algal blooms (table 13). If the nutrient loading from groundwater alone was decreased, the overall impact on Silver Lake would not be as effective at reducing algal bloom frequency as the reduction of nutrient loading from Hunter Creek. The same scenario applies if phosphorus and nitrogen loading from groundwater were increased.

The third scenario includes an increase and decrease in phosphorus and nitrogen loading from nutrient sources that are the most likely to be managed and include groundwater, Hunter Creek, and lawn runoff. According to the BATHTUB model, a 50-percent reduction of phosphorus and nitrogen from all three of these sources would result in a considerable decrease in algal bloom frequency (from 231 to 132 days) and severity, and a 75-percent reduction would greatly reduce algal bloom occurrence on Silver Lake (from 231 to 57 days) with severe algal blooms essentially eliminated (chlorophyll $a>30 \mu \mathrm{g} / \mathrm{L}$, from 231 days to 1 day) (table 13).

\section{Reduced Septic Input to Silver Lake}

By using the range of SR values and the range of potential Es values, load scenarios from septic systems to Silver Lake and to nearby tributaries to Silver Lake were estimated. A summary of the medium (most likely), low, and high estimates for septic loads to Silver Lake are presented in table 10.

The observed load of phosphorus and nitrogen from both groundwater and streams to Silver Lake is likely conservative. As indicated in the Study Methods and Sampling Sites section, two of the monitoring wells (east and west) were placed in zones of low expected septic contamination, while two wells (north and south) were placed in areas of high expected septic contamination. Septic loading models from the south, east, and north wells' groundwater contribution area were all calibrated to observed data by adjusting the SR value until the model predicted an observed background value for each well. By placing wells in zones of high and low expected loads, our monitoring program likely provides a robust description of the median septic contributions to shallow groundwater adjacent to Silver Lake.

Scenarios were also run using the BATHTUB model to predict the effect of eliminated septic load to Silver Lake as a result of sewer installation. These scenarios were based on the low, medium (most likely), and high estimates for septic loads from both groundwater and surface water sources, including Hunter Creek, as summarized in table 10. Figure 21 illustrates the modeled impact of the conversion of septic systems to sewer on the trophic status of Silver Lake using the BATHTUB model. 
Table 13. Simulated algal bloom frequency for Silver Lake,

Oceana County, Michigan, in response to changes in phosphorus and nitrogen loading scenarios.

$[\mu \mathrm{g} / \mathrm{L}$, micrograms per liter; >, greater than]

\begin{tabular}{|c|c|c|c|}
\hline \multirow{2}{*}{$\begin{array}{l}\text { Change in } \\
\text { nutrient } \\
\text { concentration, } \\
\text { in percent }\end{array}$} & \multicolumn{3}{|c|}{$\begin{array}{c}\text { Number of days per year with algal blooms } \\
\text { by load adjustment scenario }\end{array}$} \\
\hline & Groundwater & Hunter Creek & $\begin{array}{l}\text { Combination of } \\
\text { groundwater, } \\
\text { Hunter Creek, } \\
\text { and lawn runoff }\end{array}$ \\
\hline \multicolumn{4}{|c|}{ Chlorophyll $a,>10 \mu \mathrm{g} / \mathrm{L}$} \\
\hline-75 & 181 & 152 & 57.3 \\
\hline-50 & 200 & 187 & 132 \\
\hline-25 & 217 & 212 & 190 \\
\hline 0 & 231 & 231 & 231 \\
\hline 25 & 243 & 246 & 260 \\
\hline 50 & 254 & 259 & 280 \\
\hline 75 & 264 & 269 & 295 \\
\hline 100 & 272 & 278 & 307 \\
\hline \multicolumn{4}{|c|}{ Chlorophyll $a_{1}>20 \mu \mathrm{g} / \mathrm{L}$} \\
\hline-75 & 47.1 & 33.6 & 6.2 \\
\hline-50 & 58.4 & 50.4 & 25.6 \\
\hline-25 & 69.4 & 65.7 & 52.2 \\
\hline 0 & 79.6 & 79.6 & 79.6 \\
\hline 25 & 89.8 & 92.3 & 105 \\
\hline 50 & 99.6 & 104 & 128 \\
\hline 75 & 109 & 115 & 147 \\
\hline 100 & 118 & 125 & 164 \\
\hline \multicolumn{4}{|c|}{ Chlorophyll $a,>30 \mu \mathrm{g} / \mathrm{L}$} \\
\hline-75 & 13.5 & 8.8 & 1.1 \\
\hline-50 & 17.9 & 14.9 & 6.2 \\
\hline-25 & 23.0 & 21.2 & 15.7 \\
\hline 0 & 27.7 & 27.7 & 27.7 \\
\hline 25 & 32.9 & 34.3 & 41.2 \\
\hline 50 & 38.0 & 40.5 & 54.4 \\
\hline 75 & 43.1 & 46.7 & 67.5 \\
\hline 100 & 48.2 & 52.9 & 79.6 \\
\hline \multicolumn{4}{|c|}{ Chlorophyll $a,>40 \mu \mathrm{g} / \mathrm{L}$} \\
\hline-75 & 4.4 & 2.6 & 0.4 \\
\hline-50 & 6.2 & 5.1 & 1.8 \\
\hline-25 & 8.4 & 7.7 & 5.5 \\
\hline 0 & 10.6 & 10.6 & 10.6 \\
\hline 25 & 13.1 & 13.5 & 17.2 \\
\hline 50 & 15.7 & 16.8 & 24.1 \\
\hline 75 & 18.3 & 20.1 & 31.8 \\
\hline 100 & 20.8 & 23.4 & 39.1 \\
\hline
\end{tabular}



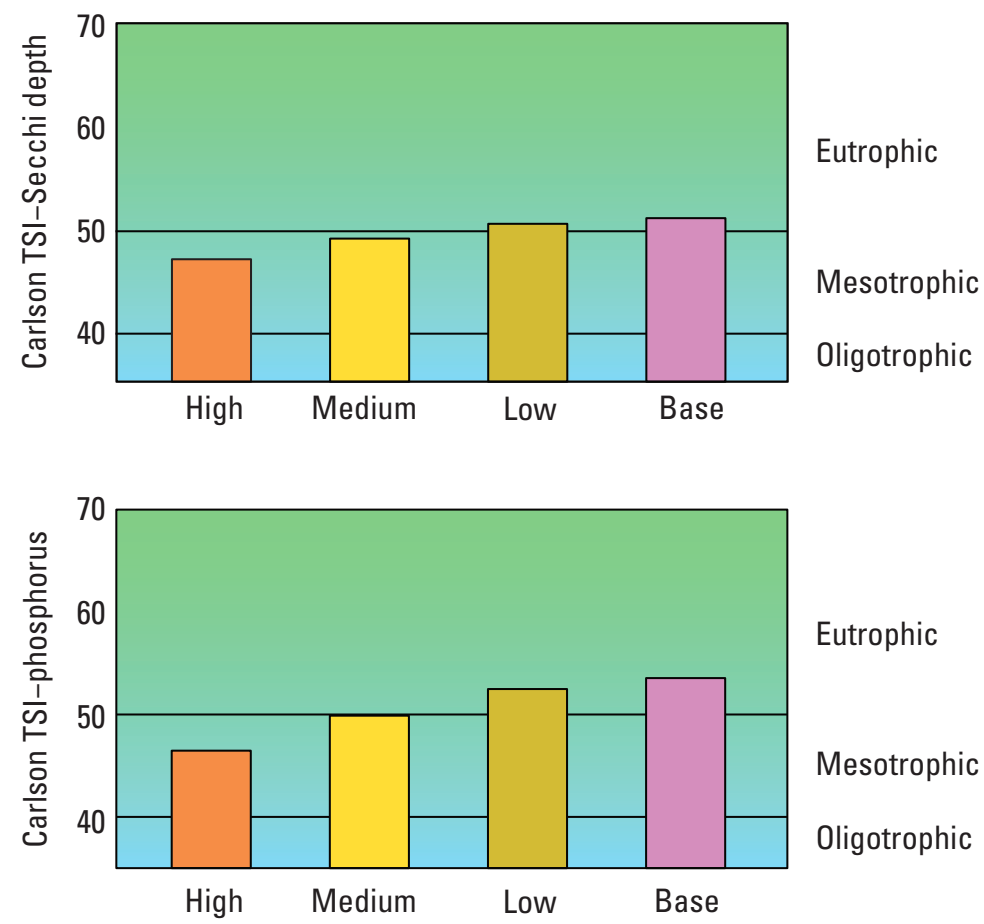

Eutrophic

Mesotrophic

Oligotrophic

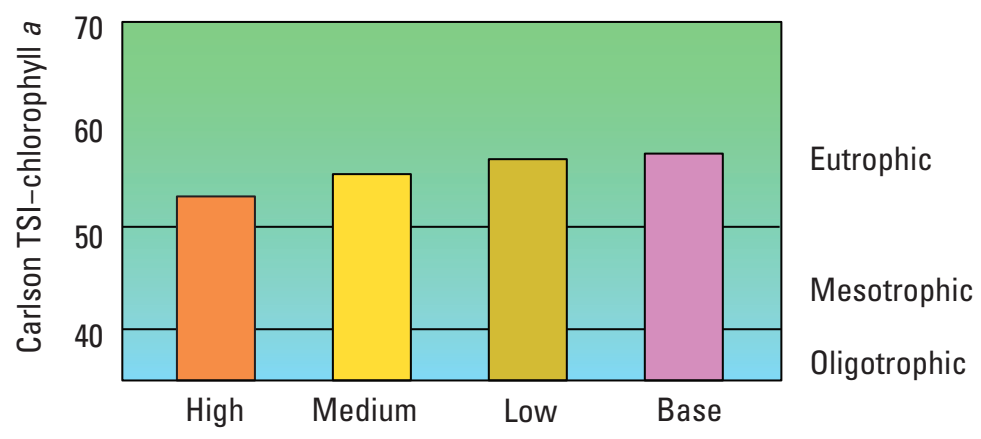

\section{EXPLANATION}

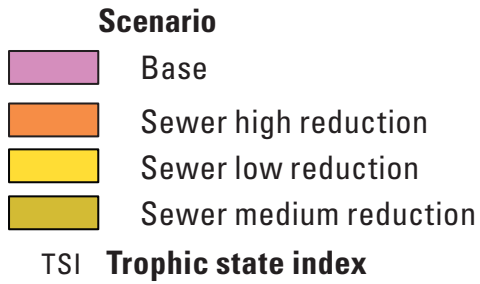

Figure 21. Simulated effect of conversion from onsite septic-waste treatment (within 200 feet of shoreline) to central sewer system using BATHTUB. (Based on Carlson's Trophic State Index (TSI) values, less than 40 represents oligotrophic conditions, 40-50 mesotrophic, and greater than 50 represents eutrophic conditions.)

Simple septic models have demonstrated that a large proportion of the phosphorus load in groundwater and Hunter Creek is likely contributed by septic systems. The septic model provides a possible range of septic loading based on the uncertainty in the load going to septic tanks and the variability of soil retention (based on septic system function). The BATHTUB model was used to evaluate the elimination of septic as a source to both groundwater and all tributaries based on the low, medium (most likely), and high loading scenarios. The BATHTUB model predicted reductions in the total phosphorus load to the lake of 9.8-48.4 percent, and simultaneous reductions in nitrogen of $0.2-2.8$ percent (fig. 21). The septic-removal simulation using the likely septic-load scenario indicates that a complete removal of septic systems would improve the lake to an average mesotrophic condition. The high-septic-load scenario shows a greater improvement in trophic status, while the low-septic-load scenario indicates an improvement in lake trophic status that ranges from mesotrophic to eutrophic (fig. 21). Therefore, based on the previous BATHTUB scenarios, it is likely that the elimination of septic influence to the lake would improve the average trophic status of Silver Lake to mesotrophic. 
Based on the BATHTUB model, the number of days that Silver Lake would experience algal blooms (under the medium, or most likely, septic scenario), would decrease from the current estimated 231 days (chlorophyll $a>10 \mu \mathrm{g} / \mathrm{L}$ ) to 184 days, or from 80 days (chlorophyll $a>20 \mu \mathrm{g} / \mathrm{L}$ ) to 49 days. According to the high septic efficiency model, algal bloom occurrence (chlorophyll $a>10 \mu \mathrm{g} / \mathrm{L}$ ) would decrease from the current status to 132 days, and based on the low septic efficiency model, algal bloom occurrence would decrease to 219 days. Using the nutrient source loading information provided in table 10, the BATHTUB model indicates that the conversion of onsite septic treatment to sewers would result in an overall improvement in lake trophic status and greatly reduce the frequency of algal blooms and algal bloom intensity on Silver Lake.

\section{Summary and Conclusions}

Silver Lake is a 672-acre inland lake located in Oceana County, Michigan, and is a major tourist destination due to its proximity to Lake Michigan and the surrounding outdoor recreational opportunities. In recent years, Silver Lake exhibited patterns of high phosphorus concentrations, elevated chlorophyll $a$ concentrations, and nuisance algal blooms. Previous studies conducted indicated that Silver Lake was experiencing advanced eutrophication and more frequent algal blooms in recent years. As a result, the Silver Lake Improvement Board (SLIB) concluded that a detailed interpretive study was necessary. The U.S. Geological Survey (USGS), in cooperation with the Silver Lake Improvement Board and in collaboration with the Annis Water Resources Institute (AWRI) of Grand Valley State University, designed a study to assess the hydrologic and nutrient inputs to Silver Lake, as well as identify the conditions that affect the nutrient chemistry and production of algal blooms in the lake. This information can inform water-resource managers in developing various management strategies to prevent or reduce the occurrence of future algal blooms.

USGS and AWRI scientists collected data from November 2012 to December 2014 to provide information for future management decisions for Silver Lake. Silver Lake can be classified as a polymictic (well mixed) lake with a residence time of approximately 223 days.

On an annual basis, the primary contributor of water to Silver Lake is Hunter Creek, at 52.2 percent. Other water sources include groundwater (30.6 percent), direct precipitation (10.3 percent), the tributary at the State Park (4.1 percent), and the tributary at North Shore Drive (2.8 percent). During the spring season, Hunter Creek is the dominant source (62.6 percent) of water to the lake; however, in the summer the primary contributor of water to the lake becomes groundwater (43.7 percent). In the fall, both Hunter Creek and groundwater contribute similar proportions (42.8 and 36.5 percent, respectively) of the overall water budget and during winter Hunter
Creek again becomes the dominant source (54.9 percent) of water to the lake. The primary component of water loss from Silver Lake is the outflow of water from Silver Lake via Silver Creek, which accounts for 91.9 percent of all water leaving Silver Lake. The remaining 8.1 percent is lost through evaporation.

Study results indicated that Silver Lake is colimited by both phosphorus and nitrogen, based on both the bioassay results and the nitrogen:phosphorus ratios in the lake. As a result, both phosphorus and nitrogen are deemed critical nutrients in the development of algal blooms and lake eutrophication. Although this colimitation indicates that both nitrogen and phosphorus are needed to produce excessive algal growth during the summer months, it does not indicate that both nutrients must be reduced to control algal blooms. Study results indicate that the largest controllable nutrient to Silver Lake is phosphorus.

Based on the average total phosphorus and total nitrogen concentrations in Silver Lake and the U.S. Environmental Protection Agency (EPA) nutrient criteria recommendation for phosphorus and nitrogen, the lake is classified as eutrophic. Silver Lake also was classified as eutrophic using Carlson's TSI approximately 63 percent of the time (five sampling events), mesotrophic to slightly eutrophic approximately 25 percent of the time (two sampling events), and oligotrophic to slightly mesotrophic about 13 percent of the time (one sampling event).

The likely contribution of phosphorus and nitrogen from septic systems was computed by using a model for septic transport, because septic systems sited on the lakeshore could be important sources of the phosphorus and nitrogen observed in shallow groundwater. This septic model considers the number of residences within 200 feet (ft) of the shore of the lake or surface waters that drain to the lake. Septic systems further than $200 \mathrm{ft}$ from the lake still have an expected impact, but because of the longer travel distance and larger area of diffusion from these systems, the uncertainty in the estimation of their loads is too large to produce a reliable number. Further, the model included only personal residences in the septic model estimates, not commercial facilities such as campgrounds and hotels within $200 \mathrm{ft}$ of the shoreline and Hunter Creek, because the septic model was not designed to accurately represent commercial facilities. If commercial facilities were included, the estimated impact (nutrient loading) of septic systems to the lake and Hunter Creek would be higher. It should be noted, however, that commercial and residential septic sources further than $200 \mathrm{ft}$ from the lake are still captured in the nutrient budget from the groundwater well monitoring that includes nearby (within $200 \mathrm{ft}$ ) and diffuse (further than $200 \mathrm{ft}$ ) septic sources. As a result of these constraints, the amounts of phosphorus and nitrogen being contributed directly to the lake or tributaries to the lake, as computed using this model, are likely a conservative estimation (an underestimation) of the actual phosphorus and nitrogen loads contributed by all of the septic systems around the lake. The septic model estimated that septic systems likely contributed 47.8 percent 
(300.9 pounds [lbs]) of phosphorus and 1.1 percent $(136.1 \mathrm{lb})$ of nitrogen to groundwater annually. Study findings indicate that much of the phosphorus contribution to Silver Lake via groundwater is orthophosphate, a form of phosphorus that can readily stimulate algae growth.

The mean annual input of phosphorus to Silver Lake was approximately $1,342 \mathrm{lb}$. The major pathways of phosphorus to Silver Lake were groundwater (46.9 percent), followed by Hunter Creek (28.7 percent). However, 19.5 to 73.7 percent of phosphorus in groundwater and 2.1 to 43.6 percent of phosphorus in Hunter Creek is likely derived from septic loading, indicating that septic loading is the largest potentially controllable nutrient load modeled in this study. The largest loading of phosphorus to Silver Lake occurred in the spring months, followed by the summer and fall. Of the total $1,342 \mathrm{lb}$ of phosphorus that entered Silver Lake annually (mean), almost all of the phosphorus was exported out of the lake $(1,340 \mathrm{lb})$, with minimal phosphorus deposition occurring in the lakebed sediment.

The mean annual input of nitrogen to Silver Lake was approximately $51,998 \mathrm{lb}$. The major sources of nitrogen to Silver Lake were Hunter Creek (56.3 percent), groundwater (24.9 percent), and atmospheric deposition ( 8.8 percent). The septic model loading scenarios indicate that septic systems account for 0.05 to 3.1 percent of the load to Hunter Creek, and 0.23 to 2.8 percent of the contribution of nitrogen to groundwater. The largest nitrogen loading to Silver Lake was observed during the spring, followed by the summer and fall months. About twice as much nitrogen entered Silver Lake during the spring $(19,180 \mathrm{lb})$ as compared to the fall months $(8,921 \mathrm{lb})$. Of the $51,998 \mathrm{lb}$ of nitrogen that entered Silver Lake annually (mean), approximately 42.2 percent $(21,928 \mathrm{lb})$ of nitrogen was deposited in the lakebed sediment according to the BATHTUB model.

The data collected as part of this study were used to model future nutrient loading and eutrophication scenarios using the BATHTUB model developed by the U.S. Army Corps of Engineers. Both phosphorus and nitrogen constituents were altered in the various nutrient-loading scenarios. Based on Carlson's trophic state index (TSI), the baseline calibrated dataset for the model indicated that Silver Lake was eutrophic, and thus all of the nutrient loading scenarios began with the lake being eutrophic. BATHTUB model simulations indicate that if phosphorus and nitrogen loading from groundwater were decreased by 75 percent, and all of the other nutrient inputs stayed the same, the condition of Silver Lake would most likely range from highly mesotrophic to eutrophic (the current [2014] condition of Silver Lake). This result also applies to the same scenario of nutrient loading from Hunter Creek. If nutrient loading continued to increase in groundwater or Hunter Creek, the lake would continue to remain eutrophic with more frequent algal blooms. Therefore, BATHTUB model simulations indicate that the reduction of nutrients from either Hunter Creek or groundwater alone may not be enough to effectively improve the trophic status and related water-quality issues in Silver Lake. However, if phosphorus and nitrogen from a combination of sources (groundwater, Hunter Creek, and lawn runoff) were reduced by 75 percent, then Silver Lake could be classified as mesotrophic based on Carlson's three TSI equations.

The reduction of phosphorus and nitrogen from either of the small tributaries was not significant enough to modify the trophic status of the lake. The model output indicated that Silver Lake would remain eutrophic, even with a 75-percent reduction of phosphorus and nitrogen from these sources.

If the phosphorus and nitrogen loading from Hunter Creek is decreased (and all other sources are not altered), Silver Lake will continue to experience algal blooms but less frequently than what is currently experienced. On the other hand, if nutrient loads increase from Hunter Creek, Silver Lake will experience more frequent and more intense algal blooms. If the nutrient loading from groundwater alone were decreased, the overall impact on Silver Lake would not be as effective at reducing algal bloom frequency as the reduction of nutrient loading from Hunter Creek alone. A third scenario includes an increase and decrease in phosphorus and nitrogen loading from nutrient sources that are the most likely to be managed and include groundwater (sewer installation), Hunter Creek (sewer installation and riparian best management practices [BMPs]), and lawn runoff (fertilizer BMPs). BATHTUB model simulations indicate that a 50-percent reduction of phosphorus and nitrogen from these sources would result in a considerable decrease in algal bloom frequency and severity, and a 75-percent reduction would greatly reduce algal bloom occurrence on Silver Lake.

A scenario also was conducted using the BATHTUB model to simulate the conversion of septic to sewer and included a high, low, and medium (most likely) scenario for both phosphorus and nitrogen loading to Silver Lake. The BATHTUB model simulation indicated that the conversion of onsite septic treatment to sewers would result in an overall change in lake trophic status from eutrophic to mesotrophic, and greatly reduce the frequency of algal blooms and algal bloom intensity on Silver Lake. According to the BATHTUB model, the installation of a sewer system may eliminate the largest phosphorus load modeled in the study and thus improve the trophic status of Silver Lake.

It is important to note that the reduction of the productivity in lakes by decreasing nutrient loading can be very effective; however, the rate at which the productivity of the lake will revert toward conditions existing prior to increased loading is variable. In other words, it took time for Silver Lake to become eutrophic, and it will take time for the lake to begin to recover after phosphorus and nitrogen loading from the lake's major nutrient sources is addressed. The local residents and businesses, as well as local government agencies, will need to determine the best management strategy or strategies to address the major nutrient contributions to Silver Lake. 


\section{References Cited}

Boström, B., Jansson, M., and Forsberg, C., 1982, Phosphorus release from lake sediments: Archiv fur HydrobiologieBeiheft Ergebnisse der Limnologie, v. 18, p. 5-59.

Briggs, M.A., Voytek, E.B., Day-Lewis, F.D., Rosenberry, D.O., and Lane, J.W., 2013, Understanding water column and streambed thermal refugia for endangered mussels in the Delaware River: Environmental Science and Technology, v. 47, no. 20, p. 11423-11431.

Canter, L.W., and Knox, R.C, 1985, Septic tank system effects on ground water quality: Lewis Publishers Inc., 360 p.

Carlson, R.E., 1977, A trophic state index for lakes: Limnology and Oceanography, v. 22, no. 2, p. 361-369.

Clescerl, L.S., Greenberg, A.E., and Eaton, A.D., eds. 1999, Standard methods for the examination of water and wastewater (20th ed.): Washington, D.C., American Public Health Association, 1,325 p.

Conley, D.J., Paerl, H.W., Howarth, R.W., Boesch, D.F., Seitzinger, S.P., Havens, K.E., Lancelot, Christiane, and Likens, G.E., 2009, Controlling eutrophication-Nitrogen and phosphorus: Science, v. 323, no. 5917, p. 1014-1015.

Curtis, P.N.; Rife, Troy; Lambert, Scott; and Pellow, Josh, 2012, Silver Lake State Park - General management plan: Lansing, Mich., Michigan Department of Natural Resources, $91 \mathrm{p}$.

DeJong, W.S., 2015, Silver Lake area demographic analysisGolden Township, Oceana County, Michigan: Mears, Mich., Friends of Silver Lake, $77 \mathrm{p}$.

eBird, 2015, eBird-An online database of bird distribution and abundance: Ithaca, New York, accessed February 12, 2015, at http://www.ebird.org.

Fetter, C.W., 1994, Applied Hydrogeology (3d ed.): Englewood Cliffs, N.J., Prentice-Hall, 691 p.

Fisher, M.M., Brenner, Mark, and Reddy, K.R., 1992, A simple, inexpensive piston corer for collecting undisturbed sediment/water interface profiles: Journal of Paleolimnology, v. 7, p. 157-161.

Fishman, M.J., ed., 1993, Methods of analysis by the U.S. Geological Survey National Water Quality LaboratoryDetermination of inorganic and organic constituents in water and fluvial sediments: U.S. Geological Survey OpenFile Report 1993-125, 217 p.
Fry, J.A., Xian, G., Jin, S., Dewitz, J.A., Homer, C.G., Yang, L., Barnes, C.A., Herold, N.D., and Wickham, J.D., 2011, Completion of the 2006 National Land Cover Database for the conterminous United States: Photogrammetric Engineering and Remote Sensing, v. 77, no. 9, p. 858-864.

Fuller, L.M., and Taricska, C.K., 2012, Water-quality characteristics of Michigan's inland lakes, 2001-10: U.S. Geological Survey Scientific Investigations Report 2011-5233, 53 p., plus CD-ROM.

Fusilier, W., and Fusilier, B., 2001, Silver Lake-A water quality and watershed management study: Water Quality Investigators, Dexter, Mich., 267 p.

Garn, H.S., 2002, Effects of lawn fertilizer on nutrient concentration in runoff from lakeshore lawns, Lauderdale Lakes, Wisconsin: U.S. Geological Survey Water-Resources Investigation Report 2002-4130, 6 p.

Garn H.S., Robertson, D.M., Rose, W.J., Goddard, G.L., and Horwatich, J.A., 2006, Water quality, hydrology, and response to changes in phosphorus loading of Nagawicka Lake, a calcareous lake in Waukesha County, Wisconsin: U.S. Geological Survey Scientific Investigations Report 2006-5273, 41 p.

Garn, H.S., Seidel, T.L., and Rose, W.J., 1996, Hydrology and water quality of Lauderdale Lakes, Walworth County, Wisconsin, 1993-94: U.S. Geological Survey Water-Resources Investigations Report 96-4235, 29 p.

Greenberg, A.E., 1992, Standard methods for the examination of water and wastewater (18th ed.): Washington, D.C., American Public Health Association, 1,100 p.

Groves, Tony; Tyning, Pam; and Meyers, Tory, 2013, Lake mapping-An overview of methods and potential uses: Water Resources Group, Progressive AE, 4 p., accessed August 14, 2015, at http://michiganlakeinfo.com/Lake Mapping.html.

Guo, Danlu, and Westra, Seth, 2015, EvapotranspirationEstimating potential and actual evapotranspiration with multiple models (R package ver. 1.5), accessed August 14, 2015, at https://cran.r-project.org/web/packages/Evapotranspiration/index.html.

Guy, H.P., 1969, Laboratory theory and methods for sediment analysis: U.S. Geological Survey Techniques of WaterResources Investigations, book 5, chap. C1, $58 \mathrm{p}$.

Harpole, W.S., Ngai, J.T., Cleland, E.E., Seabloom, E.W., Borer, E.T., Bracken, M.E.S., Elser, J.J., Gruner, D.S., Hilliebrand, Helmut, Shurin, J.B., and Smith J.E., 2011, Nutrient co-limitation of primary producer communities: Ecology Letters, v. 14 , no. 9, p. 852-862. 
Helsel, D.R. and Hirsch, R.M., 2002, Statistical methods in water resources: U.S. Geological Survey Techniques of Water-Resources Investigations, book 4, chapter A3, 522 pages.

Hunt, R.J., Greb, S.R., and Graczyk, D.J., 2006, Evaluating the effects of nearshore development on Wisconsin Lakes: U.S. Geological Survey Fact Sheet 2006-3033, 4 p.

Jensen, H.S., Kristensen, P., Jeppesen, E., and Skytthe, A., 1992, Iron:phosphorus ratio in surface sediment as an indicator of phosphate release from aerobic sediments in shallow lakes: Hydrobiologia, v. 235-236, no. 1, p. 731-743.

Jensen, M.E., and Haise, H.R., 1963, Estimating evapotranspiration from solar radiation: Proceedings of the American Society of Civil Engineers, Journal of the Irrigation and Drainage Division, v. 89, p. 15-41.

Lewis, W.M., Jr., Grant, M.C., and Hamilton, S.K., 1985, Evidence that filterable phosphorus is a significant atmospheric link in the phosphorus cycle: Oikos, v. 45 , no. 3 , p. $428-432$.

Maloney, T.J., ed., 2005, Quality management system, U.S. Geological Survey National Water Quality Laboratory: U.S. Geological Survey Open-File Report 2005-1263, version 1.3, 9 November 2005, chapters and appendixes variously paged.

Manny, B.A., Johnson, W.C., and Wetzel, R.G., 1994, Nutrient additions by waterfowl to lakes and reservoirs-Predicting their effects on productivity and water quality: Hydrobiologia, v. 279-280, p. 121-132.

Michigan Department of Environmental Quality, 2013, Nutrient criteria-Nutrient framework to reduce phosphorus and nitrogen pollution, accessed June 2013 at http://www. michigan.gov/documents/deq/wrd-nutrient-frameworkcriteria_429128_7.pdf.

Michigan Department of Environmental Quality-Surface Water Quality Division, 2001, Total Maximum Daily Load (TMDL) for total phosphorus in Lake Allegan, 9 p., accessed August 17, 2015, at http://www.michigan.gov/ documents/deq/wrd-swas-tmdl-allegan_450908_7.pdf.

Michigan Department of Natural Resources, 1982, Michigan Inland Lake Project-Identification, survey, and classification: Clean Lakes Agreement No. S 005511-01, 20 p., plus apps.

Michigan State University, 2015, Enviro-weather-Weatherbased pest, natural resources, and production management tools, accessed March 2015 at http://www.enviro-weather. msu.edu/homeMap.php.
Moore, P.A., Reddy, K.R., and Fisher, M.M., 1998. Phosphorus flux between sediment and overlying water in Lake Okeechobee, Florida: spatial and temporal variations. Journal of Environmental Quality, 27(6), 1428-1439.

National Oceanic and Atmospheric Administration, 2013, Climate data online, accessed August 17, 2015, at http://www.ncdc.noaa.gov/cdo-web/.

Oregon Department of Environmental Quality, 2011, Estimation of nitrogen sources, nitrogen applied, and nitrogen leached to groundwater in the lower Umatilla Basin groundwater management area, 21 p., accessed August 17, 2015, at http:/www.deq.state.or.us/er/reports/11 er001.pdf.

Progressive AE, 2011, Silver Lake 2011 water quality monitoring report: Grand Rapids, Mich., Project no. 50740101, 34 p., accessed August 17, 2015, at http://www.friendsofsilverlake.org/reports-maps/.

R Development Core Team, 2012, R-A language and environment for statistical computing: Vienna, Austria, R Foundation for Statistical Computing, accessed August 17, 2015, at http://www.R-project.org.

Reckhow, K.H., Beaulac, M.N., and Simpson, J.T., 1980, Modeling phosphorus loading and lake response under uncertainty - A manual and compilation of export coefficients: Washington, D.C., U.S. Environmental Protection Agency, EPA-440/5-80-011, 214 p.

Robertson, D.M., Rose, W.J., and Garn, H.S., 2003, Water quality and the effects of changes in phosphorus loading, Red Cedar Lakes, Barron and Washburn Counties, Wisconsin: U.S. Geological Survey Water-Resources Investigations Report 2003-4238, 42 p.

Robertson, D.M., Rose, W.J., and Juckem, P.F., 2009, Water quality and hydrology of Whitefish (Bardon) Lake, Douglas County, Wisconsin, with special emphasis on responses of an oligotrophic seepage lake to changes in phosphorus loading and water level: U.S. Geological Survey Scientific Investigations Report 2009-5089, 41 p.

Robertson, W.D., Schiff, S.L., and Ptacek, C.J., 1998, Review of phosphate mobility and persistence in 10 septic system plumes: Ground Water, v. 36, no. 6, p. 1000-1010.

Rose, J.B., and Shibata, T., 2006, A pilot study-Silver Lake water quality: Lansing, Mich., Michigan State University, Department of Fisheries \& Wildlife, Microbiological Water \& Health Laboratory, 13 p.

Rosenberry, D.O., and LaBaugh, J.W., 2008, Field techniques for estimating water fluxes between surface water and ground water: U.S. Geological Survey Techniques and Methods 4-D2, $128 \mathrm{p}$. 
Rosenberry, D.O., Stannard, D.I., Winter, T.C., and Martinez, M.L., 2004, Comparison of 13 equations for determining evapotranspiration from a prairie wetland, Cottonwood Lake area, North Dakota, USA: Wetlands, v. 24, no. 3, p. 483-497.

Rydin, Emil, Huser, B.J., and Welch, E.B., 2000, Amount of phosphorus inactivated by alum treatments in Washington lakes: Limnology and Oceanography, v. 45, no. 1, p. 226-230.

Shreve, E.A., and Downs, A.C., 2005, Quality-assurance plan for the analysis of fluvial sediment by the U.S. Geological Survey Kentucky Water Science Center Sediment Laboratory: U.S. Geological Survey Open-File Report 2005-1230, $28 \mathrm{p}$.

Steinman, A.D., Chu, Xuefeng, and Ogdahl, M.E., 2009, Spatial and temporal variability of internal and external phosphorus loads in Mona Lake, Michigan: Aquatic Ecology, v. 43, no. 1, p. 1-18.

Steinman, A.D., and Ogdahl, M.E., 2008, Ecological effects after an alum treatment in Spring Lake, Michigan: Journal of Environmental Quality, v. 37, no. 1, p. 22-29.

Steinman, A.D., and Ogdahl, M.E., 2012, Macroinvertebrate response and internal phosphorus loading in a Michigan Lake after alum treatment: Journal of Environmental Quality, v. 41, no. 5, p. 1540-1548.

Steinman, A.D., and Ogdahl, M.E., 2015, TMDL reevaluation-Reconciling internal phosphorus load reductions in a eutrophic lake: Lake and Reservoir Management, v. 31, no. 2, p. 115-126.

Steinman, A.D., Ogdahl, M.E., and Ruetz, C.R., III, 2011, An environmental assessment of a small, shallow lake (Little Black Lake, MI) threatened by urbanization: Environmental Monitoring and Assessment, v. 173, p. 193-209.

Steinman, A.D.; Rediske, Rick; Denning, Rod; Nemeth, Lori; Chu, Xuefeng; Uzarski, Don; Biddanda, Bopi; and Luttenton, Mark, 2006, An environmental assessment of an impacted, urbanized watershed-The Mona Lake Watershed, Michigan: Archiv für Hydrobiologie, v. 166, no. 1, p. 117-144.

Steinman, A.D., Rediske, Rick, and Reddy, K.R., 2004, The reduction of internal phosphorus loading using alum in Spring Lake, Michigan: Journal of Environmental Quality, v. 33, no. 6, p. 2040-2048.

Stynes, D.J., 2002, Michigan statewide tourism spending and economic impact estimates, 1998-2000, accessed August 21, 2015, at http://www.tourismcenter.msu.edu/VirtualTourism/MichiganSatExec.pdf.
Turnipseed, D.P., and Sauer, V.B, 2010, Discharge measurements at gaging stations: U.S. Geological Survey Techniques and Methods, book 3, chap. A8, 87 p. (Also available at http://pubs.usgs.gov/tm/tm3-a8/.)

U.S. Census Bureau, 2011, Age and sex composition-2010, accessed August 17, 2015, at http://www.census.gov/prod/ cen2010/briefs/c2010br-03.pdf.

U.S. Department of Agriculture National Agriculture Imagery Program, 2014, accessed as ArcGIS Image Service at http://gis.apfo.usda.gov/arcgis/services/NAIP/ Michigan_2014_1m/ImageServer.

U.S. Department of Agriculture-Natural Resources Conservation Service, 2015, Web soil survey for Oceana County, Michigan, accessed February 26, 2015, at http://websoilsurvey.sc.egov.usda.gov.

U.S. Environmental Protection Agency, 1983, Methods for chemical analysis of water and wastes: Washington, D.C., Office of Research and Development, EPA/600/4-79/020, $491 \mathrm{p}$.

U.S. Environmental Protection Agency, 2000a, Ambient water quality criteria recommendations - Information supporting the development of State and Tribal nutrient criteriaLakes and reservoirs in nutrient ecoregion VII: Office of Water, EPA 822-B-00-009, accessed August 21, 2015, at http://water.epa.gov/scitech/swguidance/standards/criteria/ library_index.cfm.

U.S. Environmental Protection Agency, 2000b, Ambient water quality criteria recommendations - Information supporting the development of State and Tribal nutrient criteria-Rivers and streams in nutrient ecoregion VII: Office of Water, EPA 822-B-00-018, 93 p, accessed August 21, 2015, at http://water.epa.gov/scitech/swguidance/standards/criteria/ nutrients/upload/2007_09_27_criteria_nutrient_ecoregions rivers_rivers_7.pdf.

U.S. Environmental Protection Agency, 2007, Test methods for evaluating solid waste, physical/chemical methods (SW-846) (rev. 2), accessed August 17, 2015, at http:// www.epa.gov/epawaste/hazard/testmethods/sw846/ pdfs/7000b.pdf.

U.S. Geological Survey, 2006, Collection of water samples (ver. 2.0): U.S. Geological Survey Techniques of WaterResources Investigations, book 9, chap. A4, September 2006, accessed February 4, 2015, at http://pubs.water.usgs. gov/twri9A4/.

U.S. Geological Survey, 2014, USGS Circular 1350-Nutrients in the Nation's streams and groundwater-Frequently asked questions, accessed February 4, 2015, at http://water. usgs.gov/nawqa/nutrients/pubs/circ1350/faq.html. 
U.S. Geological Survey, 2015a, The USGS water science school-Water color, accessed March 10, 2015, at http://water.usgs.gov/edu/color.html.

U.S. Geological Survey, 2015b, The USGS water science school-Nitrogen and water, accessed February 4, 2015, at http://water.usgs.gov/edu/nitrogen.html.

Verhougstraete, Marc; Singh, Shikha; Shibata, Tomoyuki; and Rose, J.B., 2007, Study of Silver Lake water quality: Lansing, Mich., Michigan State University, The Water Quality, Environmental, and Molecular Microbiological Laboratory, Department of Fisheries \& Wildlife, 14 p.

Walker, W.W., 1985, Empirical methods for predicting eutrophication in impoundments - Report 3-Model refinements: prepared for Office, Chief of Engineers, U.S. Army, Washington, D.C., Technical Report E-81-9, Vicksburg, Miss., U.S. Army Corps of Engineers, Waterways Experiment Station.
Walker, W.W., 1996, Simplified procedures for eutrophication assessment and prediction: Vicksburg, Miss., U.S. Army Corps of Engineers, Waterways Experiment Station, User Manual Instruction Report W-96-2 [variously paged].

Wetzel, R.G, 1983, Limnology (2d ed.): Philadelphia, Saunders College Publishing, 858 p.

Winter, T.C., Rosenberry, D.O., and Sturrock, A.M., 1995, Evaluation of 11 equations for determining evaporation for a small lake in the north central United States: Water Resources Research, v. 31, no. 4, p. 983-993, http://dx.doi. org/10.1029/94WR02537. 
Appendixes 1-3 


\section{Appendix 1. Estimation of Streamflow at Silver Lake Dam}

Water leaving Silver Lake through Silver Creek had to be accounted for in the water budget. To do this, the water level in the impoundment upstream from the Silver Lake Dam (fig. 2, table 2 in the main report) was monitored using a water-level sensor to measure changes in the water level above the dam. In addition, estimating streamflow required knowledge of the geometry of the dam, records of how the dam was operated, and manual measurements of streamflow downstream from the dam.

Water-level measurements in the Silver Lake Dam impoundment were collected from September 26, 2012, to October 1, 2014. The water levels were collected with reference to a gage datum of 579.85 feet (ft) above North American Vertical Datum of 1988 (NAVD 88). To obtain the elevation of the water in the impoundment in feet above NAVD 88, the gage height reported at the sensor is added to the reference value of $579.85 \mathrm{ft}$ above NAVD 88 . The gage height values for the impoundment are served online at http://waterdata.usgs. gov/mi/nwis/uv/?site_no=04122211\&agency_cd=USGS.

The next component needed to estimate flow was the geometry of the dam. The dam consists of four gates (fig. 1-1): two outer gates that are sluice gates and two inner gates that are overflow gates. The two inner gates may be manipulated by removing metal control boards that are $0.5 \mathrm{ft}$ in height. Engineering plans for the dam's construction were provided by Progressive AE (Tony Groves, Progressive AE, written commun., 2013). The engineering plans provided were referenced to an older vertical datum of National Geodetic Vertical Datum of 1929 (NGVD 29). Because the other gages used in this study were referenced to NAVD 88 , the elevations of the dam were converted to NAVD 88 by applying a correction of $-0.328 \mathrm{ft}$ to the NGVD 29 elevations. This correction factor was obtained from the National Geodetic Survey VERTCON site for orthometric height conversion (National Geodetic Survey, 2003). In addition, the elevation of the dam gates and the crest of the dam were surveyed using surveygrade global positioning system (GPS) to better correlate the elevation of the dam to the gage height elevation of water measured at the gage (U.S. Geological Survey (USGS) station number 04122211).

The operation of the dam was obtained through personal communication with the drain commissioner and a volunteer who assisted with maintenance of the dam. In the fall, two boards were removed from one of the inner gates to reduce water levels in the lake to their legal winter levels (Fusilier and Fusilier, 2001). In the spring, when high flows are common, there are periods where the sluice gates as well as the overflow gates are adjusted to help move water faster to Lake Michigan to prevent high water from damaging property in and around Silver Lake. Table 1-1 illustrates how the dam was adjusted during the period of study.

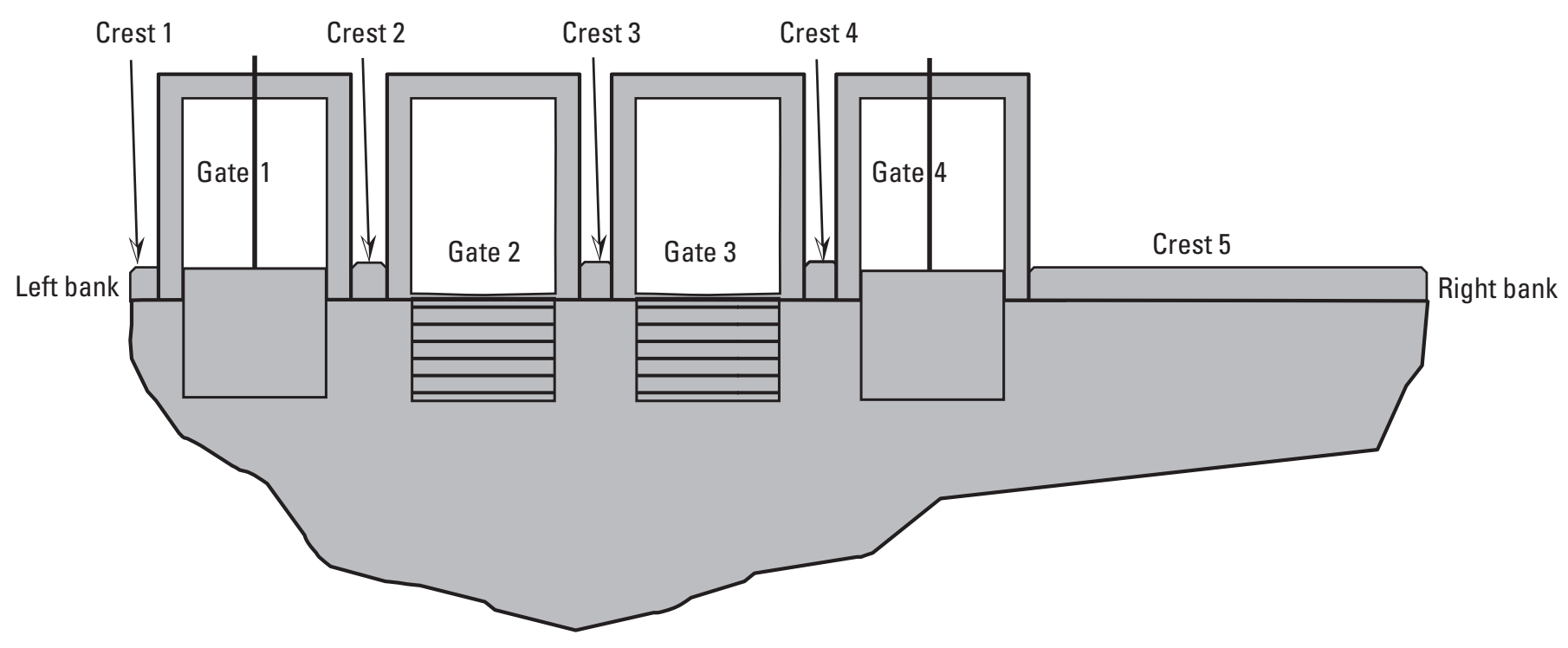

Figure 1-1. Approximate dam configuration for the Silver Lake Dam at Silver Creek, Oceana County, Michigan. 
Table 1-1. List of adjustments made to dam configuration during this study.

[-, no time recorded]

\begin{tabular}{|c|c|c|}
\hline $\begin{array}{c}\text { Date } \\
\text { (month/day/year) }\end{array}$ & $\begin{array}{l}\text { Approximate time } \\
\text { (24-hour clock) }\end{array}$ & Adjustment made \\
\hline \multicolumn{3}{|r|}{2012} \\
\hline $9 / 26 / 2012$ & - & All boards in at left and right sills, side gates completely closed. \\
\hline $10 / 10 / 2012$ & - & Two boards in overflow gate closest to left bank were removed. \\
\hline \multicolumn{3}{|r|}{2013} \\
\hline $4 / 15 / 2013$ & $12: 00$ & Open both sluice gates, $2-1 / 2$ inches each. \\
\hline $4 / 17 / 2013$ & $12: 00$ & Open both sluice gates to 6 inches each. \\
\hline $4 / 18 / 2013$ & $12: 00$ & Open both sluice gates to 11 inches each. \\
\hline $4 / 21-4 / 23 / 2013$ & - & Closed all gates, no time recorded. \\
\hline $5 / 6 / 2013$ & $11: 45$ & Put first board in for summer level in left overflow gate. \\
\hline $5 / 10 / 2013$ & $15: 50$ & Put in last board left overflow gate for summer lake level. \\
\hline $10 / 18 / 2013$ & $15: 15$ & Two boards in overflow gate closest to left bank were removed. \\
\hline \multicolumn{3}{|r|}{2014} \\
\hline $4 / 14 / 2014$ & $8: 45$ & Opened left and right sluice gates, about 1 foot each. \\
\hline $4 / 18 / 2014$ & 13:00 & Drain commissioner closed gates before the weekend. \\
\hline $4 / 21 / 2014$ & $15: 20$ & Drain commissioner opened sluice gates 1 foot. \\
\hline $4 / 22 / 2014$ & 15:00 & Sluice gates lowered 6-inch opening. \\
\hline $4 / 26 / 2014$ & $12: 58$ & Sluice gates were completely closed. \\
\hline $4 / 28 / 2014$ & $13: 50$ & Put first board in for summer level in left overflow gate. \\
\hline $5 / 9 / 2014$ & $17: 45$ & Opened the sluice gates, both sides, about 6-7 inches each. \\
\hline $5 / 12 / 2014$ & 11:00 & $\begin{array}{l}\text { Pulled out one board on the left overflow gate, and raised the left sluice } \\
\text { gate an additional } 2 \text { inches. }\end{array}$ \\
\hline $5 / 19 / 2014$ & $16: 40$ & Closed both sluice gates. \\
\hline $5 / 25 / 2014$ & $16: 35$ & Put first board in left overflow gate. \\
\hline $6 / 18 / 2014$ & 20:00 & Pulled out one board on the left overflow gate. \\
\hline $6 / 22 / 2014$ & $17: 00$ & Put first board in left overflow gate. \\
\hline $7 / 14 / 2014$ & $12: 00$ & Put last board in left overflow gate for summer lake level. \\
\hline
\end{tabular}




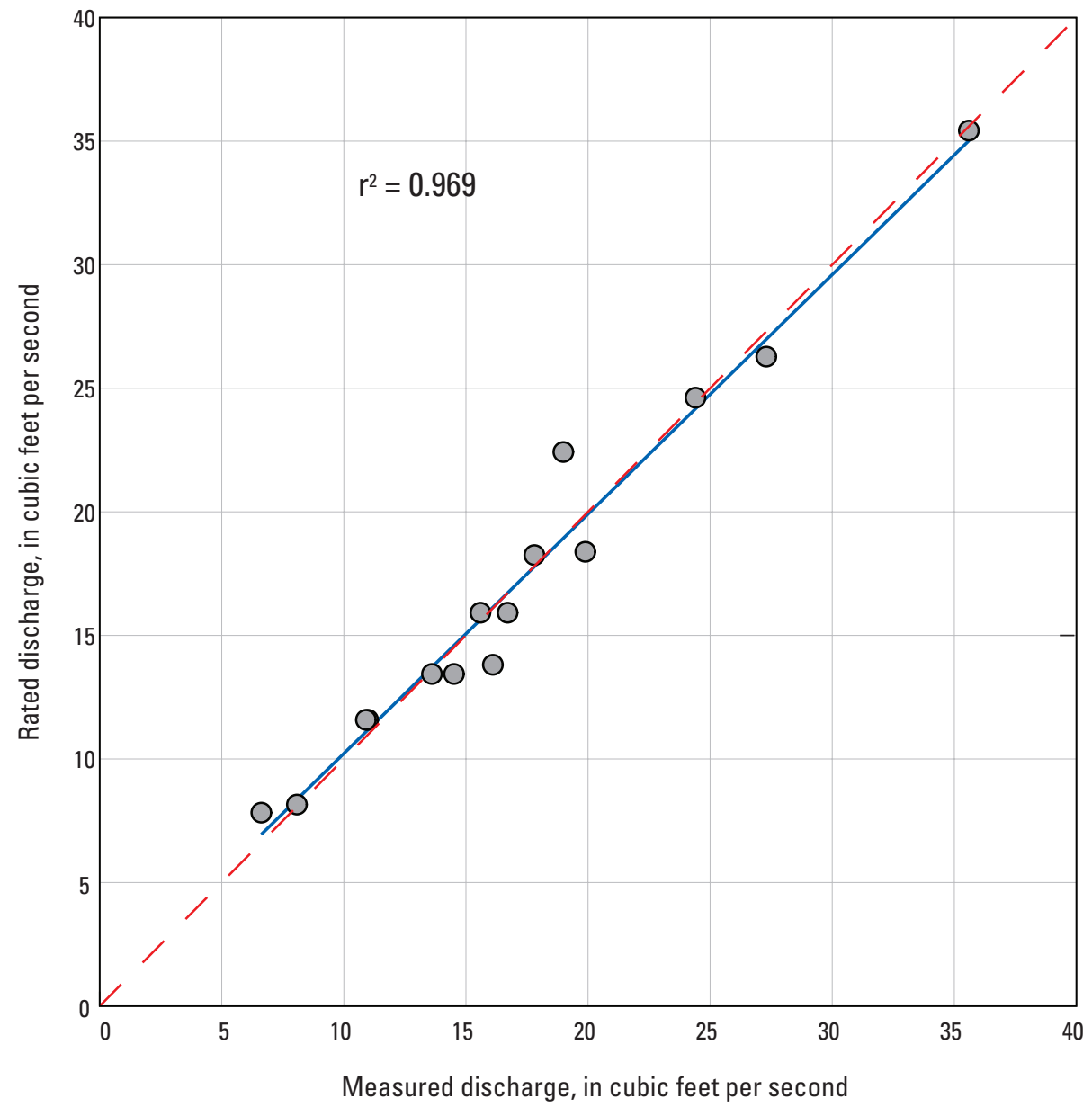

EXPLANATION

Discharge measurement

Linear fit of measured and rated discharge

- $1: 1$ line of identity

$r^{2}$ Coefficient of determination

Figure 1-2. Discharge rating for Silver Creek Dam, Oceana County, Michigan. 
To develop a rating, the dam was divided into the nine sections that can convey water. Those nine sections include four different gates and any overflow that goes over the five different crest sections of the dam (fig. 1-1). Each section was solved by an appropriate weir or sluice gate equation using the geometry of the dam, and the elevation of the water surface in the impoundment upstream from the dam. The results of each section were then summed to get the total estimated streamflow.

For the sluice gates (gates 1 and 4), the equation below described by Rouse and Howe (1953) was used to estimate the flow:

$$
Q=\frac{C_{c}}{\sqrt{1+C_{c}} b / h} b L \sqrt{2 g h}
$$

where

$$
\begin{array}{cl}
Q & \text { is streamflow, } \\
C_{c} & \text { is the coefficient of contraction, } \\
b & \text { is the height of gate opening, } \\
h & \text { is the head (water level) measured above the } \\
& \text { opening, } \\
L & \text { is the width of the gate, and } \\
g & \text { is the gravitational constant in square feet per } \\
& \text { second }
\end{array}
$$

Of those coefficients, $L, g$ and $C_{c}$ are held constant at $5 \mathrm{ft}$, 32.17 square feet per second $\left(\mathrm{ft}^{2} / \mathrm{s}\right)$, and 0.61 , respectively.

The water level $(h)$ varied through time as did the height of the opening, $b$, as noted in table $1-1$ and measured by the water level sensor. During the periods when gates 1 and 4 were not opened flow was not estimated through those gates.

For the overflow gates (gates 2 and 3), the flow was estimated using a sharp-crested weir equation (Rouse and Howe, 1953) of the form:

$$
Q=\frac{2}{3} C_{d} \sqrt{2 g L h \frac{3}{2}}
$$

where

$$
\begin{aligned}
Q & \text { is streamflow, } \\
C_{d} & \text { is the discharge coefficient, } \\
g & \text { is the gravitational constant in square feet per } \\
& \text { second, } \\
L & \text { is the width of the gate, and } \\
h & \text { is the head (water level) measured above top } \\
& \text { of the weir. }
\end{aligned}
$$

The coefficients $C_{d}, L$, and $g$ are held constant at $0.652,5 \mathrm{ft}$, and $32.17 \mathrm{ft}^{2} / \mathrm{s}$, respectively. Only the water level above the weir, $h$, varied through time. Any additional flow that may go over the crest of the dam, if the water level in the impoundment should rise high enough, was estimated using the same weir equation only using the width from the various five different crest segments (Crests 1-5; fig. 1-1).
Lastly, the streamflow going past the Silver Lake dam was measured 15 times during this study to assist in calibrating the developed rating. The individual streamflow measurements can be obtained from http://waterdata.usgs.gov/mi/ nwis/measurements/?site_no $=04122211 \&$ agency_cd=USGS. Streamflow measurements were only made during periods where the overflow gate boards were manipulated, so events where sluice gates were manipulated were not measured. Initially, the comparison of the rated discharge to the measured discharge was poor. However the discharge coefficient, $C_{d}$, was adjusted to find the best fit between the rated and measured streamflow (fig. 1-2). The discharge coefficient that provided the best fit between the rated and measured streamflow was 0.652 . The linear best-fit line produced an R-squared of 0.969 , which indicates good correlation between the rated and measured streamflow estimate.

\section{References Cited}

National Geodetic Survey, 2003, Orthometric Height Conversion Tool, accessed March 17, 2015, at http://www.ngs. noaa.gov/cgi-bin/VERTCON/vert_con.prl.

Rouse, Hunter, and Howe, J.W., 1953, Basic mechanics of fluids: New York, Wiley, 245 p. 


\section{Appendix 2. Additional Data Collected}

\section{Bioassay Study-Microcystin and Phytoplankton}

\section{Laboratory Analysis}

Intercellular microcystin concentrations were determined by liquid chromatography-mass spectrometry (LC-MS) after an extraction process involving both a freeze-thaw step and lyophilization to lyse the algal cells (Fastner and others, 1998). A five-point calibration curve with internal standard addition was used to determine final concentrations of the two primary forms of microcystin: microcystin LR and microcystin RR; these were summed to estimate total microcystin.

Identification and enumeration of phytoplankton samples were done in a Palmer-Maloney counting chamber ( 0.1 milliliter [mL]) at $400 \times$ magnification with a Leica DM LB2 compound microscope. A total of 300 algal units (cells, filaments, or colonies) were counted and identified to the lowest possible taxonomic level. The biovolume of dominant taxa (that is, all taxa that composed greater than 5 percent of the biovolume in an individual sample) was estimated by measuring 10 individuals and applying the mathematical formulae for their appropriate geometric shape (Hillebrand and others, 1999). The biovolume of less abundant taxa was estimated using data from Steinman and others (2008). Only organisms with intact cell contents were included in the biovolume estimation. The standard operating procedure was modified for phytoplankton analysis (U.S. Environmental Protection Agency, 2010) to increase the likelihood that species forming large floating colonies (for example, Gloeotrichia) would be detected. Each concentrated sample was settled for at least 24 hours before all visible colonies of Gloeotrichia were counted with a magnifying glass. The sample also was examined for individual Gloeotrichia filaments, but they were not encountered. Ten colonies were transferred to a Palmer-Maloney counting cell and measured under the microscope to estimate colony size, number of filaments, and biovolume. In only 1 instance (1 sample from initial treatment) were less than 10 colonies found. The Gloeotrichia biovolume was then included in total phytoplankton biovolume computations for each treatment.

\section{Data Analysis}

One-way analysis of variance (ANOVA) was used to assess differences in phytoplankton biovolume among the five treatments in the bioassay study (initial, control, nitrogen, phosphorus, and nitrogen plus phosphorus) with four replicates each (except initial, $\mathrm{n}=3$ ). Test assumptions were verified by examining biovolume data for normal distribution and equal variance among treatments. Statistically significant $(\alpha=$ 0.05 ) results were further analyzed with Tukey Honest Significance Difference (HSD) test to identify significant differences between pairs of treatments (Tukey, 1949).
Nonmetric multidimensional scaling (NMDS) ordination was used to evaluate patterns in phytoplankton community structure due to nutrient treatment. NMDS used the BrayCurtis similarity coefficient as a distance measure (Bray and Curtis, 1957). To evaluate the goodness-of-fit between the calculated (plotted) and the actual (from the similarity matrix) distances among the samples, the stress value was estimated. A stress value less than 20 indicates a good ordination (Clarke, 1993). The NMDS function was specified to run with 20 random starts in search of optimal solution with the lowest stress value.

To test if treatments resulted in different species compositions, samples were analyzed with analysis of similarity (ANOSIM; Clarke, 1993). This method tests for significant differences between two or more groups using the rank order of the sample dissimilarity matrix. Dissimilarity values were calculated with the Bray-Curtis similarity coefficient. If two groups had very different species compositions, the dissimilarities between the groups would be larger than those within the groups. This was evaluated by the $\mathrm{R}$ statistic, which varies between -1 and 1 , with values close to 0 indicating random grouping. The statistical significance $(\alpha=0.05)$ of the R statistic was evaluated with 999 permutations. If there was a significant difference in the species composition among treatments, indicator species analysis (Dufrêne and Legendre, 1997) was performed to find the species most responsible for the differences. Indicator taxa were those that were more abundant and had a higher probability of occurrence in one particular treatment $(\alpha<0.05)$. These data analyses were performed in the $\mathrm{R}$ program for statistical computing (R Development Core Team, 2012).

Other differences in algal response to nutrient treatments were analyzed using ANOVA. Differences in chlorophyll $a$ concentration, microcystin concentration (RR, LR, total), and chlorophyll $a$-normalized microcystin concentration (RR, LR, total) were analyzed among treatments (control, nitrogen, phosphorus, nitrogen plus phosphorus). Chlorophyll $a$ concentrations were ln-transformed prior to analysis to meet assumptions of normality and equal variance. Normality was tested using the Shapiro-Wilk test and multiple pairwise comparisons were tested using Holm-Sidak Method. Statistical significance was determined by p-values less than 0.05 . Chlorophyll $a$ and microcystin analyses were performed using SigmaPlot (version 12.5 , Systat).

\section{Bioassay Study Results-Microcystin and Phytoplankton}

Microcystin concentrations were not significantly different among nutrient treatments and were similar to the initial values for all microcystin forms (RR, LR, total). The World 
Health Organization (WHO) has issued guidelines for recreational exposure, including a low probability of acute health effects when microcystin-LR concentration is $<10 \mu \mathrm{g} / \mathrm{L}$, moderate risk at 10-20 $\mu \mathrm{g} / \mathrm{L}$, high risk at $20-2,000 \mu \mathrm{g} / \mathrm{L}$, and very high risk at $>2,000 \mu \mathrm{g} / \mathrm{L}(\mathrm{WHO}, 2003)$.

In Silver Lake, all microcystin concentrations were well below the WHO low-risk guidance for recreational exposure and none exceeded the EPA drinking water advisory for adults. Microcystin-LR concentrations were $>0.3 \mu \mathrm{g} / \mathrm{L}$ in early June and from mid-August through early October, though it is highly unlikely that any person could ingest a sufficient volume of lake water to cause adverse health effects from microcystin at such low concentrations (Steinman and others, 2015). There is no indication that increased nitrogen or phosphorus inputs will trigger greater toxin production, at least during the summer when these studies were conducted.

Mean total phytoplankton biovolume was $35.57 \times 10^{6}$ cubic micrograms per milliliter $\left(\mu \mathrm{m}^{3} / \mathrm{mL}\right)$ per sample. On average, diatoms accounted for the greatest biovolume $\left(32.50 \times 10^{6} \mu \mathrm{m}^{3} / \mathrm{mL}\right)$, followed by cyanobacteria $\left(2.43 \times 10^{6} \mu \mathrm{m}^{3} / \mathrm{mL}\right)$, and chlorophytes $\left(0.34 \times 10^{6} \mu \mathrm{m}^{3} / \mathrm{mL}\right)$. Diatoms were the most dominant group in all treatments; they reached their highest numbers in the nitrogen plus phosphorus treatment $\left(56.34 \times 10^{6} \mu \mathrm{m}^{3} / \mathrm{mL}\right)$ and lowest numbers in the initial samples $\left(17.00 \times 10^{6} \mu \mathrm{m}^{3} / \mathrm{mL}\right)$. Cyanobacteria were the second most dominant group in the control treatment $\left(6.89 \times 10^{6} \mu \mathrm{m}^{3} / \mathrm{mL}\right)$ and the second least dominant in the initial samples $\left(0.21 \times 10^{6} \mu \mathrm{m}^{3} / \mathrm{mL}\right)$. Similar to diatoms, chlorophytes were most abundant in the nitrogen plus phosphorus treatment $\left(0.65 \times 10^{6} \mu \mathrm{m}^{3} / \mathrm{mL}\right)$ but least abundant in the phosphorus treatment $\left(0.19 \times 10^{6} \mu \mathrm{m}^{3} / \mathrm{mL}\right)$.
A total of 41 phytoplankton species was observed, which resulted in a sample richness of 15 species (range 10-19). The most diverse group were the chlorophytes (14 species), followed by diatoms and cyanobacteria (11 species each), dinoflagellates (2), chrysophytes (2), and 1 cryptophyte. On average, the control and phosphorus treatments had the least species richness (13 and 14, respectively), initial samples had 15 taxa, while nitrogen and nitrogen plus phosphorus had 16 taxa each. The control treatment had the highest Shannon and Simpson diversity indexes (4.0 and 3.2, respectively), while the nitrogen plus phosphorus treatment had the lowest diversity (2.5 and 1.9). Of the 10 most dominant taxa, 5 were diatoms, 4 were cyanobacteria, and 1 was a chlorophyte (table 3-1). Five phytoplankton species were found in all samples; they included two cyanobacteria (Anathece minutissima [W. West] Komárek, Kastovsky \& Jezberová and Gloeotrichia echinulata Richter) and three diatoms (Aulacoseira granulata [Ehrenberg] Simonsen, Aulacoseira islandica [O.Müller] Simonsen, and Fragilaria crotonensis Kitton). The three species with the highest mean biovolume were all chain-forming diatoms such as Aulacoseira granulata (Ehrenberg) Simonsen, Aulacoseira islandica (O.Müller) Simonsen, and Aulacoseira granulata var. angustissima (O.Müller) Simonsen (table 2-1). Although Gloeotrichia was observed in all samples, its overall biovolume was modest compared to the dominant phytoplankton in Silver Lake.

Similar to the chlorophyll $a$ results (fig. 10 in the main report), the nitrogen plus phosphorus treatment resulted in the greatest algal biovolume (fig. 2-1), although this difference was statistically different from only the initials (F-value 3.66, $\mathrm{p}$-value $<0.05$ ); high variance precluded significant differences

Table 2-1. Ten most abundant phytoplankton species based on frequency of occurrence.

$\left[\mu \mathrm{m}^{3} / \mathrm{mL}\right.$, cubic micrometers per milliliter]

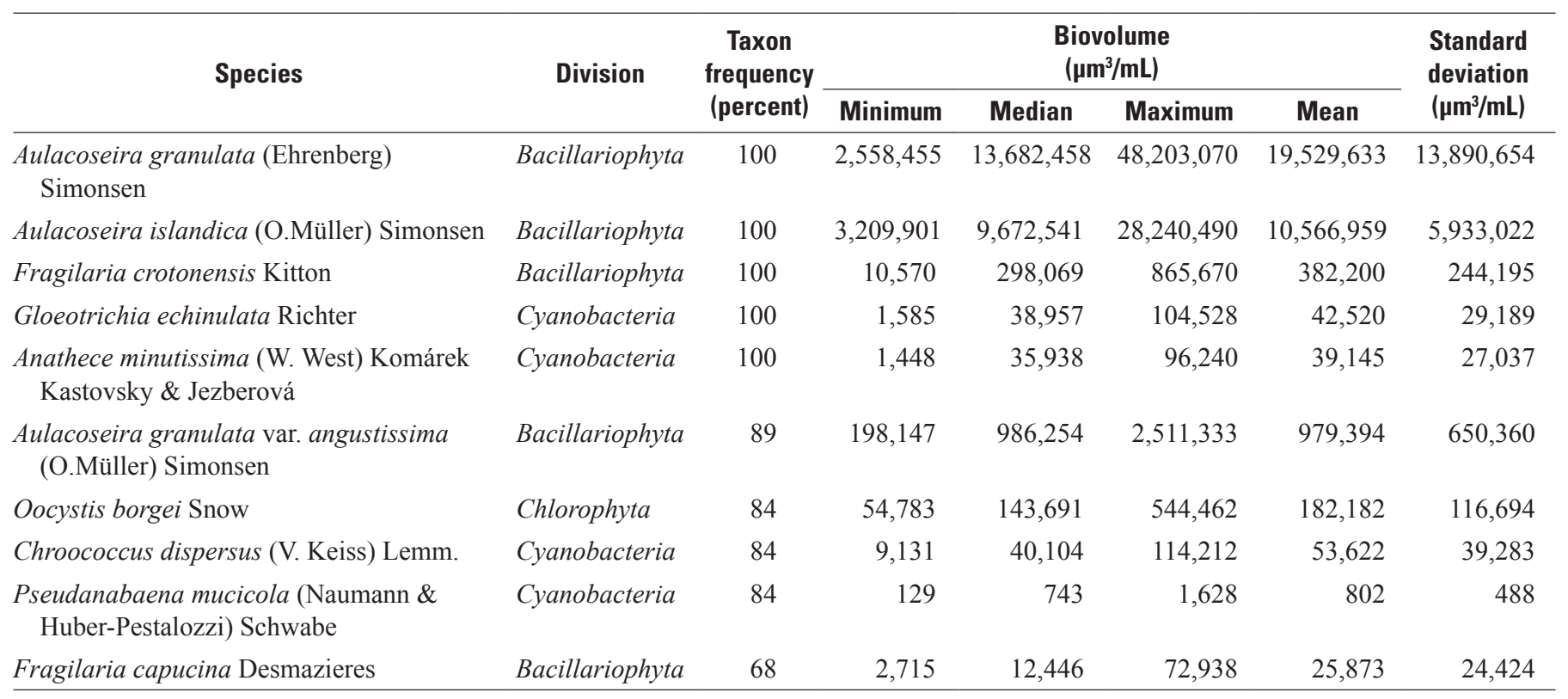




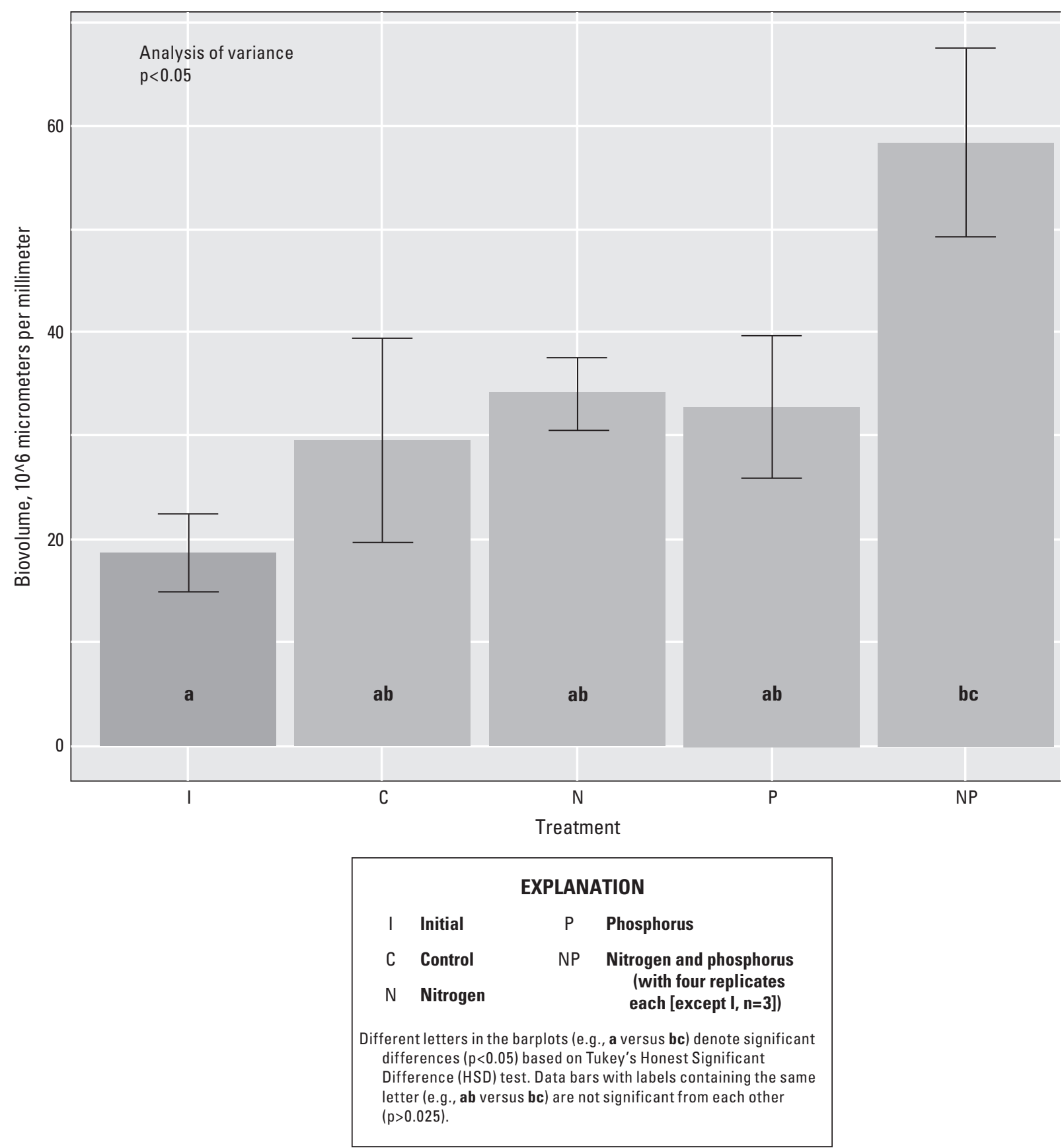

Figure 2-1. Barplots (mean plus 1 standard error) of phytoplankton biovolume in Silver Lake, Oceana County, Michigan, for five nutrient treatments.

between the nitrogen plus phosphorus versus the other treatments. Similarly, there were no significant differences among treatments in terms of Gloeotrichia biovolume, colony size and density, number of filaments per colony, filaments density, and biovolume. The same trend was observed for the dominant species. However, some of them exhibited differences among treatments and they included Aulacoseira granulata (significantly higher biovolume in the nitrogen plus phosphorus treatment), Chroococcus dispersus (significantly different biovolume between the control and phosphorus treatment), and Fragilaria capucina (significantly higher biovolume in nitrogen plus phosphorus treatment). Microcystis aeruginosa also exhibited differences among treatments (significantly different biovolume between control and nitrogen plus phosphorus treatment). 


\section{E. coli Monitoring}

\section{Laboratory Analysis}

Water samples collected from the tributaries, lake, and groundwater sampling locations were tested for Escherichia coli (E. coli) concentrations using the IDEXX 24-hour Colilert most probable number (MPN) method (IDEXX, 2013). E. coli samples were collected and stored away from sunlight and on ice for transport to the Michigan Bacteriological Research Laboratory at the U.S. Geological Survey (USGS), Michigan Water Science Center, Lansing, Michigan, where the samples were then analyzed. Samples were stored on ice for no longer than 60 hours prior to analysis.

\section{Results}

E. coli concentrations (MPN/100 milliliters [mL]) analyzed at each of the lake sites ranged from less than 1 (nondetect) to $7 \mathrm{MPN} / 100 \mathrm{~mL}$. The State of Michigan recreational criteria for $E$. coli is a daily geometric mean below $300 E$. coli $/ 100 \mathrm{~mL}$ for recreational activities such as swimming and snorkeling (total-body contact). The E. coli concentrations on Silver Lake measured as part of this study were far below the State's recreational criteria guidelines; however, it should be noted that the holding time of 60 hours exceeded the regulatory holding time set by the State for E. coli (6 hours).

E. coli concentrations at Hunter Creek ranged from 24 to $1,000 \mathrm{MPN} / 100 \mathrm{~mL}$ with a mean concentration of $250 \mathrm{MPN} / 100 \mathrm{~mL}$. E. coli concentrations at Hunter Creek exceeded the daily standard of $300 \mathrm{E}$. coli $100 \mathrm{~mL}$ on three occasions, two of which were during storm events. E. coli concentrations at the tributary at State Park ranged from 6 to $1,400 \mathrm{MPN} / 100 \mathrm{~mL}$, with an average concentration of $240 \mathrm{MPN} / 100 \mathrm{~mL}$; the highest concentrations were recorded during storm events. For the tributary at North Shore Drive, E. coli concentrations ranged from 8 to $1,600 \mathrm{MPN} / 100 \mathrm{~mL}$, with a mean of $352 \mathrm{MPN} / 100 \mathrm{~mL}$, which is in exceedance of the State E. coli criterion of 300 E. coli $100 \mathrm{~mL}$.

$E$. coli concentrations were measured quarterly at the groundwater wells, and E. coli was not detected in any of the samples collected (indicated by less than $1 \mathrm{MPN} / 100 \mathrm{~mL}$ ). The E. coli concentrations from the drain tiles at the north end of Silver Lake were consistently low, and averaged approximately $6 M P N / 100 \mathrm{~mL}$.

\section{Suspended-Sediment Concentrations}

Suspended-sediment concentrations (SSC) collected at Hunter Creek were typically low and ranged from 4 to 13 milligrams per liter $(\mathrm{mg} / \mathrm{L})$, and averaged $8 \mathrm{mg} / \mathrm{L}$ during the study period. SSC typically increased during storm events in Hunter Creek. SSC concentrations at the tributary at State Park and the tributary at North Shore Drive ranged from 5 to $155 \mathrm{mg} / \mathrm{L}$ and 8 to $33 \mathrm{mg} / \mathrm{L}$, respectively.

\section{References Cited}

Bray, J.R., and Curtis, J.T., 1957, An ordination of the upland forest communities of southern Wisconsin: Ecological Monographs, v. 27, no. 4, p. 151-164.

Clarke, K.R., 1993, Non-parametric multivariate analysis of changes in community structure: Australian Journal of Ecology, v. 18, no. 1, p. 117-143.

Dufrêne, Marc, and Legendre, Pierre, 1997, Species assemblages and indicator species-The need for a flexible asymmetrical approach: Ecological Monographs, v. 67, no. 3, p. 345-366.

Fastner, Jutta; Flieger, Inge; and Neumann, Uwe, 1998, Optimised extraction of microcystins from field samplesA comparison of different solvents and procedures: Water Research, v. 32, no. 10, p. 3177-3181.

Hillebrand, Helmut; Dürselen, Claus-Dieter; Kirschtel, David; Pollingher, Utsa; and Zohary, Tamar, 1999, Biovolume calculation for pelagic and benthic microalgae: Journal of Phycology, v. 35, no. 2, p. 403-424.

IDEXX Laboratories, Inc., 2013, Instruction manuals for use of Colilert ${ }^{\circledR}$, Quanti-Tray ${ }^{\circledR} / 2000$, and Quanti-Tray Sealer ${ }^{\circledR}$, accessed August 6, 2015, at https://www.idexx.com/water/ water-testing-solutions.html.

R Development Core Team, 2012, R-A language and environment for statistical computing: Vienna, Austria, R Foundation for Statistical Computing, accessed August 6, 2015, at http://www.R-project.org.

Steinman, A.D., Ogdahl, Mary, and Gillett, Nadia, 2015, An analysis of the cyanobacterium Gloeotrichia in Silver Lake: Grand Valley State University, Annis Water Resources Institute and Portland State University, 36 p.

Steinman, A.D., Ogdahl, Mary, Rediske, Richard, Ruetz, C.R., III, Biddanda, B.A., and Nemeth., Lori, 2008, Current status and trends in Muskegon Lake, Michigan: Journal of Great Lakes Research, v. 34, no. 1, p. 169-188.

Tukey, J.W., 1949, Comparing individual means in the analysis of variance: International Biometric Society , Biometrics, v. 5, no. 2, p. 99-114.

U.S. Environmental Protection Agency, 2010, Standard operating procedure for phytoplankton analysis (rev. 05): accessed August 6, 2015, at, http://www.epa.gov/greatlakes/monitoring/sop/chapter_4/lg401.pdf.

World Health Organization (WHO), 2003, Guidelines for safe recreational water environments, Volume 1, Coastal and fresh waters: Geneva, World Health Organization, 219 p. 


\section{Appendix 3. Quantification of Groundwater Flow to Silver Lake}

The groundwater flow to Silver Lake was characterized on the basis of water levels measured at the four shallow wells around the lake, discrete seepage meters, and discrete groundwater temperature data. Water levels were monitored continuously in the wells on the east and west side of Silver Lake and discretely on the north and south side of Silver Lake (fig. 3-1).

These water levels were used in conjunction with the lake stage estimated near Hunter Creek (0412220999) to estimate groundwater flux using the Dupuit equation (Rosenberry and LaBaugh, 2008). The Dupuit equation for an unconfined aquifer is defined as

$$
Q=K m \frac{\left(h_{1}^{2}-h_{2}^{2}\right)}{2 L}
$$

where

$$
\begin{aligned}
& K \quad \text { is horizontal hydraulic conductivity in meters } \\
& \text { per day, } \\
& m \quad \text { is length of shoreline in meters, } \\
& L \quad \text { is distance from piezometer to lake shore in } \\
& \text { meters, } \\
& h_{1} \quad \text { is saturated aquifer thickness at the } \\
& \text { piezometer, and } \\
& h_{2} \quad \text { is aquifer thickness at the edge of the surface- } \\
& \quad \text { water body. }
\end{aligned}
$$

The hydraulic conductivity for the unconfined aquifer adjacent to and below Silver Lake was estimated at 7 feet per day (ft/d) based on information from the Michigan Groundwater Mapping Project (2006) map viewer. The length of shoreline was split up into four quadrants around the lake as shown in figure 3-2 such that each quadrant corresponded to a piezometer. The length of shoreline by cardinal direction was $3,809,5,485,5,187$, and 7,949 feet (ft) for the north, east, south, and west shorelines, respectively. The distance from the piezometer to the lakeshore varied as the water level in the lake varied, but, on average, the distance was $12,38.4$, 8 , and $24 \mathrm{ft}$, for the north, east, south, and west quadrants, respectively.

The effective thickness of the aquifer was estimated assuming that the base of the aquifer contributing water was approximately the maximum depth of the lake which was $22 \mathrm{ft}$ (Groves and others, 2013). Assuming a mean lake surface elevation of $586 \mathrm{ft}$, puts the base of the aquifer elevation at approximately $564 \mathrm{ft}$. The aquifer thickness, $\mathrm{h}_{1}$ for each piezometer was estimated by subtracting $564 \mathrm{ft}$ from the water level elevation measured in the piezometer. The aquifer thickness at the edge of the surface water body, $h_{2}$ was estimated by subtracting $564 \mathrm{ft}$ from the elevation for the lake stage estimated from the Hunter Creek streamgage. In order to get a daily estimate of flux for the piezometers with only discrete water-level elevation measurements, a correction factor was applied to the west piezometer water-level record to get the continuous water-level record to correspond to the discrete measurements at those wells. The factor applied was $0.2 \mathrm{ft}$ for the north piezometer and $0.22 \mathrm{ft}$ for the south piezometer. Solving the Dupuit equation for using the piezometer waterlevel data from October 1, 2013, to September 30, 2014, yields a total flux of $2.16 \times 10^{7}$ cubic feet $\left(\mathrm{ft}^{3}\right)$. Comparison of the Dupuit groundwater-flux estimate to the groundwaterflux estimate from the water-balance compilation (Sources of Water-Water Budget section), derived as the difference between the inflows and outflows $\left(2.27 \times 10^{8} \mathrm{ft}^{3}\right)$, indicated that some assumptions in the Dupuit estimate were likely wrong. Possibilities for error include, but are not limited to, using incorrect hydraulic conductivity estimates for the aquifer, inaccurate representation of the effective aquifer thickness, incomplete data for water year 2013 limiting the period for estimates to 2014, and an inability to represent water-level variability around the lake with the four water-level monitoring points available. A water year is the 12 -month period October 1 through September 30 designated by the calendar year in which it ends.

As a result of the complexities with using the Dupuit estimate, a different approach to estimating the groundwater discharge to the lake was attempted. Discrete seepage meters (Rosenberry and LaBaugh, 2008) were deployed at 18 locations around Silver Lake (fig. 3-2). The seepage meter consists of a 2.69 square feet $\left(\mathrm{ft}^{2}\right)$ cutoff barrel that is attached to a bag containing a known volume of water sheltered in a plastic enclosure. The plastic enclosure helps protect the bag from effects of waves or flowing water from affecting the volume of water entering or leaving the bag. The procedure used for operating the seepage meters is outlined in Rosenberry and LaBaugh (2008). For this investigation, three individual seepage measurements were collected at each site and the mean value of those measurements was used as the seepage rate estimate for that site. Results of the seepage survey indicate that the seepage rates vary from $4.86 \times 10^{-8}$ feet per second (ft/s) to $1.52 \times 10^{-5} \mathrm{ft} / \mathrm{s}$ with a mean value of $3.00 \times 10^{-6} \mathrm{ft} / \mathrm{s}$; note that seepage measured from the seepage meters was seepage from the groundwater to the lake.

In addition to seepage meters, discrete temperature sensor arrays were deployed to estimate groundwater flux at several locations around Silver Lake. This was done to both confirm the seepage meter derived groundwater discharge estimate and identify any temporal variability in groundwater flow to the lake. The temperature array used for this investigation consisted of a wooden stake with four temperature sensors inserted in the stake at 3.9-inch (in.) intervals. The temperature sensors used in this study were iButton thermal data loggers (Maxim Integrated DS1922L), which were operated at a thermal precision of 0.0625 degrees Celsius $\left({ }^{\circ} \mathrm{C}\right)$. The stake was then driven into the lakebed sediment such that a temperature sensor was located just below the sediment water 


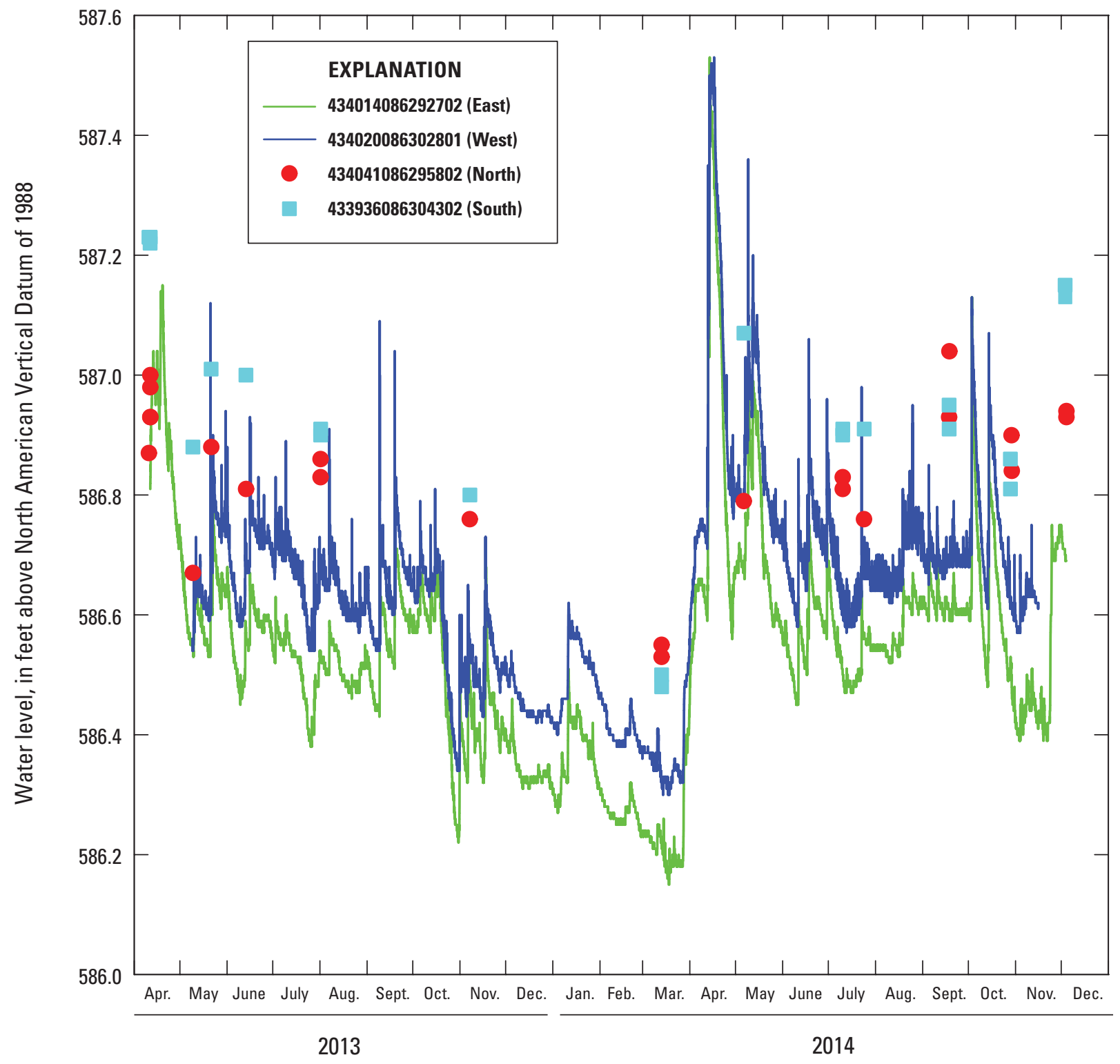

Figure 3-1. Continuous and discrete water-level elevations for the shallow wells around Silver Lake, Oceana County, Michigan, April 2013-December 2014.

interface defined as 0 inches (in.), 3.9 in. below the lakebed, $7.9 \mathrm{in}$. below the lakebed, and $11.8 \mathrm{in}$. below the lakebed.

The temperature was then recorded every 20 minutes at each sensor while the array was deployed. The wooden stakes were then recovered and the data downloaded from each sensor for analysis. The temperature sensors were deployed at five locations around Silver Lake from July 23 to September 18, 2014. However, only two sensor arrays on the north and east sides of the lake were recovered. It is suspected that wave action and (or) anthropogenic activity removed the others. Two sensor arrays were deployed again in October 2014 at locations on the west side of the lake and the south side of the lake. Only the south sensor array was recovered in November, and again the west sensor array was not recovered due to suspected wave or anthropogenic activity.
Analysis of the temperature data was performed using 1DTempPro (Voytek and others, 2013), which is a graphical user interface for VS2DH (Healy and Ronan, 1996). 1DTempPro formats the user-supplied groundwater temperature data for VS2DH to solve a one-dimensional finite-difference solution to the groundwater-flow and heat transport equation. The program then sets up a grid of 3 columns with 103 rows, each 39.4 in. wide and 0.114 in. deep. The first and third columns establish no-flow boundaries and the central column represents a vertical section between 0 and 11.8 in. deep in the lakebed. Sensitivity of the groundwater flux estimates to the cells size was not determined for this study. Specified temperature boundaries were applied to the top and bottom cells of the model which correspond to the data collected at the top ( 0 in.) and bottom (11.8 in.) sensor of the temperature array. 


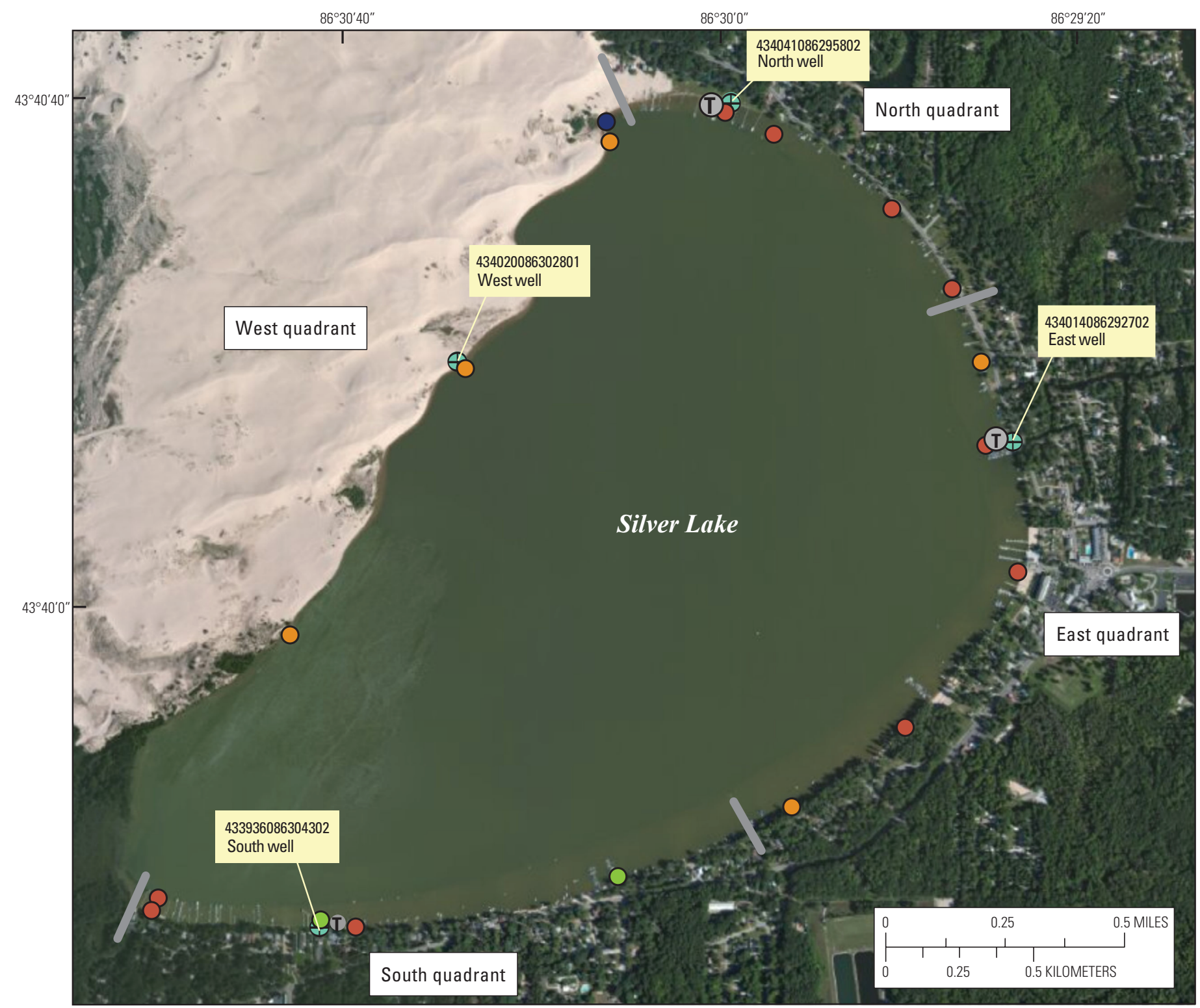

Source: Esri, Digital Globe GeoEye, i-cubed, USDA, USGS, AEX, Getmapping, Aerogrid, IGNIGP, swisstopo, and the GIS User Community

\section{EXPLANATION}

\begin{tabular}{|c|c|}
\hline Seepage, in feet per second & Temperature sensor array \\
\hline $4.86 \times 10^{-8}-2.21 \times 10^{-6}$ & $\begin{array}{c}\text { deployment } \\
\text { Monitoring well location }\end{array}$ \\
\hline $2.22 \times 10^{-6}-4.36 \times 10^{-6}$ & Quadrant divider \\
\hline $4.37 \times 10^{-6}-6.52 \times 10^{-6}$ & \\
\hline $6.53 \times 10^{-6}-8.68 \times 10^{-6}$ & \\
\hline $8.69 \times 10^{-6}-1.08 \times 10^{-5}$ & \\
\hline $1.09 \times 10^{-5}-1.30 \times 10^{-5}$ & \\
\hline $1.31 \times 10^{-8}-1.52 \times 10^{-5}$ & \\
\hline
\end{tabular}

Figure 3-2. Locations of wells, seepage meters, and temperature sensor array deployments around Silver Lake, Oceana County, Michigan. 
These temperature boundaries were time-varying as they represent the temperature over the duration of time that the array was deployed. There were no external stresses (for example, pumping) applied to the model. To analyze the groundwater flow to Silver Lake, temperature data from each sensor array was downloaded and merged into one input file for 1DTempPro. The data were then loaded into 1DTempPro and simulated using the following parameters for each site; porosity of 0.33 , thermal conductivity of $2.3 \frac{\mathrm{W}}{\mathrm{m}^{\circ} \mathrm{C}}$ (where $W$ is watts, $m$ is meters and $C$ is Celsius), dispersivity of $0.328 \mathrm{ft}$, and sediment heat capacity of $2.50 \times 10^{6} \frac{J}{m^{3 \circ} \mathrm{C}}$ (where $J$ is Joules, $m$ is meters and $C$ is Celsius). These parameters are within the range of values for coarse-grained sediment like the dune sands found at Silver Lake (Lapham, 1989). The model was calibrated by adjusting the estimated groundwater discharge until the simulated temperature signal matched the observed temperature signal. Figure 2-3 indicates an accurate fit with high coefficient of determination $\left(\mathrm{R}^{2}\right)$ ranging from 0.971 to 0.998 , and low root mean square error (RMSE) of estimated temperature ranging from 0.041 to $0.231^{\circ} \mathrm{C}$. Note that only the 3.9 and $7.9 \mathrm{in}$. depth temperature signals were calibrated to, as the 0 and 11.8 in. depth temperature signals serve as boundary conditions in the model. These boundary conditions are forced to match the observed temperature and are not appropriate to include in the simulated to observed value comparison.

Limitations of using 1DTempPro for estimating groundwater fluxes to Silver Lake include but are not limited to: assuming that all flow to and from the lakebed is entirely vertical or 1-dimensional, and that all hydraulic and thermal properties of the lakebed are homogenous and isotropic. If the flow over the length of lakebed studied was more 2-dimensional, the 1-dimensional approximation might not accurately represent the flux. Similarly, heterogeneity in the physical and thermal characteristics of the lake bed sediment may cause some uncertainty in the flux estimate. However, for the very short flow distance that was examined (11.8 in.), these assumptions appear to be valid given the low error between simulated and observed temperatures.

The estimated groundwater discharge for the north array was very low, $1.8 \times 10^{-6} \mathrm{ft} / \mathrm{s}$ and indicated that the lake was discharging water into the aquifer. The estimated groundwater discharge for the east array was also quite low, $1.46 \times 10^{-6} \mathrm{ft} / \mathrm{s}$, but indicated groundwater was discharging to Silver Lake. These low estimates can be classified as circum-neutral, less than $3.28 \times 10^{-6} \mathrm{ft} / \mathrm{s}$ (Lautz, 2012), or essentially that they are so low that they cannot effectively be differentiated from a noflow condition using the temperature profiling approach. The estimate of groundwater discharge for the south array indicates discharge from the aquifer to the lake at a rate of $3.17 \times 10^{-5} \mathrm{ft} / \mathrm{s}$, which is slightly higher than that measured by the discrete seepage meter near that location $\left(8.23 \times 10^{-6} \mathrm{ft} / \mathrm{s}\right)$. Although the values are slightly different, they agree in general magnitude. Additionally, the rate of discharge for the period that was measured (October 29 to November 17, 2014) remained fairly constant which indicates that groundwater discharge to the lake did not vary greatly over short time scales.
On the basis of the seepage meter estimates and temperature sensor data, a new approach was taken to allocating groundwater discharge to Silver Lake. Rather than independently estimate the total groundwater discharge to Silver Lake, the residual between the inflows and outflows of the water balance were used to estimate the total groundwater discharge to the lake. This total value was then proportionally divided amongst the four quadrants (fig. 3-2) using a proportion factor developed from the seepage meter estimates. This factor was defined as the mean seepage by each quadrant, multiplied by the length of shoreline in the quadrant and then divided by the sum of that product for all quadrants. The result was a proportion of flow by quadrant, which for Silver Lake was 2.7, 10.9, 25.0, and 61.4 percent for the north, east, south, and west quadrants, respectively. Those proportion factors were applied to the total volume of groundwater flow estimated from the water balance analysis to develop the flow estimates used in the BATHTUB model for estimating the nutrient load from groundwater sources.

The flow estimates derived from the procedure outlined above were then compared to the discrete seepage measurements to ensure that the average value was a reasonable magnitude. This was done by dividing the volume of groundwater flow for each quadrant by the number of seconds in the study period $(63,072,000)$, the length of shoreline for the respective quadrants, and a characteristic leakage length. The characteristic leakage length, termed lambda, is defined as $=\sqrt{T c}$, where $T$ is the aquifer transmissivity and $c$ is the resistance between the groundwater and surface water feature (Hunt and others, 2003). It has been observed that approximately 95 percent of the leakage into a lake occurs within three times this characteristic leakage length lambda (Hunt and others, 2003). To estimate the characteristic leakage length $\lambda$, the transmissivity $(T)$, defined as the aquifer thickness multiplied by the hydraulic conductivity of the aquifer and the resistance $(c)$, defined as thickness of the lakebed layer divided by the vertical $\mathrm{k}$ of the layer had to be estimated. The $T$ estimate was based on an assumed thickness of $22 \mathrm{ft}$ based on the lake depth as well as hydraulic conductivity of $7 \mathrm{ft} / \mathrm{d}$, which yields 154 square feet per day $\left(\mathrm{ft}^{2} / \mathrm{d}\right)$. The $c$ estimate was based on an assumed lakebed thickness of $1.5 \mathrm{ft}$ and a vertical hydraulic conductivity of $0.7 \mathrm{ft} / \mathrm{d}$, which yields 2.14 days. The square root of the product of $\mathrm{T}$ and $\mathrm{c}$ yields a $\lambda$ of $18.2 \mathrm{ft}$. Taking the volumetric flow of water by quadrant for the 2-year study and dividing by the number of seconds in the study, the length of shoreline, and three times the characteristic length $(\lambda)$ yields an average flux rate of $9.25 \times 10^{-7} \mathrm{ft} / \mathrm{s}, 2.64 \times 10^{-6} \mathrm{ft} / \mathrm{s}$, $6.38 \times 10^{-6} \mathrm{ft} / \mathrm{s}$, and $1.02 \times 10^{-5} \mathrm{ft} / \mathrm{s}$ for the north, east, south and west quadrants, respectively. This compares well to the average rate of seepage by quadrant determined from the seepage meter survey $5.58 \times 10^{-7} \mathrm{ft} / \mathrm{s}, 1.60 \times 10^{-6} \mathrm{ft} / \mathrm{s}, 3.85 \times 10^{-6} \mathrm{ft} / \mathrm{s}$, $6.20 \times 10^{-6} \mathrm{ft} / \mathrm{s}$ for the north, east, south, and west quadrants, respectively. The agreement in these numbers further supports the estimates of groundwater flow to Silver Lake derived from the procedure outlined in this appendix (fig. 3-3). 

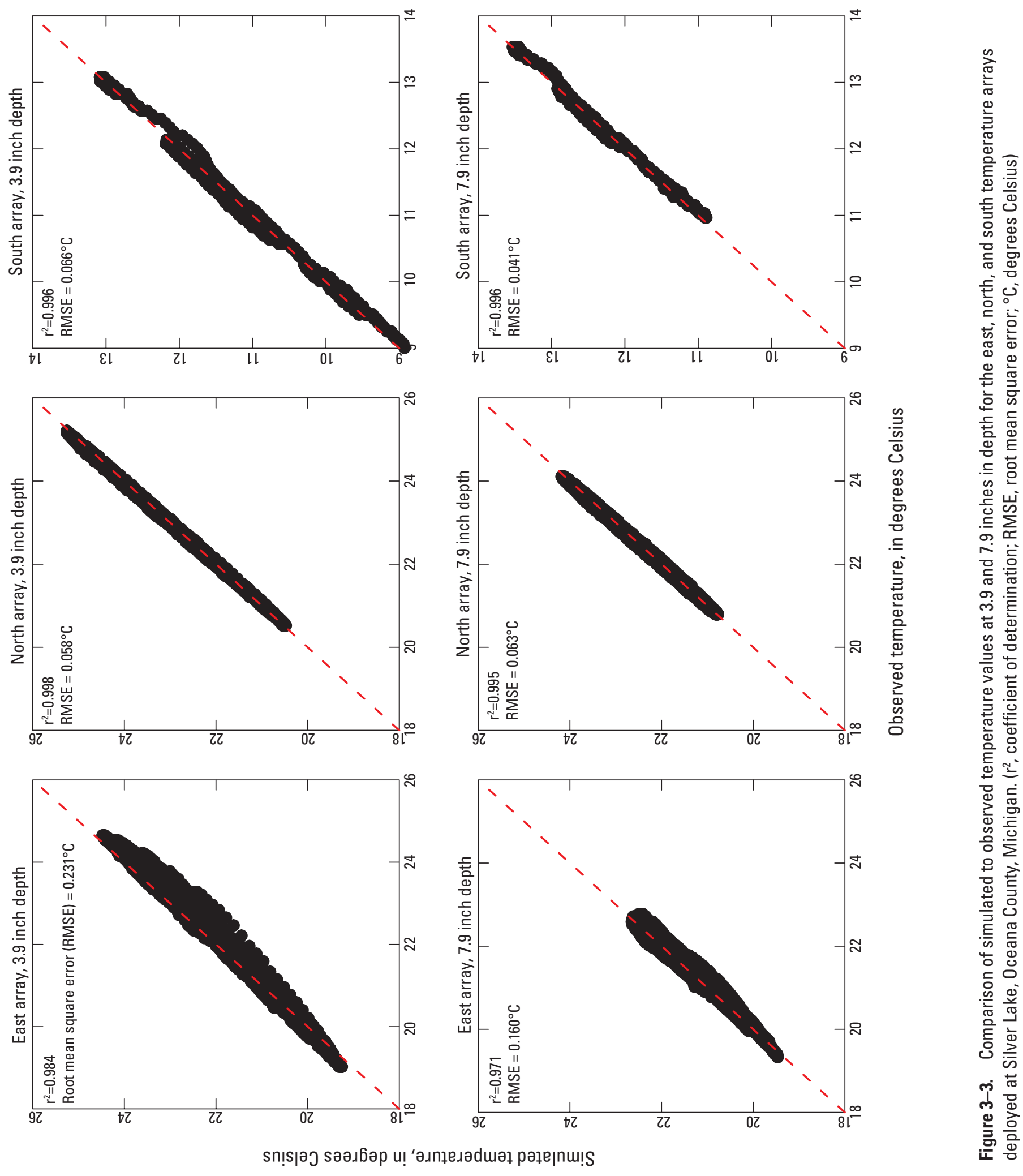


\section{References Cited}

Healy, R.W., and Ronan, A.D., 1996, Documentation of computer program VS2DH for simulation of energy transport in variably saturated porous media-Modification of the U.S. Geological Survey's computer program VS2DT: U.S. Geological Survey Water-Resources Investigation Report 96-4230, $36 \mathrm{p}$.

Hunt, R.J., Haitjema, H.M., Krohelski, J.T., and Feinstein, D.T., 2003, Simulating ground water-lake interactions: Approaches and insights: Ground Water, v. 41, no. 2, p. 227-237.

Lapham, W.W., 1989, Use of temperature profiles beneath streams to determine rates of vertical ground-water flow and vertical hydraulic conductivity: U.S. Geological Survey Water-Supply Paper 2337, 35 p.
Lautz, L.K., 2012, Observing temporal patterns of vertical flux through streambed sediments using time-series analysis of temperature records: Journal of Hydrology, v. 464-465, p. 199-215.

Michigan Groundwater Mapping Project Web Site, 2006, accessed October 31, 2014, at http:/gwmap.rsgis.msu.edu/.

Voytek, E.B., Drenkelfuss, Anja, Day-Lewis, F.D., Healy, Richard, Lane, J.W., and Werkema, Dale, 2013, 1DTempPro-Analyzing temperature profiles for groundwater/ surface-water exchange: Ground Water, v. 52, no. 2, p. 298-302. 


